University of Louisville

ThinkIR: The University of Louisville's Institutional Repository

Electronic Theses and Dissertations

1942

\title{
A study of apportionment in Indiana.
}

Stannard Kinneth Short 1911-1977

University of Louisville

Follow this and additional works at: https://ir.library.louisville.edu/etd

Part of the American Politics Commons, and the Public Administration Commons

\section{Recommended Citation}

Short, Stannard Kinneth 1911-1977, "A study of apportionment in Indiana." (1942). Electronic Theses and Dissertations. Paper 1893.

https://doi.org/10.18297/etd/1893

This Master's Thesis is brought to you for free and open access by ThinkIR: The University of Louisville's Institutional Repository. It has been accepted for inclusion in Electronic Theses and Dissertations by an authorized administrator of ThinkIR: The University of Louisville's Institutional Repository. This title appears here courtesy of the author, who has retained all other copyrights. For more information, please contact thinkir@louisville.edu. 
A BTUDY OF APPOKTIONMEN I IHDTAMA

\author{
A Diseertation \\ Subeittod to the Faculty \\ of the Gradunte school of the Unlversity of Loulaville \\ In Partial Fulridiment of tho \\ Requil romente for the Degree \\ or Master of Arte
}

Depertment of Polltioel Solonoe

by

Stannard Kinneth Short

year

1942 
INS OF 8T0Dmix, Btannard Xinnoth short

TIFL of THESIs, 4 8tudy of Apportlement in Indiven

APPROVED BY READIMC COMATYTEE COUPOBED OF THE

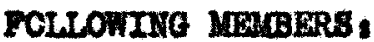

Chairmon

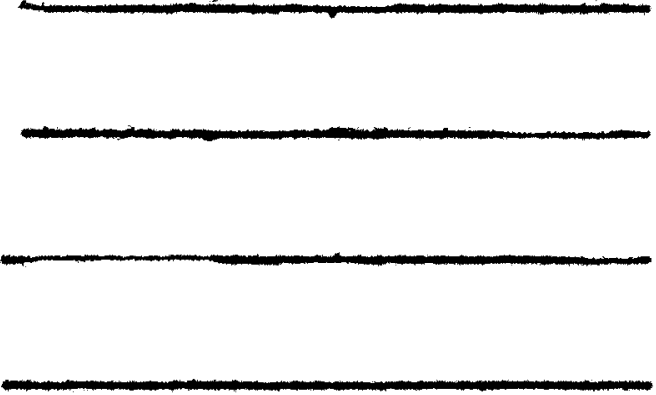

MUE OP DIRECTOR:

DATE: OAP.21942 


\section{FORETOFD}

Thle examination of the cinditiona reletive to apportionment in the stete of Indiene is not an attempt to prove or disprove any oonditione. This investigetion purporte to reveal the ectuel conditions and to examine and to bring to 11 ght all of the factore 1 nvolved in the question of representetion in the state of Indiana. Should any conolusions be drown, the frcts whioh support those oonelusione w1I be olemrly polnted out. There Is no intention on the part of the author to atert with the assumption thet there is angthing wrong with the agatem as it now atends. On tho other hend the fects and Ilgurea 121 be wo presented and arranged thet ahould ang peraon or geney oare to use then they might we11 bo emplojed as besls for furthor study or as an old toward better and more democratio government in the state of Indienc.

The one besic aevuption of this work, hovever, 1s that the leglaleture most folrly repreanting the population in terms of numbers is moat demooratio. With thet thought in wind we preasent this study. 
TABLE OF CONTEMTS

Chepter

Page

I History of Apportioment in Indiana el nee 1815. I

II Bxiating Conditions.

A. Const1 tuti onal Ifint tati ons.

B. Exami nation of the Law of 1021 .

C. Shlfts in Population since 1981.

D. Urban ve. Rural.

E. Polltiani Implication.

III Proposele for Redistmoting the state at the 80 prosent time.

IV Appondix A. Tablos Rolativo to Population and 64 Partios.

Appendix B. Lats Apportioning the state for Ioglalative Purposes.

$\boldsymbol{8}$

v Blbllography. 


\section{IISP OF MAPS}

number

1. Indi ana count1os in $1815 \ldots \ldots \ldots \ldots \ldots \ldots \ldots \ldots$

2. Indiane Countion in $1833 \ldots \ldots \ldots \ldots \ldots \ldots \ldots$

3. Indi ana count1or in $1858 \ldots \ldots \ldots \ldots \ldots$

4. Indi ana senatorlal Apport1oment uep.....30

5. Indi an Representati ve Apporti onment

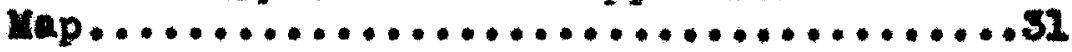

6. Indina Congressional Apportionment uap...............................32

7. Senntorial DIstriots in Thioh a senator Represents 10 es than the state Quota.....36

8. Count1es hering $\mathbf{3 7 \%}$ of Population, but

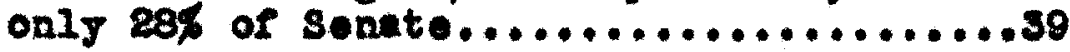

9. Countios having more than 100 people par square m116....................41

10. Republioan Count1es in 1934 and $1938 \ldots \ldots 44$

11. Domoerat1o Countios in 1934 and $1938 \ldots \ldots 45$

12. Demooratio Counties in 1934 and 1938 that have gal nod more than 5.900 sino $1920 \ldots .47$

13. Republican Counties in 1934 and 1938 that have gained more than 5,000 sinos $1020 . .48$

14. Proposed senatorial Rodiatrioting Plan $\mathbf{A . 5 3}$

15. Proposed Representative Redistrioting

Plan $4 \ldots \ldots \ldots \ldots \ldots \ldots \ldots \ldots \ldots \ldots \ldots \ldots \ldots \ldots \ldots \ldots \ldots$ 
CHAPTER I

HISTORY OF APPORTIOMMENT IN INDIAHA SIMCE 1815 


\section{CHAPTER I}

BISTORY OF APPORTIONMENT IN INDIAMA SIMCE 1816

By the formal "Act of Admissi on" of Deoumber 11 , 1816, the Congrass of the United States of America orested the state of Indiana. On April 3rd, 1816, while the Enabling Act was belng conaldered, Senetor Devid Daggett of Connootiout asked that the Comittee on rerritorl os acertaln the number of froe inhabitants in the territory. The next day Sonator Jeromiah Morrow of Oh10, the Chairman of this Committee, aubmitted cenaus report on the population of the territory of Indiana. This report showed the distribution of population in the following manner.

\begin{tabular}{|c|c|c|}
\hline Countr & Votere & Population \\
\hline 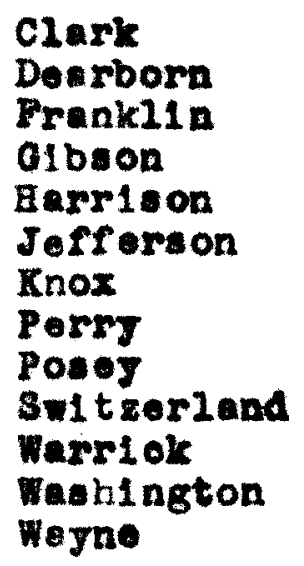 & $\begin{array}{r}1,387 \\
908 \\
1,430 \\
1,100 \\
1,056 \\
874 \\
1,391 \\
350 \\
320 \\
377 \\
880 \\
1,420 \\
1,225 \\
\end{array}$ & $\begin{array}{l}7,150 \\
4,424 \\
7,370 \\
5,330 \\
6,976 \\
4,270 \\
8,068 \\
1,780 \\
1,610 \\
1,828 \\
1,415 \\
7,317 \\
8,407 \\
\end{array}$ \\
\hline TOTAL & 12,112 & $63,387^{1}$ \\
\hline
\end{tabular}

1 Logen Banrey, A Hlatory of Indiane (Dajton Ohlo: Dayton H1storicaI Publishing (0.. (923), V01. 1. p. 249. 


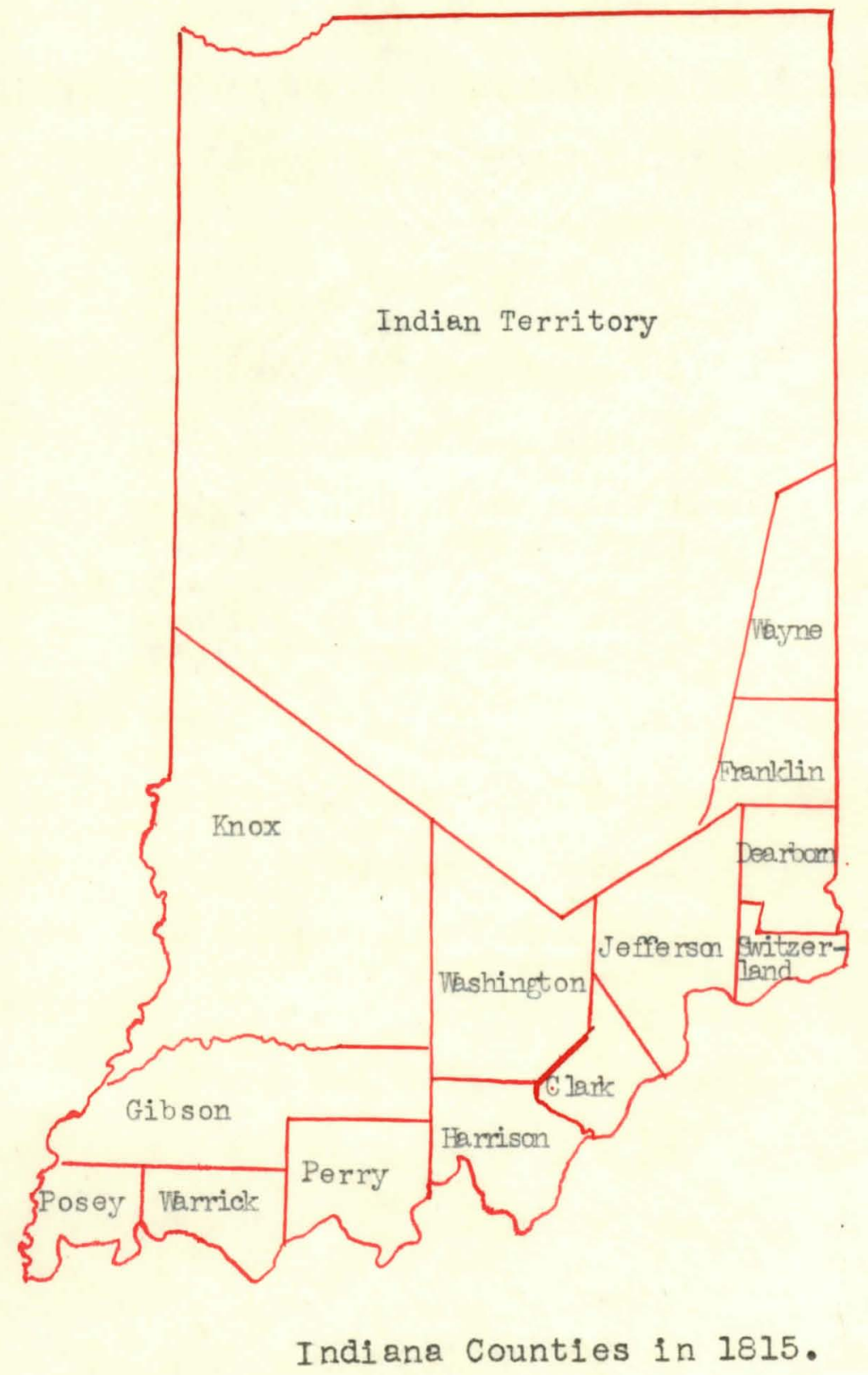


On the basis of this firat census report the Enabling let was passed and on April 18th was slgned by the Prosident. This Act sot May 13th as the day for the - leotion of delogates to conetitutionel conrention. The epportlonment of dolegates was as follows.

$$
\text { Countr Ho. or Delegater }
$$

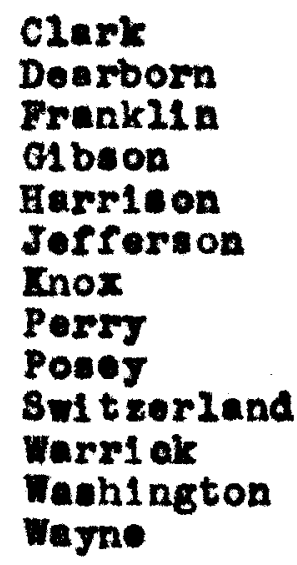

TOTAL

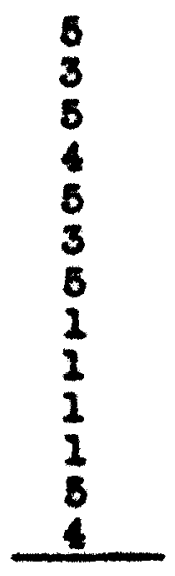

43

Thl convention was in sesel on from Monday, June 10th, until saturdey, June 28th, elghteen working daye. The convention mot at Corydon, Indiana, the old oep1tal. 1

Art1010 III of the Constitution that omanated from this convention dealt with the logitelative branch and was almost an exact copy of the Onio constitution. ${ }^{2}$

\footnotetext{
2 Ibld., Vol. 1, p. 248.

2 Indiane lot 1831, (Published by Stete of Indiana, 1831) Constitution of 1816, Articlo III.
} 
This Article creeted General Aasembly, composed of Senate and House of Representetives, both of which were elected by the people. The second section of this Article provided thet an enumertion wes to be taken within two years after the first meeting of the General Assombly. Thero was also to be an enumeration in 1820 , and additionel one was to be teken at the end of every subsequent period of five joers. This enumeretion was to be of the white mele inhabitents over twenty-one years of age.

The constitution provided also thet the number of Senators and Representstives be flxed by the deneral Assembly and apportioned among the several counties, according to the number of white male ingabitants over twenty-one years of 80 . The number of Hopresentatives wes never to be more than thirty-s1x nor lese than twentyfive until the number of wite malo inhabitants should exceed 22,000, and after that event, the whole number of Repreaentet1ves wes not to exceed one hundred or be less than thirty-s1x. The number of Senators wes never to bo less then one-third or more then one-half the number of Representatives. ${ }^{2}$

1 Constitution of Indiane, 1816. Article III, Section 5. 
The Representatives were to be chosen annually by qualified electors in each county, respectively, on the first Monday in August. ${ }^{1}$ It wes necossary that a Representative be cltizen of the Unlted States, an inhabltant of the State of Indiana, and resident of the county, from which he was elected,for over one yoar. 2

Senators were to be chosen for throe years, on the flrst Monday in August, by qualified electors for Representatives. They were to be divided by lit into threo classes, in order to determine which group should serve one, two, or threo year terme. 3 It was necessary that a Senator b twenty-five years of age or over, olt1zen of the United States, to hove beon an inhabltant of Indiana for over two years, and to heve been an inhabitant of the county, or district represented, for period of twelve monthe or over.

Although this Constitution has boen superseded, the basic 1deas back of apportlonment in Indiana today

1 Ibid., Article III, Section 5.

2 Ibid., Article III, Section 3.

3 Ibla., Article III, Section 4.

4 Ib1d., Artiole III, Section 6. 
were incorporated in $1 . .^{1}$

Some of the characteristics of legislative districting in Indiana heve romined oonstant throughout Its history and cen be found in the present constitution. One of these is the provision thet the House of Representatives shell not exceed one hundred and the Sonate shell not exceed fifty mombers. That provision wes oarriod over into the new Constitution and is still in operation. 2

Another base 1dea thet is incorporated in the present Constitution is the proviston for counting the number of white male inhabitanta over twenty-one yegro of age every five years, and providing that the leg1slature hould reapportion on the bals of thet enumeration. Although the word "white" has been etricken out, and the perlod of years has been changed from flve to $31 x$, the idea of conducting speciel onumeration for the basis of apportioning the logislature 1 atill pert of the legal mochinery used in apportioning this state. 3

1 Paul Swank, Mathew Hamliton and Herman Yakey, "Indiana Constitution 1851," Living Wi th Your Government in Indiane (Ft, Wayne, Indiana: Ft. Woyno Printing Co., 1939). p. 269.

2

Ibid., Article III, Section 3.

3 Ibid., Articio III, Section 5. 
This first constitution, adopted in 1816, continued in operetion until 1851, when it was discerded and the present Constitution wes put into operation. The perlod of leglsiative history between 1816 and 1851 seems to hove been one of scrupulous sdherence to the constitutional provision. In conformity with Articlo III, Soction 2, an enumeretion of all the white male inhabitants over twenty-ono jears of oge was taken, and on the besis of this enumeretion the firet apportionment $18 \mathrm{w}$ wes pased on Januery $2,1822.1$

Under the provisions of this Act, (for text of Act see Appendix B, p.98.) the number of representative districts was sot at thirty-throe, with the number of Representatives toteling forty-three, while the number of sentorial districts was sot at sixtoen, with each district having one Senator. Dearborn, Franklin, and Washington were the only countles populous enough to be entitiod to one Senator each. Part of Warrick county was pleced in one district, and the remainder in anothor, an act thet would be urconstitutional under the present Conetitution. The ratio of Senetors to Representatives,

1 Indi ane Acts, 1821, p. 237. 
which was to be not less than one-third or more than one-half, was observed, and the first enumeration, the number of wh1te male Inhabitants exceeded 22,000, so that the Representatives had to bo more than thirty-six and leas than one hundred. Dearborn County wes the moat opulous, since it lone hed throe Representatives. (Soe F1gures 2 and 3.)

In 1825 the enumeration was again taken, and on the basis of this enumerstion, a new bill redistrioting the state was approved on Januery $19,1826 .^{1}$ By this time the number of countios hed increese to fiftythree, and the territories lying north of certaln counties were included es part of the representetive distriets. In this bill there occurred for the first time the prectice of combining two counties for one Representative, and then asigning one Representative to be elocted alternately in och county. This time there was total of fifty-six Reprosentatives to bo elected and twenty-one Senators to be elected. In 1825 the capital wes changed from Corydon to Indlanepolls, and Merion County wes allowed one Representative, but was forced to share ita Senetor

1 Indiana Acts, 1826, p. 301 . 


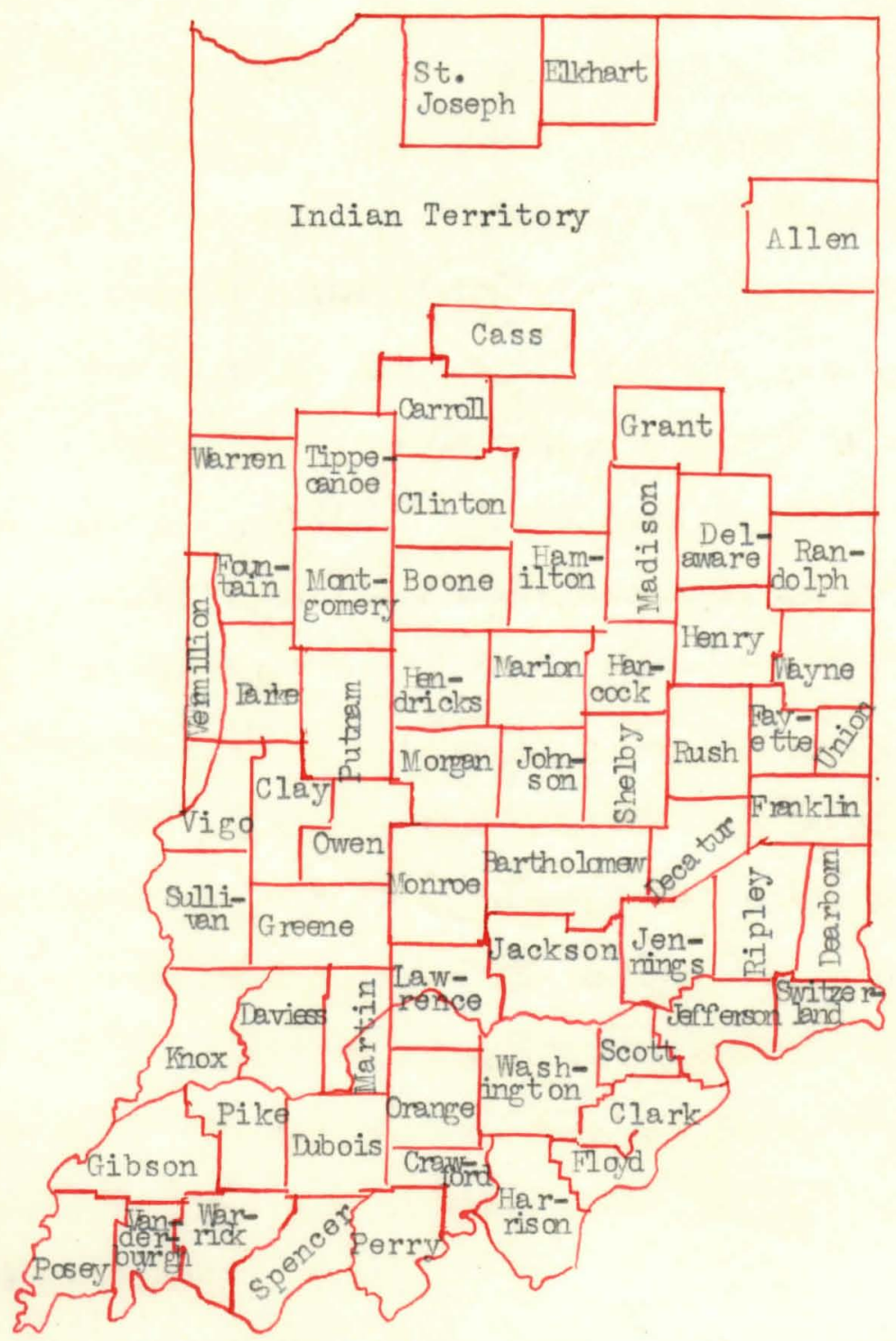

Indiana Counties in 1833. 
with Hendrioks, Hamliton, and Madison, plus all of the country north of the three last named oounties to the wabesh river. In the case of Fountain and Montgomery Counties, all of the territory north to the Indiane boundery was included.

On January 30,1331 , the tate wes redistricted for the next five year poriod. ${ }^{2}$ If these porlods appear rather short to the roader, he wust bo rominded thet the ste was growing very fast, populetion were shifting, new countl es were belng added, and the General Assombly wes moeting annuelig. There were then sixty-three counties to be considered in the distribution of cente. (See Map of count1es in 1835.) The number of senatore was set at thirty and the number of Representetives, et seventyfive. By this time wayne County had rorged into the loed and had four Representatives, whlle Dearborn County was second wth three. Marion County hed grown until 1t was now ontitlod to a full Ropresentetive by ltself, but was at111 forced to share its senator with Hamilton County and all the country north to the great Miaml reservation.

Heretofore, the title to all three of the Acts bad beon 1dentionl. Eech was beadod "An Act to Apportion

1 Indiana Acta, 1832, p. 56. 
the Senotore and Reprosentetives to the General Assembly." For the flrst time, on Januery 13, 1836, the title of the Act wes changed to raad - Mhat for the purpose of - leoting Senatore and Representatives to the General Asambly for the oneuing five jeers the atate shall be, end is, divided into the following distriots." 1 phis reises the interesting question os to what would here happened if now Inw hed not boen passed tho ond of the flve yeer perlod, but inow lav was pased, tho question beocmes la rgely academio. This wes the slmplest Senatorial apportionment law yot, ince it diridod the state into forty-sevon districts, and awarded a senator to each distriot with the exeeption of weyno, which was given two Sonatore. Whon the apportionment of Representatives wes erranged, howover, it wes an entirely different metter. If the mombers of the legialature were trying to confuse the voters, they suoceeded. In this one law they omployed lmoet oll possible districting plans. The number in the House for the first time was ralsed to the maximum $11 \mathrm{mlt}$ of one hundred members. of these one hundred, seventy-six were assigned in the ordinary menner. Of these seventy-six, membera, two countlee were allotted four och, one wes ivon three,

1 Indiene Aets, 1836, p. 561 
sixteen were allowed two each, thirty-three were elven one Representetive. The remalning countios were dividec into districts of three and four counties. Then one year eoch oounty would eloct one nepresentative, the next Jear one would elect two, and the remaining oountion one jolntly. Th1s procedure was rotated gens by yoer unt1l each County had eleoted one Repronentative jointig for three joars, and two by iteelf for two jears. In one cese, two countien were placed in one distriot, and the 1aw provided each was to eleot two Ropresentativos unt1l 1840, when one to eleot three, and the other one. Putnem and Lontgomery Count1es were to elect two each, and then an additional one wes to be elected elternately. The mont compliested plan, however, was the combining of five counties into one distriot, and neming three counties thet hould oleot one Representative each, and the other two one Representative jolntly. The countiea were then rotated so thet each jear a different three would elect one Ropresentetive ench, end different two would elect one Representetive jolntis. This plan worked out athematioully, so thet owch oounty roteted through the ontire ofreult in the flve yoar poriod, but the euthor cannot help but wonder how the syotom wes ever explained to the conetituents. Whon the act was finished, there wust heve been one Ropresentative remeining, for 
Jefrerson County us ellowed one Roprenentw tive in eddition in 1056,2850, and 1840. Eahtagton County wes -llowa one in addition to its regular allotment in 2839, and Clark County one 1 a 1837. (For toxt of Aot we Appondix B, p. 104.)

The next b111, whl ob wae approved January 16. 1841, appenre to fol20w very 0100ely the some IInes as

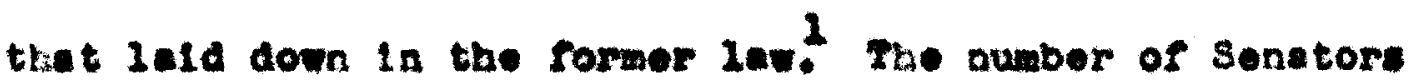
wat raised to the meximum 1 indt of fifty with each Qistrlot hoving one senter with the exeeption of Darne county whioh was allotted two. There were then elghty- lent countioe. In rediatrioting for the Representatives, the sesse compli onted postern was rollowed thet bad beon ueed in the 1836 plan. Agein the aumber of Fepre-

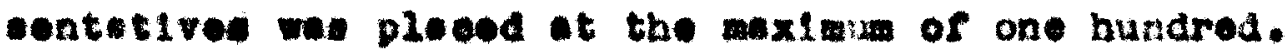
The 10 of 1846 mainteined tho retio of flfty to one hundred end also deflea any generel alaselftention." There was very $11 t$ te ohere in the sonatorial plan, but the egetem by whiot the Representetives were dietributed 1. difrioult to deseribe. The Lagleleture outlined ench dietriot ond Incioeted the nuber of Representatives

\footnotetext{
1 Indiene lote. 1842, p. 62.

2 Iadiene sote. 1846, p. 408.
} 


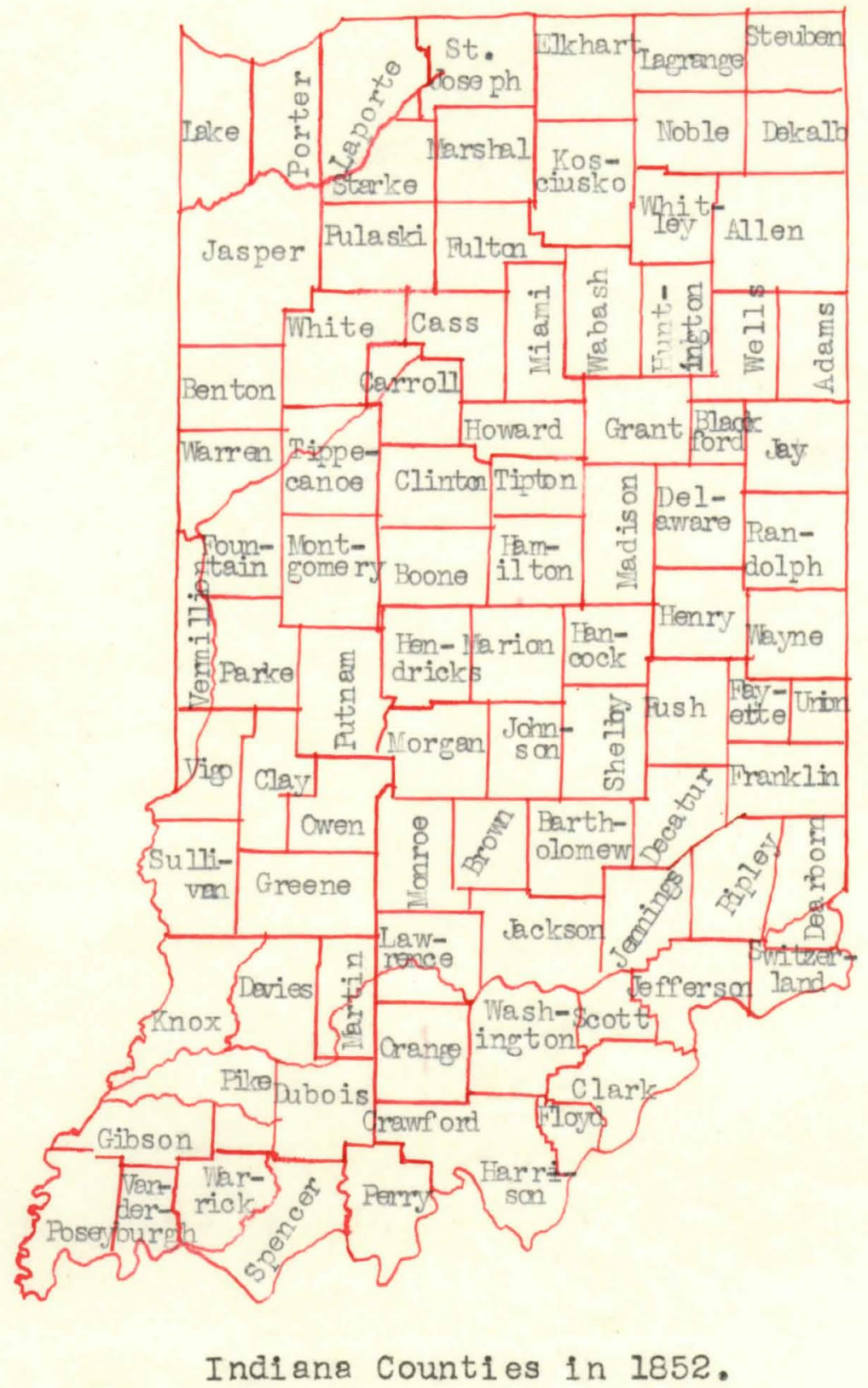


distri ot hould have exoh jear. The mubor varied in many districts.

The law passed on Fobruary 28, 1851, 10 ent1tiod to oloser soruting, because the 1s the lot that remalnod in effoot after the adoption of the now Conatitution on Norember 1, 1881. 1 By this time, there were ninety-one counties, and 1t only remalned for Monton County to be carred out of Jasper County and tho map would asume its present out11nes. (soe uap of Count1es 1852, p. 10) The number was retalned at Iffy and one hundred. Agaln the Sonatore were apportioned in relatively alaple manner, whl lo the same complicated mooheniom was dorlaod for the Ropresentatires.

The new Conatitution that went into effoct in 1851 changed the leglelative departaont in sevoral ways. ${ }^{2}$ The ohanged sectlons are as followas

Art1clo IV. Soetion 1. The leglalative authority shall be vosted in a Feneral Assombly, whl oh ahall conslat of senate and a House of Representatires.

Art101. IV. Section 2. The senate hel I not exceod IIfty, nor the House of Representatives one hundred meabers and they ahell be ohosen by the electors of the respective countios or diatriote, Into wich the state may, from time to time, bo divided.

Article IV. Soction 4. The Gonoral Ausembly shall at 1 ts socond session arter the adoption of this constitution, and overy sixth jear thorearter, cause an enumoration to be made of all the white male inhabitante over the go of twenty one joars.

Indiene 10ts, 2851, p. 97.

2 conotitution of Indiene, 1851, Art1010 IV. 
Arti 010 IV. Section 5. Tho number of Senators and Ropresentatives shall, the sessi on noxt following oaoh pertod of makling suob onvmeration, be flxod by 12w, and apportioned among the eoreral count1es, ocoording to the number of white mule I nhabltanta above twenty one joars of ago, In osohs Provided, that the fli rat and socond elections of members of the aenoral Aswembly, under this Constitution, shll be acoording to the apportionment last made by the aeneral $A_{8} s e m b l y$, before the adoption of this Conet1 tution.

Article IV. Seetion 6. A senatorial or Reprenentative distri ot, where more than one county hall on notitute a district, shnil be ocmposed of contigloun countios, and no one county for sonatorlal apportloment, shell over be di vided.1

The sessions of 1853 and 1855 wore, eccording to the ner Constitution, to be the sane se the last apportionment under the old Conatitution. ${ }^{2}$ The seseion of 1855. however, found no enumeration upon whloh to make an apportioment as then required, and, in the eleotion of 2856 , tho Assembly was chosen upon the prior apportionment. The Asseably, so obosen, at 1ts session in 1857 , whout an enumeration, epportioned the state, and w thout further apportioment the Ascemblies following that session were eleoted under that apportioment unt1l Governor Morton in Junuary 2865 called the attention of the seasion, thon altting, to this long oontinued fallure of duty. 3

1 Conatitution of Indiana, 1853, Artiolo IV. Soction 2, 4, 5, and 8 2 Ibld, Artiolo IV, Sootion 9. 3 Indiene 10te, 1857, p. 309. 
The reason there had been no enumeration taken since the adoption of the new Constitution was that, while the Constitution stated that an enumeration should be taken every six years, there was no administrative machinery to execute this provision of the Constitution. When this fact was pointed out by Governor Morton/his message to the General Assembly in January 1865, they respondod by passing the sorealled Enumaration Law. The title of this law read, "in lat to provide for the periodical enumeration of the white male inhabitants of this state over the age of twenty one years."

The administrative machinery was set up in complete deta11, making it the duty of the township trustees to make a complete enumeration of all wite male inhabitants over twenty one jears of age in their townships. ${ }^{2}$ This enumeration was to be made in the year 1866, again in the jear 1871, and at the end of each successive six year period after the last mentioned year. ${ }^{3}$ The township trustees were to perform this duty between the first day of January and the flrst day of July of the designated years. 4

\footnotetext{
Indiana lets, 1865, p. 41.

2 Loc. c1t.

3 Loc. c1t.

4 Ibla, p. 42.
} 
After ocoupling a list of 211 white malo inhabltants over twenty one yoars of a in tholr respeotive townohlpe, the trustees wore required by law to arrange tho names in elphabetien order, and to submit thom to the county aditor. The oounty auditor was roquired to arrange all of the townuhips of tho county in alphabotical order, and after so arranging, to publidh them in the two loading nowapapers of that county. After walting porlod of ton days for corrootion, the county auditor was to send the corrected list to the auditor or the tato. The auditor of the state, upon rocelving these reports, was to make and to cortify tabular statenent of the number of white male inhabitants of the state of Indiane over twonty one years of age by townahipe, and counties. Tho atate auditor was to hare printed three hundred outlino mape of the state of Indiane, howng the number of whtte male Inhabitants orer twenty one jears of age in enob township and county. These mape were to be dellvered to the speaker of the Elouse and the President of the senate, two hundred to the former and one hundred to the lattor.

This onumeration 1 w remalned inteot from the time of 1ts passage on December 21, 1865, unt12 the session of 2877, when an additional act was passed, providing that the same agencles, that made the ommoration of all white mule inbabitants orer twenty one yeare of age, should also 
make an emweration of all colored male inhabltants over twenty one years of $8.0^{1}$ This $1 \mathrm{ar}$, in $1 \mathrm{ch}$ is at111 in force, provides that the col ored 11ste ohall be kopt soparete from the white 118ts. As noted elsewhere in thie work, the Constitution wee monded in 1881 to strike out the word "vilte". 2

These two acts romalnod in force and unchanged unt1I Yarch 9, 1937, when an act was approved, changing the dutios of the emumerator from the trustes to the townahtp assessor. 3 The seoond paragraph of this Act of 2937 states that the enumoration shall be taken in 1937, again in 2043, end overy six jears thereaftor. Thls latter act only affocte the more populous oounties, as the townchlp trustee and townohip aseessor are the seme In tho smallor tomachips.

On the basis of the flrot emumeration taken under the orlgl nal act of 1865 betwoen January lat and July 10t of 1866, the General Assombly paseed the apportionment Iaw of Fobruary 26, 1867.4 There were thon ninety two counties and under this act only uarion county: recelved two senatore. It was necessery to

Indiana Lots, 1877, D. 50.

2 When Indiane Constitution is anonded the eotual wording 18 changed.

3

Indiene Lots. 1037, p. 500 .

4 Indiane Aote, 1867, p. 181 
Inolude four counties in one large distriet and to glve then one senator. Whon it came to Ropresentetives, It appears to have been a rather easy mattor a 1s0, for the mejority of the counties reoelved one heprosentet1 ve oach. Vanderburgh, Iarion, wayne, Tlppoonoe, and Allon counties recel ved more than one. The largest ropresentative distri ot bad throe countios.

In 1872 the second saumeration was conducted, and on December 87, 1872, new apport1 onmont 1aw went Into effect through lapes of time, because the Governor refuned to $\mathbf{s g n}$ the bill. Whon the law of 1872 is exanined and compared with tho Ian of 1867 no etriking differenoes appeax . Thore was some ahifting of counties Into different representative districts but no one county gal nod or $208 t$ much in the rediatrl eting. (see Appendix, p.120)

Tho next twonty II je joere might well be called the constitutional period in the hiatory of epportionment. in Indians. During this period apportioment lawe wore passed in the joars 1879, 1885, 1891, 1893, 1885, 1897, 1905, and 1905. Of the o1ght lawe f1ve wore at one time or another declered unoonstitutional by the suprome Court of Indiana. It was during thls porlod that

2 Indiane Acts, 1872 , p. 609. 
the supreme Court and the General Assembly battled to see which should have the final authority over epportionment in Indiana. Out of these issues, however, came a set of mules, limiting in a vague sort of way, the field of apportionment in which the General ussembly might operate.

In the law of 1879 there occurred, for the first time, the use of the somalled "double district" ${ }^{1}$ The court, in the case of Denney Clark, et. al. v. state, defined a double district as the grouping of two or more counties, neither or none of whichbas a voting population equal to the ratio for a Senator or a Representative, and giving to the district so formed more than one Senator or Representative:

The interesting fact about the law of 1879 is that its validity was not challenged while it was in effect. The law was in force from March 8, 1879, to March 6, 1885, when it was superceded by the law of 1885.3 The law of 1885 served $\mathrm{s}$ ix jears without being questioned legally, and on March 5, 1891, a new law was passed over the Governor's veto. 4 This 1 aw was immediately challenged In the case of Parker v. Stato, and in 1892 the Supreme

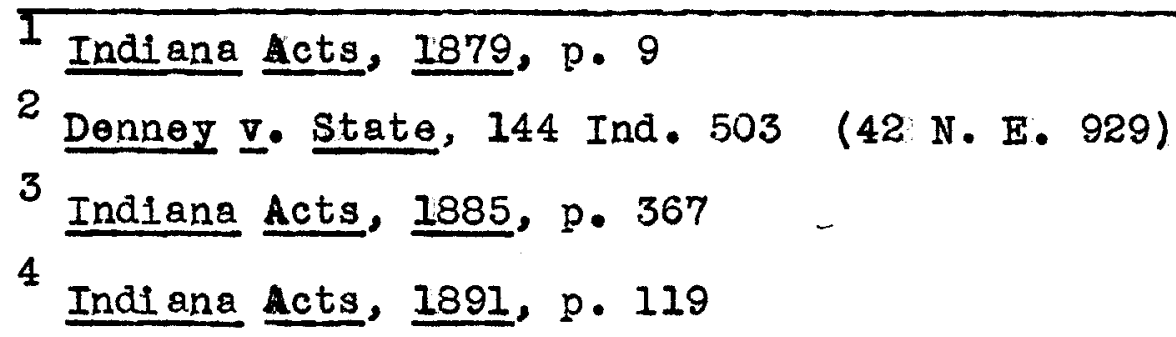


court mied that both the 1 awe of 1891 and of 2879 wero unconstitutional. Tho plalntiff had sought to bare both the 1891 law and the 1885 lav set asde so that the 1879 Iaw would have been in effeot.

After the supreme court had ruled invalid the Iawe of 1891 and 1879 , the Gonoral Aeacobly mot in 2898 and passed now Inw which went into effect on Varoh 4. 1893. I This 1 aw of 2893 was immodiately ohnllenged in the courts, and the ceneral Assembly, ovidentiy fooling that it would be deolared unoonstitutional by the suprome Court, met in 2896 and pased an lot repeniling the sot of 1893. The repealing aet wa passed over the Goremor's veto. The General waembly then paseed a apportionmont In over the Gorearnor's roto whioh went into offeot var on $5,1895.8$

Both laws of 1895 were then chellenged, and in 1806. In the oase of Donney $\nabla$. state, the suprone Court uphold the $M$ ght of the coneral Assembly to ropeal a former apportionment et during 1ta a1x yer perlod and pasa a new one if the old one was uneonatitutional.

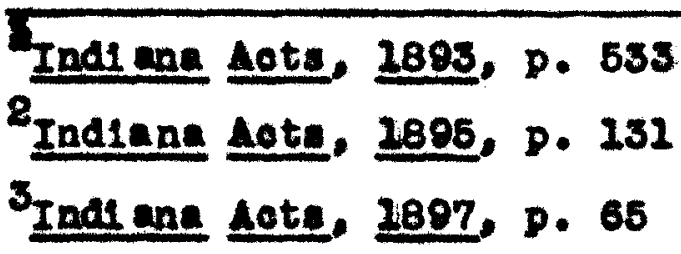


The court held that the Iaw of 1803 was unocnatitutional, consequently tho Goneral Assembly had a right to ropeal 1t, but that the 1aw of 1895, whioh they passed in 1ta place and that wont 1nto offoct on Maroh 5, 1895, was also unoonst1tut10nal. The ocurt then polnted out that - Inee the lawa of $1879,1891,2895$ and 1895 had all boon ruled Inval1d, It was neoessary to revert to the law of 1885 unt1 1 const1tut lonel apportlommont las could bo passed.

The next sess10n, whl oh mot in 2897, passed two b111. On Maroh 5th, now apportionment 1av, whioh the covernor slgned, was passed, and on Maroh 6th, an aot ropealing the not of 1885 was approred.

The epportionment Iaw of 1897 romel ned in force the full perlod of $1 x$ joars and on March 8,1803 , now Iaw wont Into effeot. I Tho law of 1903 was ohallonged and in the case of Brooks V. State, ${ }^{2}$ and in 1004 the Suprome Court handed down a deolelon in whioh 1 t stated that the apportioning was done in an "unnecossarlig unequel" manner and the Aot of 1903 was invalid.

1 Indiane 10te. $1003, \mathrm{p} .358$.

2 Brooke I. State, 168 Ind. 568 (70 M. B. 980) 
This condition was remedi ed at the next session, and the now law went into effeet on Maroh $8,1905 .^{1}$ The enwasation for now aot was taken in 2807 , but the Conoral lasembly falled to reapportion durf ng that alx yoar perlod, so the lan of 1005 remained in fores unt11 new not was approved on Maroh 9,1915 , based on the emumeration of 1913.8 The lot of 1915 was follored by the present law, passed in 1921, based on the enumeration of 1919. Since 1921 the enumeration has been taken in 1086, 1931, and 1937, but no erfort has beon made to roapportion the state.

\section{1 Indiene sote. 1005. p. 117. 8 Indiane 1eta. 1025, p. 656.}


GEUPRER II

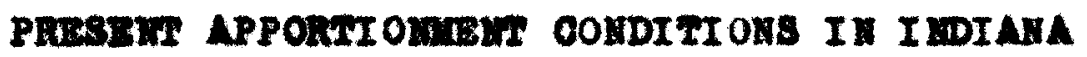




\section{PRESENT APRORTTONEWT CONDTTTONS IN INDIANA}

The state of Indiane is now operating under an apportionment 18 passed in 1921, besed on an enumeration taken in 1918. Under existing laws there should heve been three epportionment acts passed since that time, but so far, the leglsiature has not seen fit to do so. 1 This is the longest period in the history of the state of Indiane thet hes pessed without an apportionlag law of some description belng onacted. There appears to be no reason for the state of Indiana to bear the expense of taking an onumeration every six yoars if the logialeture is unwiling to use the figures complied. While the constitution clearly provides thet:

The number of Senators and Representatives she11, at the next session of the leglalature following the enumeration be fixed by law and epportioned amone the several countios, according to the number of mele inhabitents over twenty one years, 2

there appears to be no way of forcing the leglalature to ect. In the case of Fergus $v$. Wckinney the supreme court of I1linols held thet "while the duty to district the state is mendatory power, the court cannot compel the legislature to do so.n ${ }^{3}$

1 Lawa should have been pasad in $1927,1933,1839$.

2 Indiana Constitution 1851. Article 5, Section 6.

3 Fergus I. Mckinney, 164 . 665. 
Tho Suprese Court of Indiane bas conaletent2y

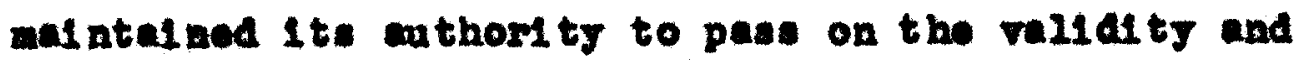
soope of subh acts whon tboj hare been paseod, and draw 1t. authorfty from oeses in othor atates. I so the conolusion wight be reachod that the oomts all make no attempt to foree the leglalature to at, but once the aot hes been passed, thoy whor no hosltaney in deelarting It Inralla if it does not follow the dietates lald down by the Constitution.

In Indian the ocurt hes lald down cortaln gonoral ralos to whioh the loglelature mut oonform in distroting atate. In Parker $r$. state the oourt sald that the Conatitut10n, "roqui red the 20 glelature, in apportioning the state into legielative distriots, to epproximate equality in ropresentation betwen dietriots, or as noarly as poselble, and the loglelature has no power to do otborwlso." ${ }^{8}$ The coust wht on to say that Wan Lot of uareh 8, 1879, and an Lot of Marah 5, 1891, in offect donjing a county having more voters than the ropresentative unit, a representetive, and giving certaln countios osoh heving lose roters than the unt sentative onch, and aselgning thom to distriote with

1 gtete. ex, rel. I Gunnlaghen, 81 W1:. 440 (15 L.R.A. 562.)

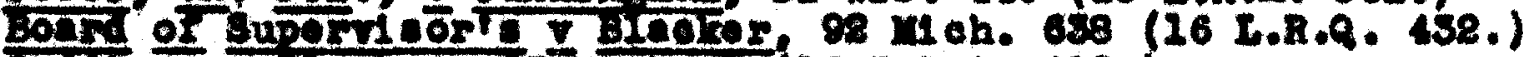

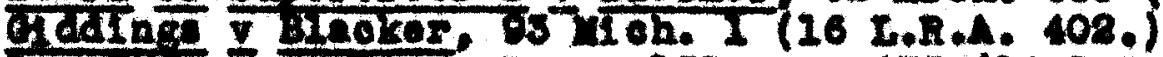

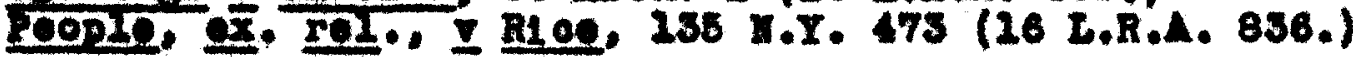

2 Parker I state, 733 Ind. 178 (32 M.B. 836.) 
other countios not contiglous, were uncontitutionel."1

In the case of Brooks V. State the oourt sale that "the apportioning of senutore end Representetives in an unnocessarl $2 \mathrm{y}$ unoqual monnor was unoonstitutional, "ne When these acte are examl nod, to uee a a jardetick it 1 s found that in 2801 th Ioglelature had rormed 45 countios into 22 detmote, to ench of whl ob ono somator was allottod, eleven of whl ob distriote, composed of twenty three oounties, contelnod 248,406 20gal roters, whlo tho other eloven distrlete, composed of twonty counties, had only 99,608 such votere. 5 This distribution wea held to be unnocesuanily unoquant

Again in 1008, in the ose of Brooke v. State, the court found forty-81x counti es forwed Into twonty diatriote Ith one sonator each. Ton of those diatricts, composed of twonty-e1ght countied, contalned 160,767 ane Inhabltante, the othor ton distmots, composed of el ghtoen count1 oa, containod 127,360 mal I ihabltanta. Thl was also beld to be "unnecesearliy unoqual:

\footnotetext{
Ioe. a1t.

2 Broola I. State, 168 Ind. 668 (70 I. I. 980.)

3 Indien Aote. 1003, p. 358. 4 pennr I. state, 144 Ind. 503 (48 M. B. 989.) 5 Broo) I. State. 268 Ind. 568 (70 I. B. 880. )
} 
If the rule of stare docisis is nocopted, somewhere between these outside limlts and the theoretioaly perfoct apportlonment law is the practical solution which can be reached. In tho cese of Donny $v$. state, the court seld:

Double distrlets, that is the grouping of two or more countios, nol ther or nono of whloh has voting population equal to the ratio for a senator or a Representative, and giving to the di stri ot so formed mor then one senator or Ropresentet1ve, are not permisable.

In the ane osse the court 180 beld thet

The loglslature may ropeal an uncontitutional apport loment lav ung time during ame omumeration and pass anotbor, even before tho firat has fudi ol $21 \mathrm{y}$ boon declared unoonst tutional, but cannot ropeel a valld epportl onght law or reapportion tat during such act."

With thl s background the tatus of eportionment in Indinn at the present time, es provided by the loglslative act of 1921, besed on the enumeration of 1918, oan be examinod.

In $\mathrm{MG}_{\mathrm{g}}$. No. 4, the present senatomal apportionment mep is outilned. Thi map shows forty-four enatorlal distmete. In each of rorty-two of these one senator is - looted. Lake county district elocta three and uarion

1 Denny I. state, 244 Ind. 503 (42 \%. B. 828.)

2 Ioc. c1t. 
County distriat eloote I1re. Because of the constitutionel prohlbition no ocunty oan bo dividod into soparate sonatorlal detriote but it mey eloot more than one at 1arge. (8ee Lake and rart on Counties.) ( county may eleat one alono and leot another jointly of th an adjolning county. (seo M160 and sullivap counti es.) Only adjolalng countios on be put lato the same senatorl al distriet. ${ }^{2}$

An examination of the 11st of malo Inhabitants emanerated in 1910 and the quota for senatorial apportionment showe the statiaticel basis for our prosent apportionmont. A exitioel examination of the number of Senators allotted to each distriot, and a compamson to the thoorotical number to which it was ontitled by its quota, w12 bear out the assertion that 1 t was a very equitable dietribution, However, if the centus Il greses of 1980 and of 1940 are compared, strikeng shifts in population, of wht on no account he been taken, are not od. (seo Appondix, p.94 .) A ortical extend nath on of those

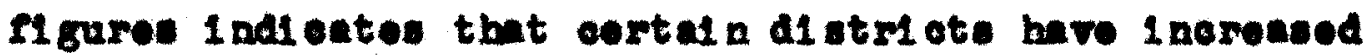
onornouly in populati on in the last twenty-one years whl 20 others bave 20st in population. The following countion galnod more than forty thousand in population alnee 1080.

Indiana Gonst1tution, 1851. Artiole 4, gootion 6. 


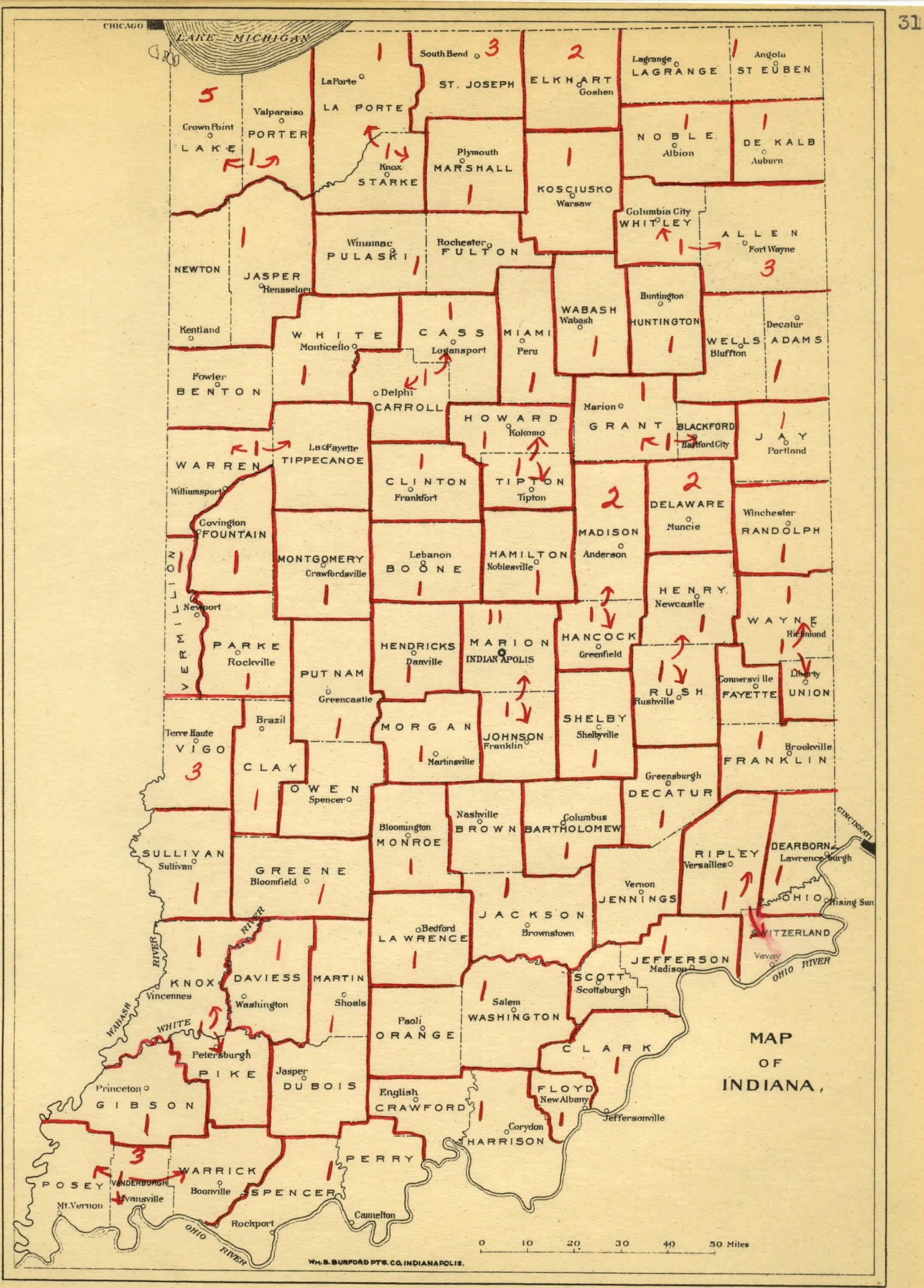

31 


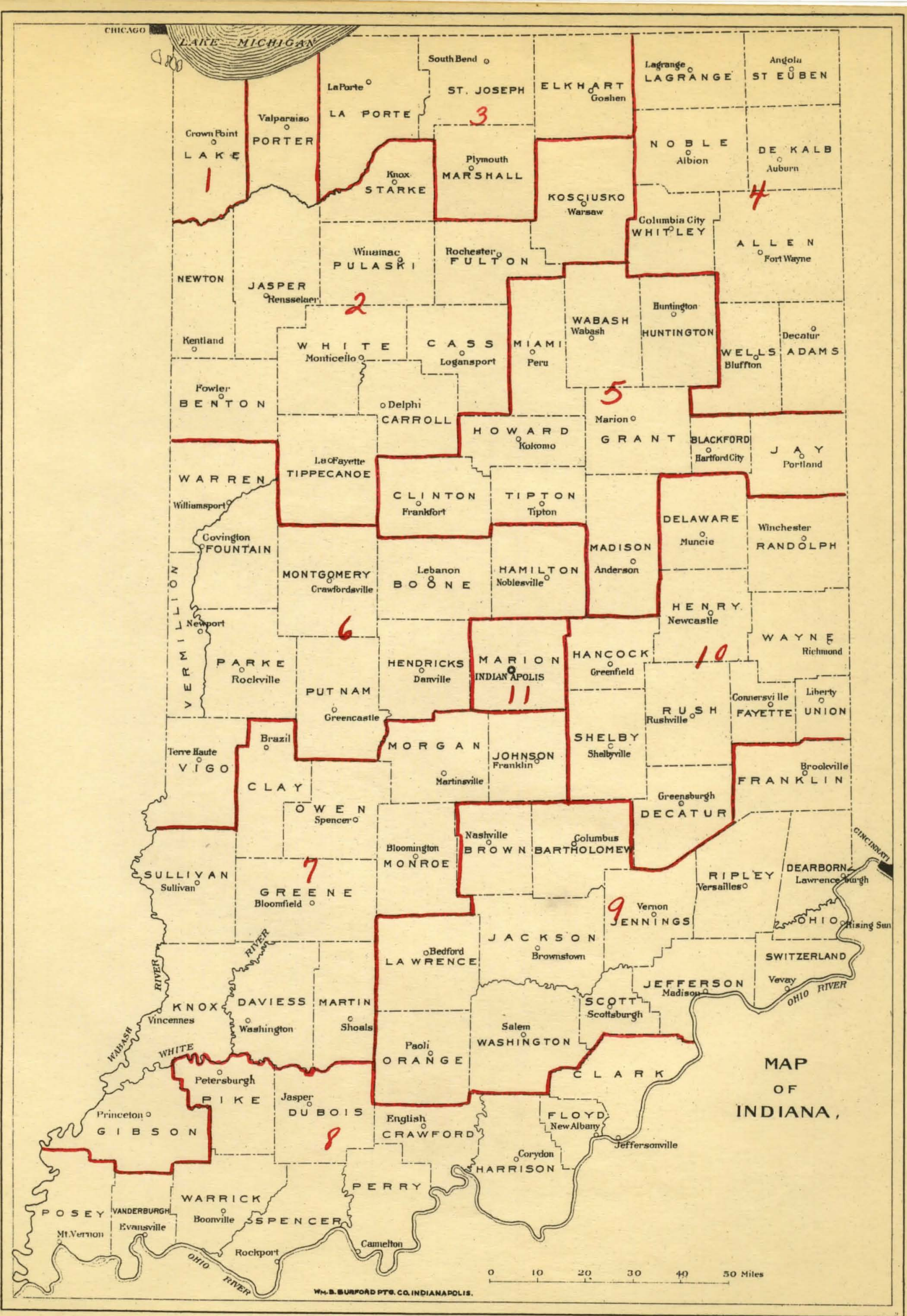


gountr

Alen

rake

Iarion

8t. Joseph
Qain in Population from 1980 to 1940

40.530

128,326

108,608

58,633

POTAF.

The following oounties gal ned between 20,000 and 40,000 in population sinoe 1880 .

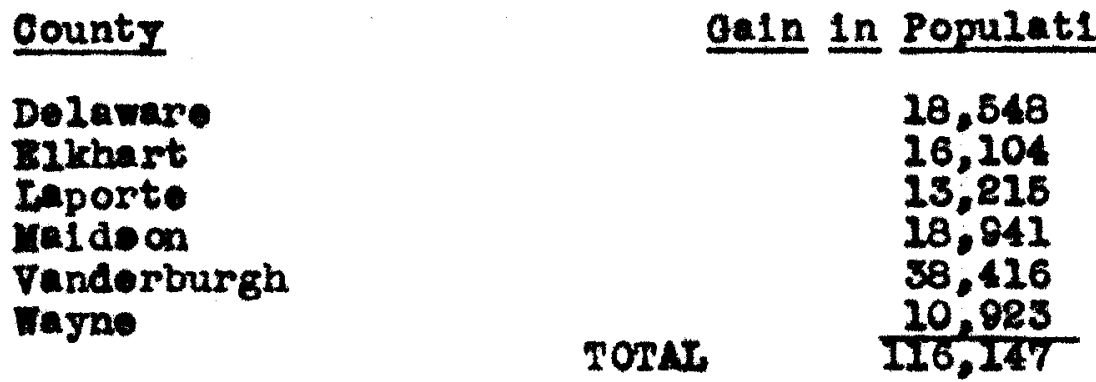

The following counti es gat med between 6,000 and 10,000 In population since 1980

Qountr

Deamborn

Nob10

Porter

Tippecanoe

Inivrenoe
Gain in Population

6.850

5,264

7.711

8,405

7,327

The total gain for the entire atate during this period was 485,762 . The fact that the total of gain in those countios that increased in population more than 5,000 is greater than the total gain of the ontin tate ia easily explained won the fact 1 noted thet some of the oounti es setull 25 decreased in 
population. Consequently some of these inoreases undoubtedis represont shirts in population.

Botwoen 1020 and 1040 the following oountios

deoreased in population:

\begin{tabular}{|c|c|c|c|}
\hline County & $\frac{\text { Decreane in Populati on }}{\text { Io } 20-\frac{1040}{1040}}$ & County & $\frac{\text { Deorease in Popr- }}{\text { Intion }}$ \\
\hline 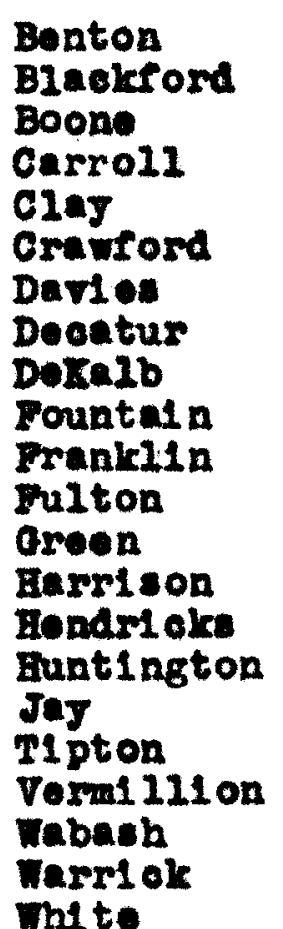 & $\begin{array}{r}949 \\
386 \\
1459 \\
1585 \\
4880 \\
1041 \\
756 \\
142 \\
891 \\
515 \\
408 \\
537 \\
5477 \\
1555 \\
139 \\
1829 \\
831 \\
1046 \\
5862 \\
665 \\
441 \\
837\end{array}$ & 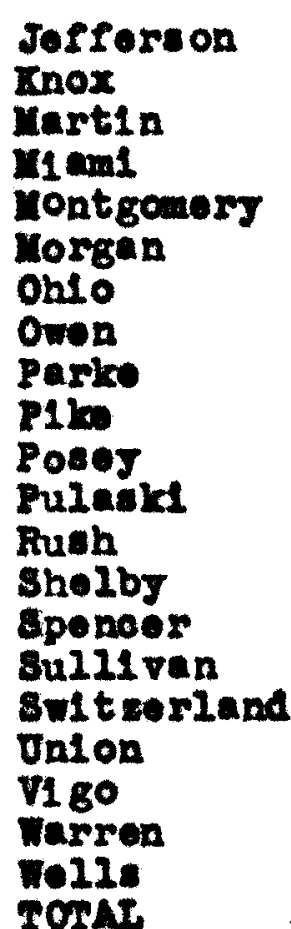 & $\begin{array}{r}804 \\
2380 \\
1587 \\
858 \\
1223 \\
812 \\
860 \\
602 \\
1622 \\
1658 \\
170 \\
326 \\
226 \\
58 \\
2191 \\
4847 \\
1147 \\
8 \\
745 \\
666 \\
1405 \\
51818\end{array}$ \\
\hline
\end{tabular}

81 nee there has been no ohange in the allotment of Senators during this perlod, these flgures alone are onough to show that there are a great many disoropanoles in epporti oment. Further oxcul neti on dicloses tho following facts. In the twenty joar porlod betweon 1920 and 1940 the state of Indiena Increased from $2,930,380$ to 3,416,162, galn of 13.1\%. During this sume period the e1ty of Indianapolis went from population of 314,194 in 
1820 to 386,170 in 1940 or an increase of $22.8 \%$.

Increases in Population of Prinolpal C1ties

O1ty

Fort Vayno

Gary

South Bond $\frac{\text { Population }}{\text { I020 }}$

86,549

55,378

70,883 $\frac{\text { Population }}{1040}$

128,193

110,863

101,410 $\frac{\text { Percent }}{\text { Increese }}$

36.8

100.1

48.8

In 1920 , there was one senator for every

56,606 people; in 1940, there wae one Sonator for every 68,383. The total population of Mam on County mubers 456,669 people, represented by 5 senatore and by one senator in conjunotion with Johncon Counts. Upon subtraction of Johnson county's 22,448 populati on from the theoretioal representation of 68,383, it is found that Iari on County uppl1es 45,875 poople for their jolnt Senator. When the 48,875 people for the jolnt senator are subtracted from the total population of Harl on County, there romalne 410,794 people for five Sonatora, each senator ropresenting 82,268 poople. At the same time in the Whitley and Huntington distriot one senatior represents only 46,776 people. In Lake County each Senator represents 96,094 people. In st. Joseph and Marshall oount1es there are two senatore for 191,017 poople, and after tho joint sonator 1s subtracted, the other senator represents 123,594 pereons. 


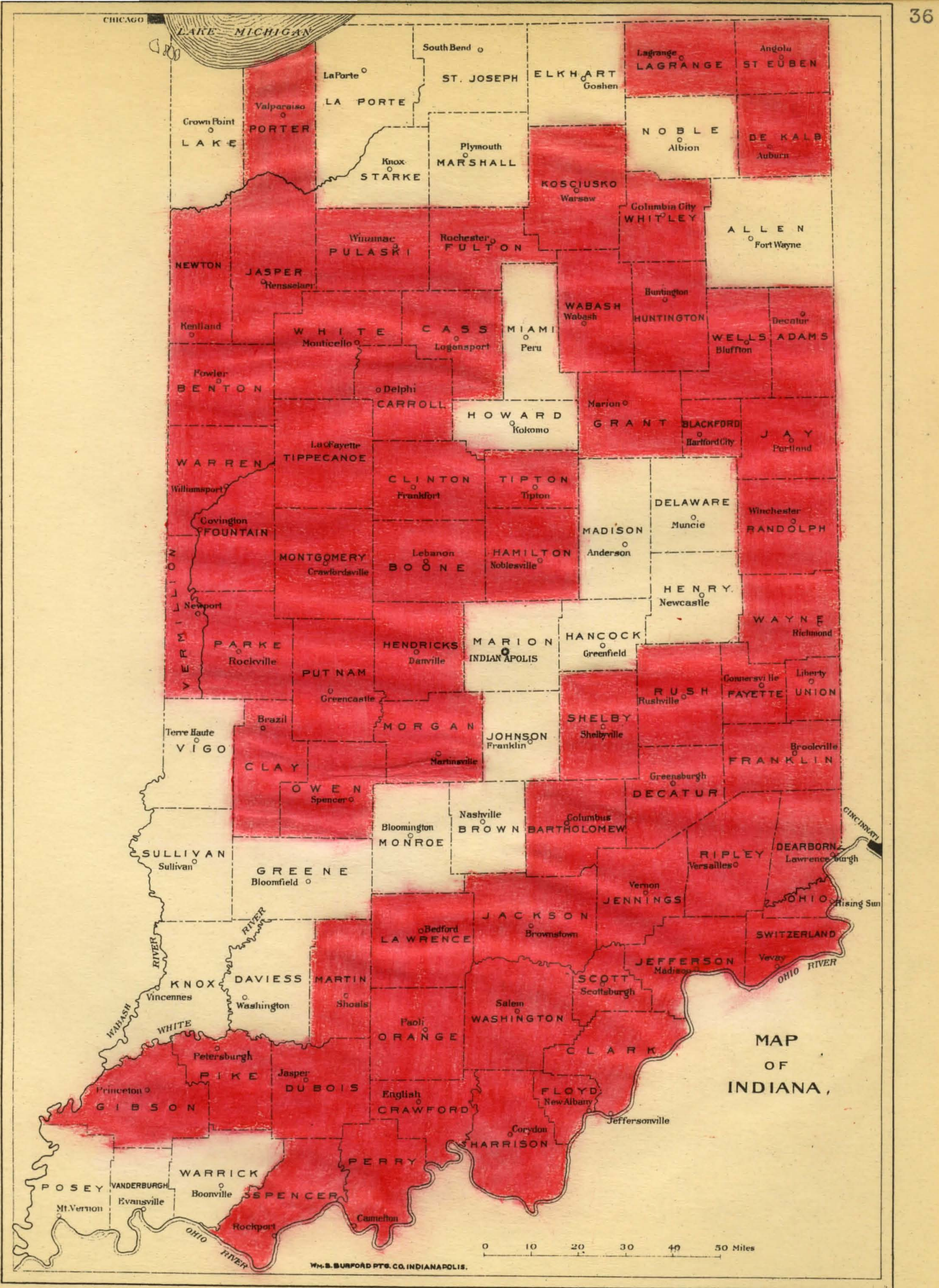


In Allon County one Senator represents 209,244 persons.

The following counties conten $37 x$ of the total population of the state, but they have only $28 \%$ of tho sonatorlel ropresontation.

\begin{tabular}{|c|c|}
\hline County & Populatior \\
\hline $\begin{array}{l}\text { Lake } \\
\text { st. Joseph } \\
\text { Vanderburgh } \\
\text { yart on } \\
\text { Vigo } \\
\text { Alion }\end{array}$ & $\begin{array}{r}288,283 \\
161,967 \\
130,709 \\
456,669 \\
89.467 \\
154.833 \\
\end{array}$ \\
\hline
\end{tabular}

The following counti es represent more then one half of the population. These same countien have only 20 out of 50 senatore.

county
nayno
Vigo
Vanderburgh
st. Josoph
Yarion
yedison
Iaporte
Iake
Howard
Grant
Blkhart
Delavare
Joyd
Ilion

Population

59,059
89,467
130,709
261,967
456,669
88,092
63,658
238,283
47,834
55,717
72,488
74,925
35,048
164,833
788,749

Upon examination of the figures for the House of Representatives, the following frots are found. On the besis of the 1940 Census each Representets ve represents 
34,261,58 peop20. However, an exeml nati on of the loglaInt1 we alstmete alsoloses the raet tbat in Boone county One Ropresentetive ropresente 22,010 people, in Dearborn und Ohio Counties together 20,387 people, in Dernib County 24,700, In Fondrides County 20,288 and in Jay county 82,487 people.

On the other extrems the Representative in the rake and Porter distm ot represente 6R,663 people, or more than $t$ to es wang people ar in Dorelb, Jay and Hendri oke oountios. In st. Joeeph County enoh Representative ropresents 63,069 people, in the $1210 \mathrm{n}$ and whtlor distriot 18,042 people, in the Posey, Vanderburgh, and Warrlok distet 19,393 people.

On the besls of these figures it might be sald that one man's vote In Boone, Dearborn, Ohto, Jay or Dexalb ocuntios counte twioe an woh for loglelative purposes as in reike, Porter, Al2en, or Vendorburgh ocunties. Those Ilgures polnt to the feot that the state noods rodietmoting. One naturel2y wondere if there w12 be basio uht in the control of Indt an whould it be redietmoted. The question now Hoes as to what interests A11 conklot, snd what besards provont rodistroting.

A pertunotory glanes at the anp w11 show that cortal $n$ seotlond of Indi wa are growl ng moh faster than

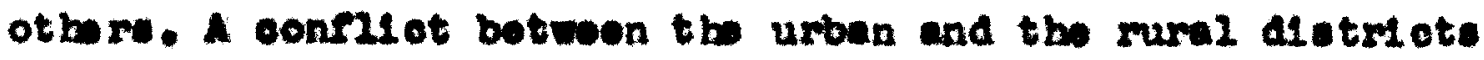


1. 21kely to ar1se. I map of the state of Indiana, with those countlos blooked off that have more than one mandred people per equare mile, di seloses those countios that are prodominantiy urban. An oxeal nati on of these populous counties ahow thoy have $1,788,744$ poople, or more than half of the population, but ther heve onls 28\% of the representation. In other words, the oontrol in the Indian leglelature at the present time realdes in the less populous distmots. A ohook of the counties in Indian revoals the feot that those with Inereased population are predominately urban, while those with decreased population are prodominately rural. Thi a trond is noticed whon tho consul fl gurse of 1920 . elessifying 50.65 of the population of Indiens arsan, are compared to the census rigures of 1050 , olnsalfying $55.0 \%$ of the poople of Indi ana as urban. Wo flgires for 2940 are jot avallable, but all other al gna Indieate the trond has contI mued. The Unt ted States Cenwus lists all ol tios ovar 2,500 as urban.

since the present apportionment law was passed, the total population of the state of Indiana has ond I nereesed 23.1\%, while the of ty of Gary has 1 noreased 100.16, South Band 42.8\%, Port Wajno 36.\%, and Indianapolls 22,8\%, Other urban oenters bave made lesser gains. 
Thus, it mlght be safely asserted that the oontrol would have tended to sinft from the rural to the urban count1es. This beoomes more obvious after observing that the following nine counties here 45, of the population of the state.

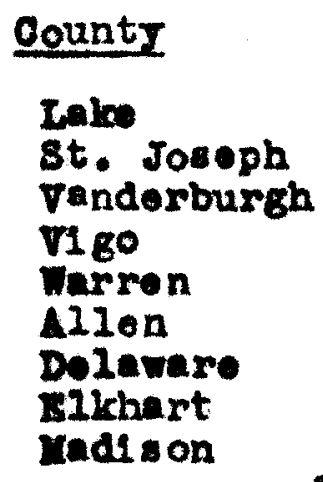

Population 288,283 161,967 130,708 89.467 486,669 254.833 74.925 72,488 88,008 TOTAL $1,527,131$

Anothor question involved, perhape the major one, in that more interest would be centered on it than any other, is whothor elther of the mafor pollticel parties would gain by a redistrioting of the stete. In order to arrive at any conclusion, the fects must first be assombled for use as basis. Tho Presidential election returns, by countios, for both 1836 and 1940 were used. The former represents a Demooratic majorlty, the second a Rublloun majorlty. In order to get away from too strong a pull, es the rosult of personalitios, the returne, by counties, for the office of Secretary of state in both 1934 and 1938 were used. The former ropresonts Demooratio victory, the 
latter a Republican.

Democrat1c Countios in 1934 and 1938

Ldams
Blaokford
Brown
Clark
Crewford
Doarborn
Clay
Dubols
Floyd
Frankin
Gibson
Qreone

Hanoock
Harrison
Jacks on
Johns on
Knox
Lake
Yadison
yart on
Ohlo
Porry
Posey
Putnam

Ripley

Soott

Shelby

sullivan

sut tzorland

Vandorburgh

Vermilizion

V1 80

weshington

Ne12.

Fopublican Counti on in 1934 and 2938
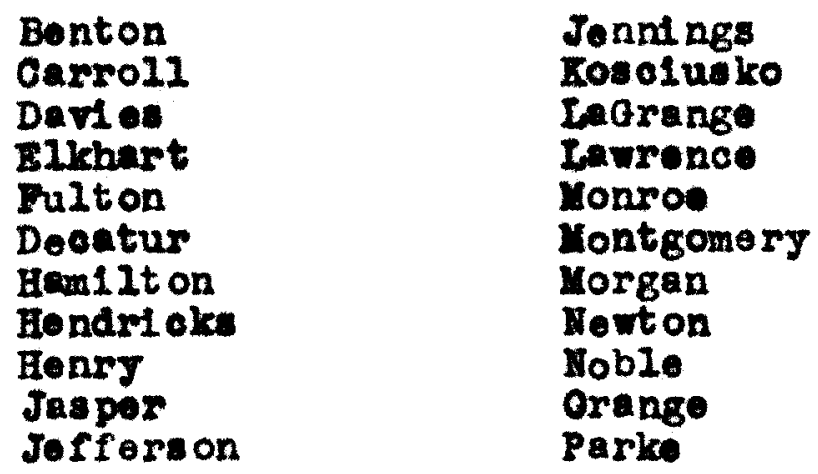

Porter

Randolph

Rush

Steriben

TI ppoenno

Union

Nabash

Wayne

White

The totel gein in population of all Democratio countios in 1934 and 2938 was 319,942 . The total lowa In the same countios was 25,064. The net gain in Democratic countlea was 294,888 .

The total gain in population of all Ropublioan countios in 1934 and 1938 wes 69,019 . The totel loss in the same count10 was 9,498 . The net $g$ (n) was 59,521 . 
Democrat10 Gount10 in 2934 and 1938 that galned more than 5,000 in populati on are 11 sted belon.

County

Dearborn

Lake

Yadison

Martion

Vandorburgh

Qain in Population

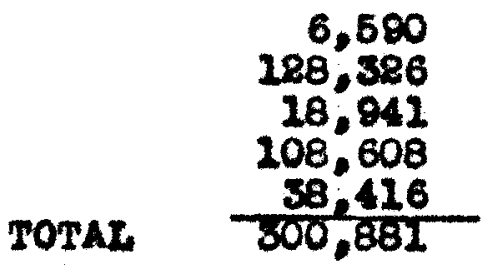

Republioan wountios in 1934 and 1938 that gained more than 5,000 in population are listed below.

Countr

Henry

Iavronoe

Yob10

Tippocano*

Wayne

Porter

Elkhert
Qain in Population

5.480
7.328
5,264
8.405
10,923
7,712
Torat $\quad \frac{16.204}{61.2115}$

These Il gurea indloate that no Republican county has gal ned more then 26,104 people, while two Domooratio countles have galned more the 108,608 peoplo. $4100,=11$ but one of those oounties that are under-represented are Domocratic. In auming up the finding based on the racts arrenged in this study, three conclusion may bo sated. Flrat, the representation in Iradin is not -quitably detributed if jou assume that population should be the besis for representetion, second, eny redietrleting on an equiteblo bas would tend to throw 
the control from the rural to the urban elements of tho state, third, hould tho great mass of tho people maintaln tholr present riews as to party alignment, a redietrioting wo uld tend to favor the Demooratio party. 


\section{CHAPTER III}

PRONOSED IETHODS OF FEDISTRIOTINO THE STATE OF IMDIAKA 
PROPOSED METAODS OF REDISTRICTING THE STATE OF INDTANA

The two plens of redistrieting the State of Indiane that follow in this chapter are moant to be only suggestions. Those plens are to serve only as broad outlines thet mifht be followed. The two plens differ in tholr treatment of the smell counties. Plan A keops the small countios voting as separate units. Plen $D$, on the otior extreme, merges the smeller counties with their larger nelghbors.

In eithor plan, certein preliminary stops aro necessary before an equituble plen can be doveloped. On the followin pages there is an attempt to outline these stops, and, at the same time, to furnish the necessery information to any reader who mifht be interested in redistrictine the state of Indian.

The flrst step that must be taken in any consideretion of rediatricting is the determination of the quota. by quote is meant the number of inhebltants each loglslator would represent if the state was perfectly apportioned. Fleures revealed that in Indian a Senetor should represent 68,555 people and a Representative should repregent 34,277 people.

The second step is the listing of those counties that have more populati n then the theoretical quote and the number in excess in each case. After disposing of 
61

the more populous counties, it is advisable to list all the counties and thelr derlation, abore or below the quota. From this polnt on 1t boocmes matter of ohifting the counties into different combinations unti 1 the ererage deviation has been reduced to the lowost point.

SEMTORIAL DISTRICTS -- Quota 68555.

Those counties having more than the theoretion quota:

countr

take

St. Jos oph

Elkhart

Alion

Deleware

Iadion

yamion

V1 80

Vanderburgh number of senatora Mumber above puote

18,075

24.713

4.079

17.994

8,408

20,020

49,596

31,154

62,228 
SEMTORTAL DI STrLCTS -- PLAN

Proposed senatomal Rodistrioting Based on the 1940

Consus and Deviation From the Qrota of 68,536.

Count1 es

Ho. of senators Deriation from

rake

Iake, Porter, Jasper, Mowt on

4

Laporte

st. Joseph

st. Jgsoph, Marshall, Pulton

E1khart

Iagrange, Steuben, Hoble, Dexalb

Alion

Alion, Thitley, Iosolusko

8tarko, Pulanid, White, Carroll, Benton 1

Cass, Man1

Tabash, Huntington, Wolls

Grant, Blackfora

Laums, Jay, Randolph

Deleware

Deleware, Honry, Rush

Incision

Indison, Hancock, sholby

Wayne, Unt on

Fayotte, Franklin, Deoatur, Riploy 1

Dearborn, Ohto switzerland, Jefferaon,

Clark, Jaokeon, scott,

Washington, Floyd, Harrison

Bartholomow, Brown, Monros

Porry, spencer, Dubole, Cranford

Iawronoe, Martin, Orange

Tanderburgh

Posey, o Ibaon, Warrick

P1ke, Davi ess, Groene

Inox, Sullivan

V1 80

Vigo, Clay, Owen

Iamion

Mart on, Hendri oka

Johneon, Morgan, Putnam

Vermilion, Tarren, Fountain, Parke

Tippocanoe, Eontgomery

clinton, Boone, Bamsition

Howard, TIpton

1

1

1

1

1

2

1

\section{J}

1.

1

1

1

2

1

1

1

1

1

1

1

1

1

1

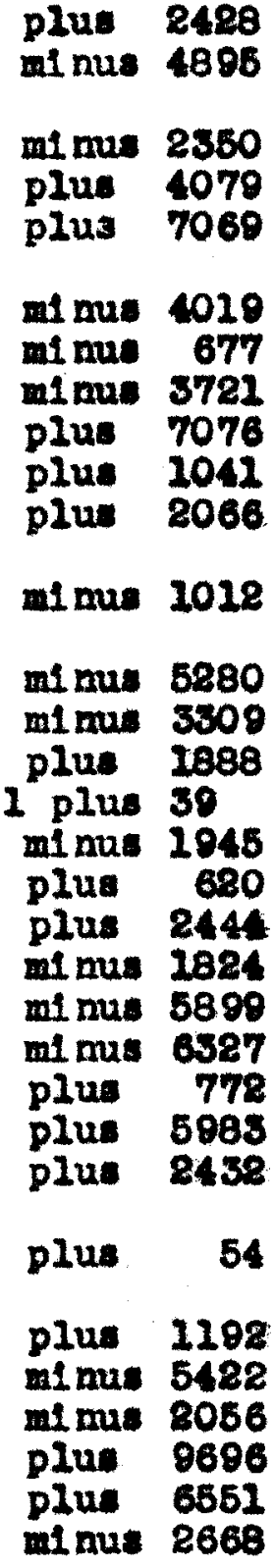




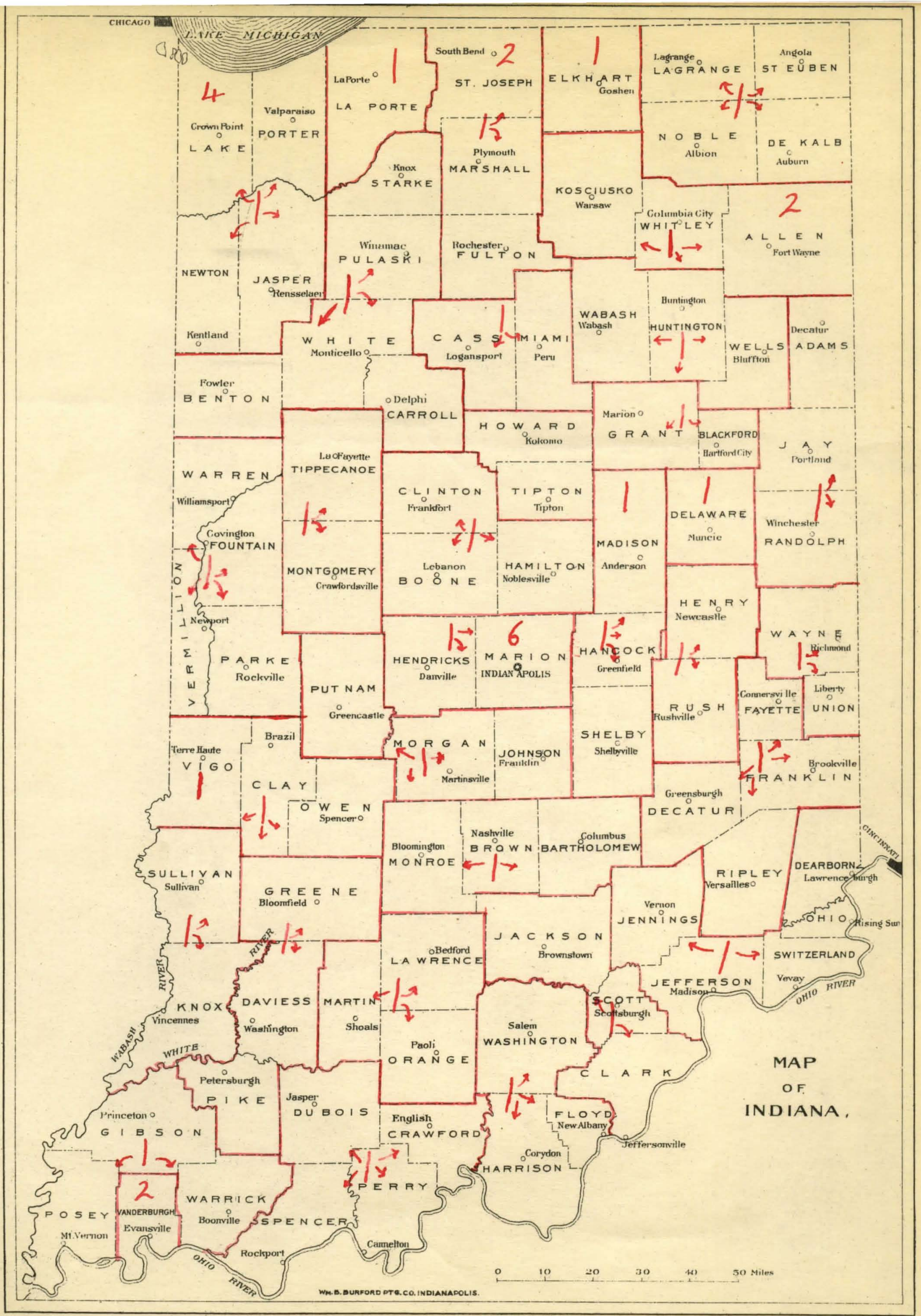


REPRESETTATIVE

Proposed Representative Redistrloting Based on 1940 Consus and Deviation From Quota of 34,277.

Oount1es

Do. of Ropresentative Deriati on Erom

Inse

Porter, Lales

Iaporte

St. Joseph

St. Joseph, Starke

Ellewart

Elkhart, Loselueko

Iagrange, Ioble

atouben, Doralb

Allon

Nilon, whitely

Marshel 1, Pulton

Iowton, Jusper, Pulask

Case

White, Oarroll

Il ppecanos

T1 ppecanos, Bent on

Howard

Foward, T1pton

Grant

Grant, Delaware

Delevary

Randolph

Indisoon

Indison, Hancook

Marion

Mert on, Hondriole

V180

Dearborn, Oht 0 , switsoriand

ILand

Wabech

Euntington

Wo12. Ndom

Blaokford, Jay

Verren, Vormililon

Fountain, Parike

C11 aton

Johnson, Morgan

Monroe

Lawronee

Froyd

Eonry

E onry, Unt on, Nayne

Rush, Pajette

8

1

8

4

1

2

1

1

1

4

2

1

2

1

I

1

2

2

2

1

1

2

1

8

$2 \frac{1}{13}$

1

3

2

1

1

I

1

2

1

1

1

1

2

1

1

1

1

Brown, Bartholomor suote

plue 2648

mit nus 4894

plue 2696

at nu 636

plus 0861

plus 4910

plue 700

plus 7ess

plus 2081

plue 2631

mi nue 1850

m1 nus 6420

nime 3667

al mu 6338

mi mus 7512

plus 5046

plus 1280

mima 3122

plus 78

it me 0351

plus 7676

plus 4346

plu 6076

plus 8207

Dif mas 0435

plus 2880

il mas 8866

plus 8017

plus 8257

plu 1768

plue 784

plu 2703

plus 4061

plue 288 
Iroposed Ropresentative Rodistrloting Based on 1940 Connus and Deriation From Quote of 34,877 . (Cont1 mued)

Oount1ea

Pranklin, Mipley

Jefferson, soott

Olark

Perry, 8ponoer

Tnox

Inox, Dartese

Q1ay

Owen, Putnom

Sulilvan

Groene

Vauderburgh

Vanderburgh, Poser

Vanderburgh, Warriok

Yont gomery

Boone, Fam12ton

Gibson

Sholby. Doeatur

Jokss on, Jonnl nga

Weshlngton, Harrison

Mertin, Orange, Orawford

Dubo1s: P1les
프. 오 Representatives Derlation Irom

Quote

intme 967

mimus $\mathbf{4 5 8 7}$

1 ma 3857

nimus 806

plus 2588

minu 8810

al ma 2348

milnus 7265

mi me 2047

m1 ma 1218

mimu 868

mimu 7048

plus 19418

inue 8668

plus 9589

plus 6025

mil mus 163

pla 1805

mi aus 5347 
Probable Polltical Party Ropresontation in the senate Under Plan 4 as Besed on Return of Eleotlon: of 1034 and 1938 .

countios Iare

Inle, Porter, Jasper, Lewton Democrat10 Repub110an Doubtrul

reporte $\mathbf{2}$

3t. Joseph

st. Joseph, Marmball, Fulton BIkbart

Iagrange, stouben, Moble, Derazb

1

AIIon

AIIon, Whitiog, Fosoluoke

starke, Pulaski, White, Carroll

Case, IItant

Nabein, Runt1ngton, Wo12

Grant, Blackford

Mdane, Jay. Randolph

Delavare

Deleware, Honry, Ruwh

Hedison

Yadison, Hancoek, Sholby

wayno, Union

pajette, Prankl1n, Decetur, RLploj I

Dearborn, Ohlo, swltzerland, Jefrerson, Jenninge

Ciark, Jukreon, soott

Vanblagton, Fiojd, Harrison

$\frac{1}{1}$

Bartholewow, Brown, Monros

Porxy, sponcer, Dubols, Crawford 1

Iawronce, Nartin, Orango

Vanderbures

Posey, asbon, Namidel 1

P1ke, Daviess, Oreene

2

1

Inox, Sullivan

$\nabla 180$

V180, O1ay, Owen

ramion

Yex on, Hondrick

Johna on, Horgan, Putnan

Tormilifon, Warren, Founta1n, Parke

1

1

Ilppoonoe, llontgomery

cilinton, Boons, Wuliton

Howard, Tipton

7

1

1

1 
In ne in the House Under Plan $\Delta$ as based on Returns Irom Blectlons or 1934--1938.

Count1es

Dato

Portor, rake

Iaporte

8t. Joseph

st. Joseph, Starico

Iurhart

ELchart, Kone1uako

Lagrange, Tob20

stouben, Doralb

Alion

Alien, Witioy

Iarahal1, Bulton

Howt on, Jueper, Puleskd

Cas:

White, Camroll

II ppocanoe

Ti ppocenoe. Benton

Eowara

Howard, Iipton

erant

Grant, Dolawase

Delamars

Randolph

redison

Madison, Hancook

marion

Iemi on, Bondry okw

$\nabla 1$ go

Doarborn, Ohlo, swtzorland i

nital

Wabash

Eunt I ngton

W118, Adema

Blackéro, Jay

Warren, Vormlilion

Fountain, Parke

cilntion

Jobnson, Morgan

Ionroe

Iawrence

Hord

Honry

Onlon, Bonry, Tegno

Tayne
Domoorat1o Republican Doubtrul 1

8
2

8

1

1

4

$\frac{1}{1}$

1

$\mathbf{2}$

1

1

$\frac{1}{1}$

8

18

1

3

1

2

1

1

1

$\frac{1}{1}$

$\frac{1}{2}$

$\frac{1}{1}$

1 
Wne Up in the Fowe Under Plan $A$ (Continued)

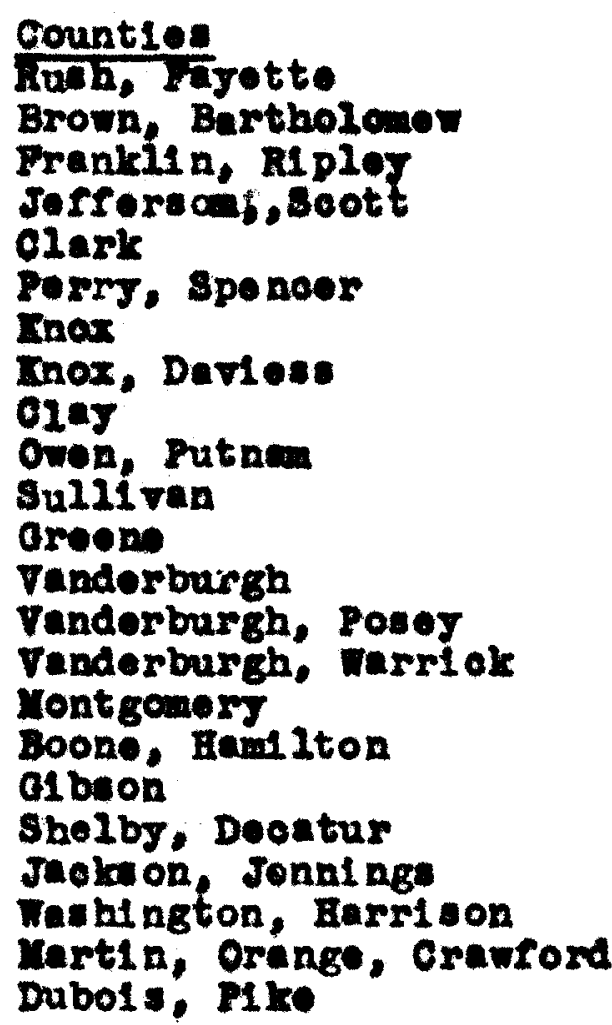

TOrAl
Demooratio Republioan Doubtrul

$\frac{1}{2}$
$\frac{1}{1}$
1

2

1

1

2

3

$\frac{1}{2}$

1

$\frac{1}{2}$

$\mathbf{1}$

1

1

1

1

1

$8 \%$

20

80 
Fgures Relative to Plan $A$.

SEMTR

Averago deviation from 1doal distriot 2136

number of perfect distriota 28

number of distriots orer 5000 of 1 deal $\theta$

number of diatriots Wthin 1000 of 1dend 23

Largeat deviation of ang one distriot 9696

H OUSE OF REPRESEWTATIVES

Average deviation frow ldoal di atriot $\quad 2007$

number of perfoet diatriets 47

Number of districts over 5000 of Iden 26

Number of distriots within 2000 of 1deal 9

Iargost deviation of any one detriot 12418. 
61

PIAN B

Proponod senatorlal Rodiatri oting Based on 1940

Consue and Doviation Iram Quota of 68535.

Oount1es

number of Senators $\frac{\text { Deriation Irom }}{\text { Dote }}$

rake, Porter, Jaeper, Elowton 6

Iaporte 1

8t. Joseph, Marshall, Fulton s

Bichart 1

Iagrange, Steubon, noble, Dokalb 1

Alion, Whit ioy, zoseluako

Starke, Fulaek, White, Carroll, Bonton 1

Case, itione

Nabaa h, Euntington, Wels

Grant, Blackfond

Adam, Juj, Randolph

Dolavare, Honry, Ruch

Yedison, Hanoook, sholby

Wayne, Unl on 1

Fayotte, Franklin, Decatur, Ripleyl

Doarborn, Ohl 0, 8iltzerland, Jof forson

1

Clark, Jeckenon, Seott and Jonni nga

Dantington, Ioyd, Farriaon

Bartholonew, Brown, Monroe

1

Perry, 8pencer, Dribols, Orawtord

Iawrenco, Martín, Orange

Vanderburgh

Poser, Giben, Farri ar

Pike, Davl ose, Oreone

Knox, sullivan

Vi go, Clay. Omen

Marl on, Hondri ok

Johnson, Dorgan, Putnem I

Vermililon, Farren, Fountaln, Park 1 Ti ppocanoe, Nontgomory

clinton, Boone, is emition

Eoward, Tlpton

$2_{1}^{2} 1$

plue 8498

ul mus 4898

m nus2380

plus 4079

plus 7069

minus 4020

minus 677

minus721

plus 7076

plus $204 x$

plue 2066

mi nus 2018

mi nus 5860

mings 3309

plus 2888

plus 39

minu 2045

plus 620

plus 244

minus 2884

minus 8800

minus 6327

plue $77 \mathrm{r}$

plus 5985

plue 2438

plus 54

plus 1192

minus 5422

mi mus 8056

plus 0606

plus 6551

mi nus 2663 


\section{PLAY B}

Proposed Bepresentatire Rodistrieting Based on 1940

Ceneus and Dorlation fram quote of 34,877.

Countios

Drankl1n, R1plog Jofferson, soott

Clark

Porry, Spencer

Inox, Davi eas

Clay

Oron, Putran

sulis van

Greon

Vandorburgh, Posej, warriok

Mont gomery

Boono, I anditon

- Ibeon

Sholby, Docetur

Jeokm on, Jonninge

Vaeblagton, Barrison

Martin, orange, crawford

Dubo1s, P1ke

Inke, Porter

Eaporte

St. Joseph, Starico

Elkhart, rosoluako

tagrange, Hoblo

steuben, Datralb

Milen, Ithitioy

Harebili, Fulton

Bewton, Jesper, Puleskd

Case

White, Carroll

II ppecance, Benton

Eoward, Tipton

Grant, Dolaware

Bandolph

Indison, Hanoook

narion, Eonameles

$\nabla 180$

Doarborn, Ohlo, swl teorland

Xian 1

Nabuah

Funtington

Wo11\%, Mdama
10. 으 Representat1vos Derlat1 on from Quote

mi nus 967

minus $\mathbf{4 6 8 7}$

minu $\mathbf{3 0 5 7}$

mi nus 206

plus 2688

minus 8818

mi nu 1348

mi mas 7265

minue 8047

mi nus 1984

mi me: 7046

plus 20418

nil nus 3568

plus 9898

plu: 6018

mimus 165

plue 2508

minus 5847

plus 8548

mi mu 4804

plus 2606

minu 686

pIus 8881

plue 4820

plue 700

plus 7256

plus 2031

plus 2631

mi mi: 1850

minus 6410

mimas $\mathbf{3 6 6 7}$

minus 6838

mi ma: 7612

plus 3046

plua 1209

in nus $\mathbf{5 1 2 8}$

plus 728

minus 6351

plus 7676

plus 4346

minus 6076 
(oontinued)

Counties

Blackford, Jay

varren, Vormilil on

Fountaín, Parles

clinton

Johns on, Morgen

Yonros

Iawrence

Ploye

Honry, Uni on, Tayno

Rush, payotte

Brown, Bartholomew
65

o. of Representatives Deviation frae

1
1
1
1
1
1
1
1
3
1
1

cuote

pirie 8107

minas 5450

plue 1880

minu: 5866

plus 8017

plua 2267

plu 176

plua 784

plu 2705

plus 4061

plus 288 
$63 \mathrm{~A}$

A close examination of Plans A and B d1soloses the fact that the figures remaln largely the oame. Each aection of the atate keops the same relative whare of the total representation of the state. The question to te decided botween the two plana resolves itself to thlswhich of the systons beat protecta the interesta of the umaller counties. This qusstion oan not be answered ontirely by looking at maps and flgurea. The element of political cuetom and campalen teohnlques must be conslder6a. Mether it is the oustom of the oandidate to lenore the swaller county and to concentrate all of his campalgnIng upon the larger county depends sometimes upon the local custon. In some districta, a small county, voting as a unit, sots noro consideratior from a candidate than the same population would rocelve if the cointj line was orased and the district noted as a unit.

As lons as the counity covernments remain as important polltivally as they now are, it would probably be Imposalble to prevent the people in the smaller countheo from foeling as if thoy were disenfranchised whon the smaller counties are lumped together with the larger countles. 
If the experience of the past is any indication of the future, the smaller counties will probably prefer to elect one joint Representative with the larger county and to let the larger county elect the others alone. To the student of government it makes little difference which plan is followed. The important point is that the public should have an opportunity to change the system at regular intervals. Apportionment is not an Act of the legislature, but the constant changing of representation to meet the shifts in the population. 


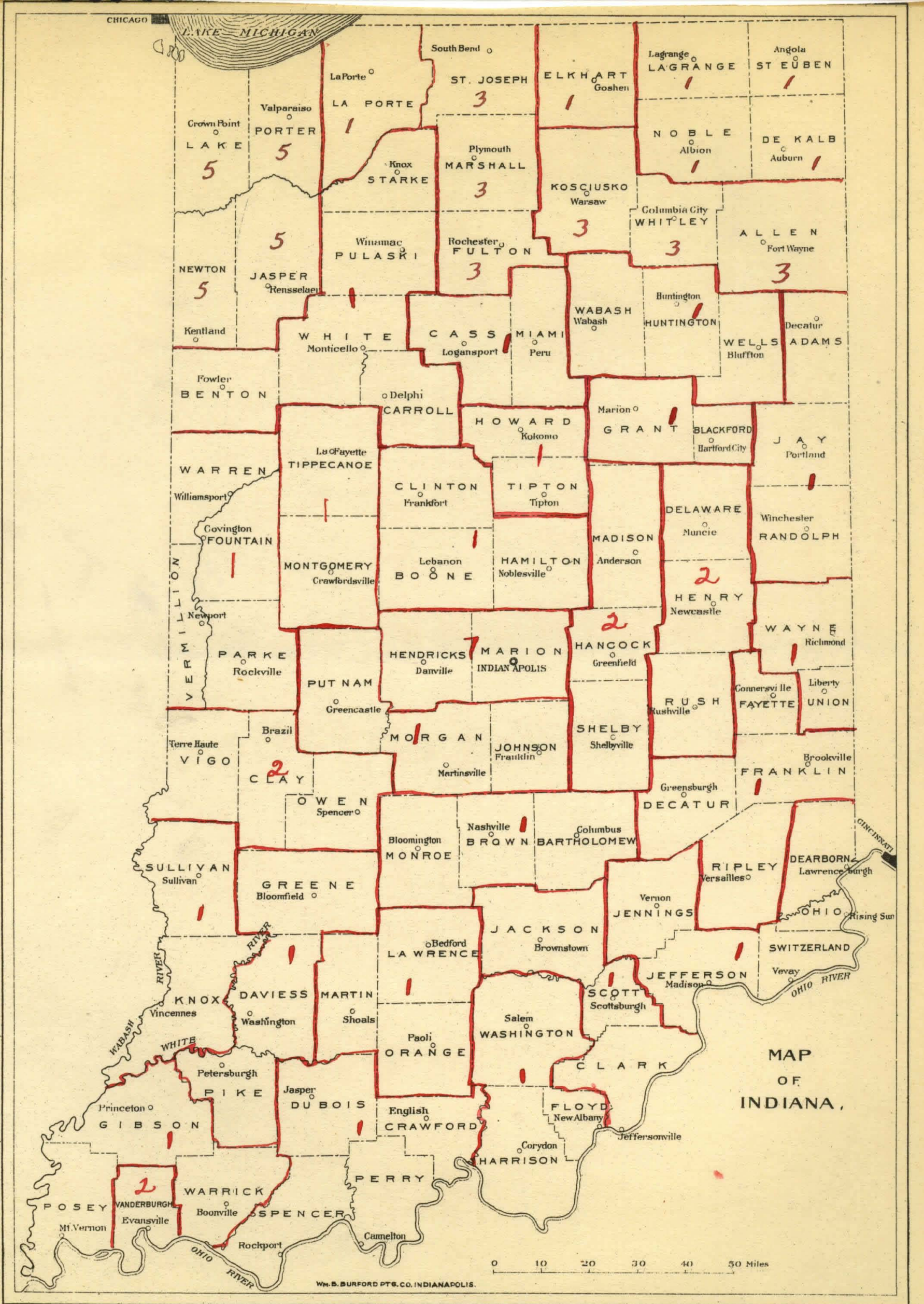


APPEDDTX A. 
TABLES RELATIVE TO POPULATION ARD PARTIES

Table 1.

Density of Population by Countios

County Lese than 100 yore than 100 Averace Populaper so. pille per ag. m110 tion per so. mile

Lama

21,232

59.8

Allon

154,833

288

Bartholomen 28,266

01.1

Benton

11,268

29

Blackerond

13,758

81

Boone

22,016

58

Brown

6,187

16

Carroll

14,730

38

Cases

38,393

83

clark

31,080

82

cley

25,167

73

clinton

28,300

67

Crawford

10,160

33

Dav1 exs

26,100

59

Dearborn

22,623

67

Dosatur

17,671

45

DakeIb

24,700

67

Delawaro

74,925

171

Dubo1.

22,543

48

Elkhert

72,488

149.1 
Table 1 cont.

County Los then 100 More than 100 Averege populeper sq. olle per so. mile tion per eq. mile

\begin{tabular}{|c|c|c|c|}
\hline Fayette & 19,386 & & 89.1 \\
\hline Floyd & & 35,048 & 234.8 \\
\hline Pountain & 18,308 & & 45.5 \\
\hline Frankl1n & 14,398 & & 36.8 \\
\hline Pulton & 15,241 & & 41 \\
\hline arbson & 30,662 & & 60 \\
\hline Grant & & 55,717 & 120 \\
\hline Greene & 31,205 & & 88 \\
\hline Bemiliton & 24,585 & & 58.8 \\
\hline Hencook & 27,248 & & 54.1 \\
\hline Herr1son & 17.101 & & 35.5 \\
\hline Hendrteks & 20,252 & & 48 \\
\hline Henxy & 40,168 & & 88 \\
\hline Howard & & 47,834 & 157.8 \\
\hline guntington & 29,648 & & 76 \\
\hline Jackson & 26,610 & & 46 \\
\hline Jaeper & 14,829 & & 23 \\
\hline Jey & 28,487 & & 56 \\
\hline Jefferson & 19,905 & & 52.7 \\
\hline Jonninge & 13,661 & & 30.8 \\
\hline Johnson & 28,448 & & 67.4 \\
\hline Knox & 43,865 & & 85.0 \\
\hline
\end{tabular}


Tablo 1 cont.

County Lese then 100 More then 100 Averege Populaper vo. mile por 10, milo

$$
29,483
$$

14,348

Lake

Laporto

Lawrence

Madison

Marion

Marahall

Martin

MI and

Monroe

Montgomery

Morgan

Newton

35,566

noble

Onio

Orange

Owon

Parke

Porry

P1ko

Porter
25,950

10,278

27,810

36,348

27, 267

18,798

10,989

22,734

3,764

17,199

12,158

17,353

17,025

27,697
17,765 tion per so. mile

50.8

35.6

288,283

631.1

63,658

201.7

78

88,002

184

456,660

$1,064.6$

56.8

29.8

76.8

86.5

63.9

47.8

24.5

53.7

44.1

48.9

28.0

37

43.3

48.4

65 
Tablo 1 cont.

\begin{tabular}{|c|c|c|c|}
\hline counts & $\begin{array}{l}\text { Lese than } 100 \\
\text { per eg. mile }\end{array}$ & $\begin{array}{l}\text { More than } 100 \\
\text { per eg. mile }\end{array}$ & $\begin{array}{l}\text { Average Popula- } \\
\text { tion por so. mile }\end{array}$ \\
\hline posey & 18,164 & & 44 \\
\hline Pulaskd & 12,057 & & 25.9 \\
\hline Putnom & 20,860 & & 42.3 \\
\hline Rendolph & 26,726 & & 85.6 \\
\hline RI pley & 28,851 & & 40.4 \\
\hline Ruah & 18,925 & & 47.5 \\
\hline 8t. Josaph & & 161,867 & 347.0 \\
\hline Scott & 8,072 & & 35.1 \\
\hline Shelby & 25,924 & & 65.8 \\
\hline Spencer & 16,800 & & 41.5 \\
\hline Sterice & 18,147 & & 34.8 \\
\hline Steuben & 13,700 & & 43.9 \\
\hline Sull1 van & 26,783 & & 61.8 \\
\hline switzerland & 8.264 & & 38.0 \\
\hline rippecanoe & 51,218 & & 94.4 \\
\hline ripton & 15,106 & & 58.5 \\
\hline Onlon & 6,023 & & 36.3 \\
\hline Vanderburgh & & 130,700 & 486.4 \\
\hline Vermi111 on & 21,763 & & 91.5 \\
\hline 180 & & 99.467 & 241.7 \\
\hline Wabesh & 26,568 & & 59.2 \\
\hline Narron & 9,033 & & 24.8 \\
\hline
\end{tabular}


38

mablo 1 cont.

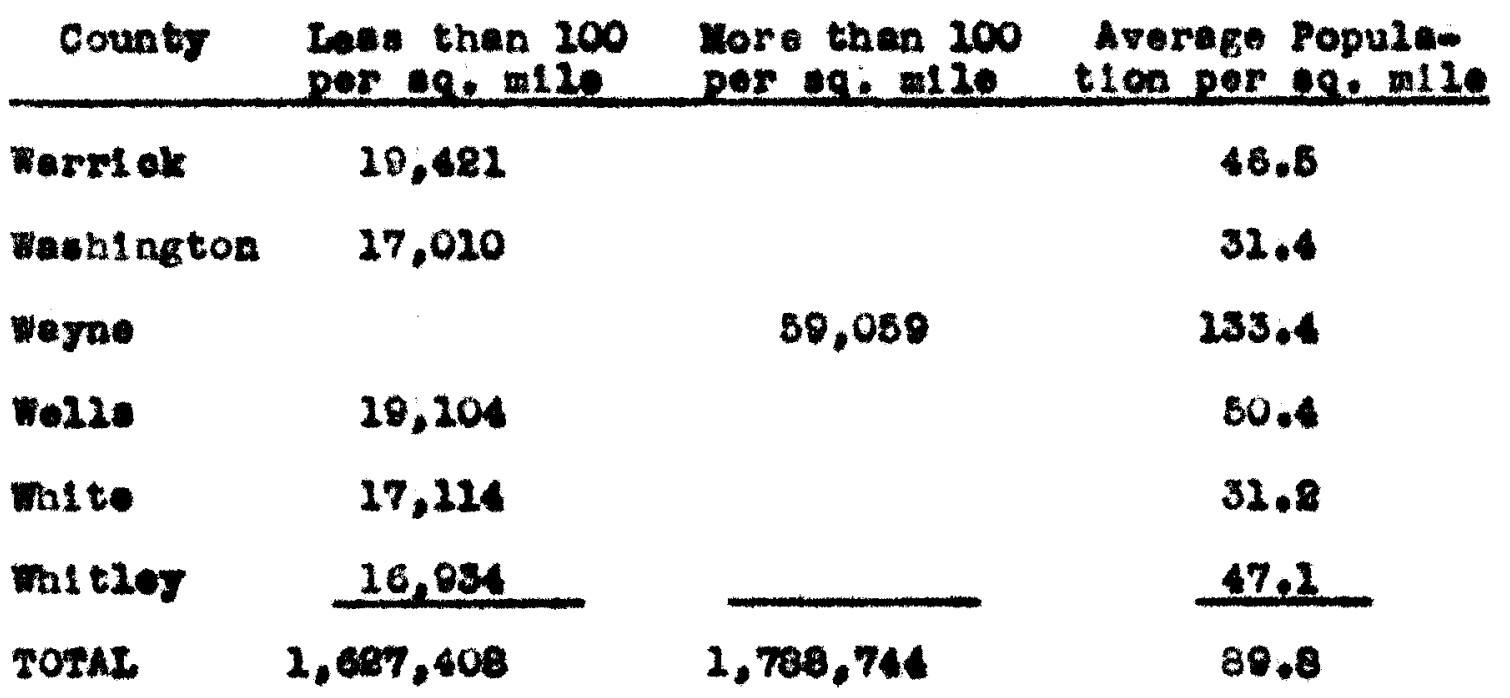


Tablo 8.

Abutract of vote for secretary of state, Novender 0, 1034

\begin{tabular}{|c|c|c|c|}
\hline Counts & $\begin{array}{c}\text { Auguet mueller } \\
\text { Degoerat }\end{array}$ & $\begin{array}{l}\text { Frod Noodwerd } \\
\text { Republioen }\end{array}$ & Resuzt \\
\hline Adam & 4.710 & 8,060 & Democret \\
\hline Allen & 27,067 & 23,760 & Denocret \\
\hline Bertholonew & 7.046 & 6,376 & Democrat \\
\hline Bention & 2,884 & 3,807 & Republl pan \\
\hline Bleckrond & 3,481 & $8,8 n$ & Domocret \\
\hline Boons & 6,144 & 5,661 & Democrat \\
\hline Brown & 1,400 & 1,198 & Democrat \\
\hline Carrol2 & 4,319 & 4,460 & Ropubl1 oan \\
\hline Case & 0.674 & 0,386 & Demoorat \\
\hline Clark & 8,678 & 0,230 & Demoorat \\
\hline cloy & 7,348 & 5,988 & Demoorat \\
\hline olinton & 7.748 & 7,253 & Demoarat \\
\hline Crentond & 8,602 & 2,360 & Denocret \\
\hline Daviees & 5,016 & 7.087 & Republionn \\
\hline Desrborn & 5,366 & 4,670 & Domoerat \\
\hline Decetur & 4.484 & 5,160 & Republioan \\
\hline Dexazo & 5,878 & 5,767 & Denoorat \\
\hline Deleware & 13,920 & 13,866 & Dowocret \\
\hline Dubole & 0,187 & 3,067 & Dowocret \\
\hline E2khart & 10,088 & 15,180 & Republioan \\
\hline Payette & 4,813 & 4,720 & Dewoorat \\
\hline
\end{tabular}


Table oont.

\begin{tabular}{|c|c|c|c|}
\hline county & $\begin{array}{c}\text { Auguat Muelior } \\
\text { Demoeret }\end{array}$ & $\begin{array}{l}\text { Frod woodwera } \\
\text { Republloep }\end{array}$ & Reeult \\
\hline Ploya & 8.450 & 6,804 & Dessocrat \\
\hline Fountein & 4,740 & 4,677 & Demooret \\
\hline Franklla & 3,682 & 3,021 & Denocret \\
\hline Duzton & 3,870 & 4.584 & Republioan \\
\hline OSbson & 7,082 & 7,206 & Demoorat \\
\hline Orant & 21,306 & 20,741 & Demoorat \\
\hline Oreene & 0,648 & 7,683 & Demoerat \\
\hline Hemilton & 4,860 & 6,838 & Republican \\
\hline Itenoook & 0,446 & 4,218 & Dowocrat \\
\hline garrison & 4,000 & 3,067 & Democrat \\
\hline Hendri oke & 4.006 & 5,083 & Repub21 onn \\
\hline Honry & 7.791 & 0,008 & Ropub21 oan \\
\hline Howerd & 10.174 & 0,582 & Demoorat \\
\hline Hunt ingtion & 7,136 & 7,088 & Domoorat \\
\hline Jacken & 0.523 & 4.041 & Denocrat \\
\hline Jeepor & 8,608 & 3,654 & Ropub110on \\
\hline Jay & 5,871 & 5,561 & Dewocrat \\
\hline Jerrereon & 4.006 & 8,460 & Republican \\
\hline Jennlngs & 5,214 & 3,652 & Republioan \\
\hline Johneos & 5,832 & 4,667 & Democret \\
\hline Knox & 21,601 & 0,037 & Democrst \\
\hline Kos o1 uske & 8,752 & 7,689 & Repub110an \\
\hline
\end{tabular}


71

Teble 2 cont.

\begin{tabular}{|c|c|c|c|}
\hline counb: & $\begin{array}{c}\text { Auguet unezler } \\
\text { Demooret }\end{array}$ & $\begin{array}{l}\text { Fred Roodrand } \\
\text { Republ10an }\end{array}$ & Rosult \\
\hline Loorange & 2.438 & 2.808 & Repulitioen \\
\hline Lake & 42.946 & 30,208 & Democest \\
\hline IePorto & 13,821 & 11,172 & Demooret \\
\hline Earrenes & 0.034 & 0,418 & Repub2s can \\
\hline Madson & 21.432 & 27.800 & Demoorat \\
\hline rerton & 90,306 & 77,822 & Dowosrat \\
\hline Narehn 12 & 8.007 & 6.809 & Dewoores \\
\hline Wentin & 2.583 & 2.786 & Republiens \\
\hline Ment & 7.680 & 6.772 & Domoeret \\
\hline Monros & 7.658 & 0.247 & Repubiloen \\
\hline Mortromers & 7.800 & 7.748 & Fepub11 on \\
\hline Horgan & 5,348 & 5.184 & Republ1 oen \\
\hline Newton & 8,384 & 9.086 & Republion \\
\hline Hov 20 & b.0m & 6.731 & Hepublion \\
\hline Onto & 1,078 & 1,021 & Dowoorat \\
\hline orange & 4.102 & 4.084 & Repubzloan \\
\hline Owen & 3.143 & 3,018 & Dewoeret \\
\hline Parke & 4.278 & 4.470 & nep:ab11 onn \\
\hline Parry & 4.440 & 3,583 & Demoorat \\
\hline Plko & 4.148 & 4.164 & Repub110an \\
\hline Portar & 4.042 & 5,830 & Nopublionn \\
\hline Poseg & 5,010 & 3,204 & Democrat \\
\hline
\end{tabular}


Table 2 cont.

\begin{tabular}{|c|c|c|c|}
\hline counts & $\begin{array}{c}\text { Auguat Wue } 2 \text { or } \\
\text { Demooret }\end{array}$ & $\begin{array}{l}\text { Fred noodware } \\
\text { Republloes }\end{array}$ & Reoult \\
\hline Pulack & 2.74 & 2,760 & Repubzloen \\
\hline Putnea & 6,648 & 4,600 & Denoerat \\
\hline Rendolph & 6,013 & 6,350 & Republloan \\
\hline Alpley & 6,286 & 4,808 & Denoorat \\
\hline Aus $b$ & 4,830 & 5,468 & Ropublioun \\
\hline gt. Joeeph & 88,074 & 29,086 & Republa can \\
\hline Scott & 2,040 & 2,020 & Democrat \\
\hline She 2by & 7,848 & 8,806 & Democret \\
\hline Epenoer & 0,028 & 4,728 & Democrat \\
\hline sterke & 8,024 & 2.797 & Demoorat \\
\hline steuben & 2,026 & 3,001 & Repub210an \\
\hline 8u2117an & 7,451 & 4,060 & Demoorat \\
\hline Switzeriand & 2.675 & 2,898 & Demooret \\
\hline Tippeosnoe & 30.696 & 18,086 & Republican \\
\hline IIpton & 4,461 & 3,870 & Democrat \\
\hline Union & 1,344 & 1.764 & Republlonn \\
\hline Venderburgh & 28,024 & 21,892 & Donoorat \\
\hline Vermi211 on & 5.751 & 4.540 & Demoorat \\
\hline$v_{180}$ & 20,007 & 17.030 & Democrat \\
\hline Wabash & 5,288 & 6,571 & Repubiloun \\
\hline werren & 2,164 & 2,008 & Republl oan \\
\hline Werrick & 4,433 & $=.0: 7$ & Dewocrat \\
\hline
\end{tabular}


Toble 2 oont.

\begin{tabular}{|c|c|c|c|}
\hline Counts & $\begin{array}{c}\text { Luguat Muel2er } \\
\text { Demoorat }\end{array}$ & $\begin{array}{l}\text { Prod Woodverd } \\
\text { Popub210an }\end{array}$ & Roov1t \\
\hline Wastangton & 4,012 & 3,376 & Demoarat \\
\hline *ะรnอ & 0,068 & 20,828 & Repub110en \\
\hline Ee210 & 5,842 & 3,420 & Denocrat \\
\hline White & 4.208 & 4,380 & Repub110en \\
\hline Whities & 4.839 & 3,057 & Democrat \\
\hline Torat & 738,487 & 688.437 & \\
\hline
\end{tabular}


Table 3.

Abatret of vote for seoretary or stete, Novenber 8, 1036 County goward D. Konnemann James $\mathrm{y}$. Tucker Renult Demooret Hepubzioen

\begin{tabular}{|c|c|c|c|}
\hline Adome & 4.746 & 3,020 & Demoorat \\
\hline Allon & 27,041 & 35,870 & Ropublloen \\
\hline Bartholowov & 7,294 & 7,658 & Republi oun \\
\hline benton & 2,617 & 3,213 & Republi oan \\
\hline Blenkford & 3,530 & 3.127 & Democrat \\
\hline Boons & 6,269 & 6,830 & Republioan \\
\hline Brown & 2,860 & 1,208 & Dowoorat \\
\hline Carroll & 4,268 & 4,686 & Repubzloan \\
\hline Cane & 0,308 & 0,980 & Republloan \\
\hline 02ark & 8,451 & 6,363 & Demoerat \\
\hline 0205 & 7,808 & 0,000 & Demoorat \\
\hline C21nton & 7,381 & 8,066 & Republioan \\
\hline crewrowa & 2,906 & 2,484 & Dowoorat \\
\hline Devienes & 6,563 & 7.878 & Republioen \\
\hline Dearborn & 8.879 & 4,606 & Demoorat \\
\hline Decetur & 4,728 & 5,282 & Republt ean \\
\hline Dexa1b & 6.080 & 0,102 & Ropub21anen \\
\hline Delavare & 15,426 & 18,313 & Repub2loan \\
\hline Dubole & 5,856 & 3,200 & Demooret \\
\hline Elikthert & 11,011 & 26,102 & Republi eas \\
\hline Payetto & 5,826 & 5,628 & Republican \\
\hline
\end{tabular}


Table 3 cont.

County Rdward D. Koonemane Jawes M. Tuoker Result Democret

Repubisean

\begin{tabular}{|c|c|c|c|}
\hline Ploya & 8.850 & 8.068 & Domoorat \\
\hline Pountala & 4,804 & 0.186 & Repubzioan \\
\hline Frank210 & 3,408 & 3,200 & Denoorat \\
\hline Prazton & 3,856 & 8.103 & Ropublioan \\
\hline Gibaon & 0,480 & 7.488 & Democrat \\
\hline Orant & 11.741 & 28,041 & Republioan \\
\hline Oreene & 0.066 & 8.007 & Desooret \\
\hline Bemiliton & 4.206 & 7.317 & Republioan \\
\hline Hancook & 5,27 & 4,436 & Demoorat \\
\hline Haxriaon & 4,600 & 4,200 & Demoorat \\
\hline Hendrt oke & 4,340 & 0,008 & Repub11 ean \\
\hline Henry & 7,060 & 20.283 & Republitoan \\
\hline Bownerd & 0,826 & 21,928 & Republ1 oan \\
\hline Euntington & 6,944 & 7,838 & Republi on \\
\hline Jrckeon & 6,774 & 6,382 & Demoorat \\
\hline Jaeper & 2,686 & $3, k 20$ & Republioen \\
\hline Jay & 6,703 & 6,004 & Republioan \\
\hline Jafferson & 4,660 & 5,833 & Republ1 ean \\
\hline Jenninga & 3,168 & 3,672 & Ropublioan \\
\hline Johneen & 5.074 & 5,651 & Domoorat \\
\hline Enox & 11,406 & 0,084 & Democrat \\
\hline Kos ol oulko & 5,050 & 8,482 & Ropublioan \\
\hline
\end{tabular}


Table soot.

County Idward D. Toencmann Jnme M. Tuoker Rosult Denoeret Repub110es

\begin{tabular}{|c|c|c|c|}
\hline Puleoki & 2,946 & 2,080 & Democret \\
\hline Putane & 6,820 & 5,006 & Demoorat \\
\hline Randolph & 4,602 & 0,080 & Republt can \\
\hline RLplor & 5,288 & 8,000 & Demoerat \\
\hline Aush & 4,280 & 0,468 & Ropublioan \\
\hline St. Joseph & 86,378 & 31,124 & Dewoorat \\
\hline soott & 2,834 & 8,006 & Denoorat \\
\hline Bnelby & 7,828 & 6,800 & Dessoorst \\
\hline Speneer & 4,474 & 6,240 & Republioan \\
\hline sterke & 2,806 & 3,000 & Republi ean \\
\hline steubon & 8,470 & 4.309 & nepubli ean \\
\hline sul117en & 8,080 & 6,380 & Domoerat \\
\hline Switzerlan & 8.688 & 2.060 & Domocrat \\
\hline IIppoonnes & 20,306 & 23,828 & Repub210an \\
\hline ripton & 4,887 & 4,321 & Republioan \\
\hline Unt on & 1,362 & 1,820 & Republloun \\
\hline Venderbures & 32,238 & 80,673 & Demoerat \\
\hline Vara1211 on & 6.873 & $4.6 n$ & Demoorat \\
\hline V180 & 84.098 & 18.480 & Demoeret \\
\hline wabash & 8,027 & 7.680 & Republi ean \\
\hline Warren & 1,776 & 2,006 & Repub11 onn \\
\hline werrek & 4,668 & 4,391 & Republionn \\
\hline
\end{tabular}


Tablo 3 eont.

County Sowerd D. Koenmmen Jewee H. Tucker Renult Domooset

Ropubileen

\begin{tabular}{|c|c|c|c|}
\hline Want ngton & 4.820 & 4.027 & Demooret \\
\hline Weyne & 0.064 & 28.390 & Republionn \\
\hline Fe12u & 4.813 & 0.014 & Demooret \\
\hline no1te & 4.106 & 4.828 & Republienn \\
\hline Wh1 tay & 1,280 & $\operatorname{s.680}$ & Ropubzioen \\
\hline Torax & 74,805 & 778,844 & \\
\hline
\end{tabular}


Tab2e 4.

Rumber of Mo20 Inhabitants Enumeret In 1020 and Quote ' for Apportionment of Representetives Based on These Pleureu

\begin{tabular}{|c|c|c|}
\hline County & $\begin{array}{l}\text { Wa } 20 \text { Inhobitante } \\
\ln 2010\end{array}$ & Percentile Quote \\
\hline ram & 4,070 & .676 \\
\hline Al2on & 27,008 & 3.804 \\
\hline Bartholomon & $6,7 r$ & .700 \\
\hline Eenton & 3,501 & .380 \\
\hline Blackfond & 3,757 & .454 \\
\hline Boons & 7,066 & .770 \\
\hline Browa & 1,686 & .190 \\
\hline Carroll & 4.066 & .054 \\
\hline Cese & 11,205 & 1.248 \\
\hline olark & 7,864 & .058 \\
\hline clay & 8,807 & .000 \\
\hline Cilnton & 0,005 & .008 \\
\hline Orewtord & 2,062 & .326 \\
\hline Dev I ese & 6,668 & .810 \\
\hline Denrborn & 0,320 & .678 \\
\hline Deoetur & 8.601 & .698 \\
\hline Dexa2b & 7,360 & .700 \\
\hline Doleware & 26,243 & 1.856 \\
\hline Dubole & 5,161 & .618 \\
\hline S1khart & 28,897 & 1.048 \\
\hline
\end{tabular}


Table 4 cont.

\begin{tabular}{|c|c|c|}
\hline Counts & $\begin{array}{l}\text { Wole Inhebl tente } \\
\text { in } 1020\end{array}$ & Peroentile Quota \\
\hline Pajette & 4,788 & .636 \\
\hline Ploga & 8.521 & 1.008 \\
\hline Fountaln & 6,641 & .628 \\
\hline Frank21n & 4,368 & .548 \\
\hline Puiton & 4,802 & .824 \\
\hline asben & 0,388 & 2.086 \\
\hline orent & 24,427 & 1.688 \\
\hline Areene & 0,087 & 2.206 \\
\hline Eami Iton & 7,058 & .804 \\
\hline Henoook & 5,572 & .598 \\
\hline Earricon & 4,088 & .538 \\
\hline Benarl eke & 6,710 & .066 \\
\hline Honry & 0,588 & 2.216 \\
\hline Howard & 28,058 & 2.410 \\
\hline Hunt ington & 8,400 & 1.048 \\
\hline Jeolnon & 6,430 & .736 \\
\hline Jasper & 3,868 & .434 \\
\hline Jay & 6.674 & .744 \\
\hline Jertereon & 5,840 & .058 \\
\hline Jonningu & 5.811 & .400 \\
\hline Johneon & 6,360 & .674 \\
\hline Knox & 10.007 & 2.384 \\
\hline
\end{tabular}


Table 4 cont.

\begin{tabular}{|c|c|c|}
\hline Counts & $\begin{array}{l}\text { Yalo Inhubitante } \\
\text { in } 1919\end{array}$ & Percent110 Quote \\
\hline Kos ol ousko & 7,074 & .898 \\
\hline LeGrange & 3,751 & .488 \\
\hline Lake & 46,825 & 7.344 \\
\hline Laporto & $13,7 \cup 9$ & 1.686 \\
\hline Lawrence & 7,365 & .978 \\
\hline Madison & 18,778 & 2.194 \\
\hline Marton & 93,878 & 28.250 \\
\hline Marshall & 6,437 & .740 \\
\hline Mertin & 2,861 & .310 \\
\hline II am & 8,306 & .082 \\
\hline Monroe & 6,217 & .014 \\
\hline Montgomery & 8,741 & .826 \\
\hline Morgan & 6,013 & .666 \\
\hline Wevton & 2,038 & .318 \\
\hline Noble & $6,6 \cup 7$ & .786 \\
\hline Ohio & 1,305 & .150 \\
\hline Orange & 5,234 & .556 \\
\hline Omen & 3,648 & .408 \\
\hline Parko & 5,346 & .602 \\
\hline Perry & 4,048 & .474 \\
\hline Plke & 5,050 & .610 \\
\hline Porter & 5,741 & .728 \\
\hline
\end{tabular}


Table 4 cont.

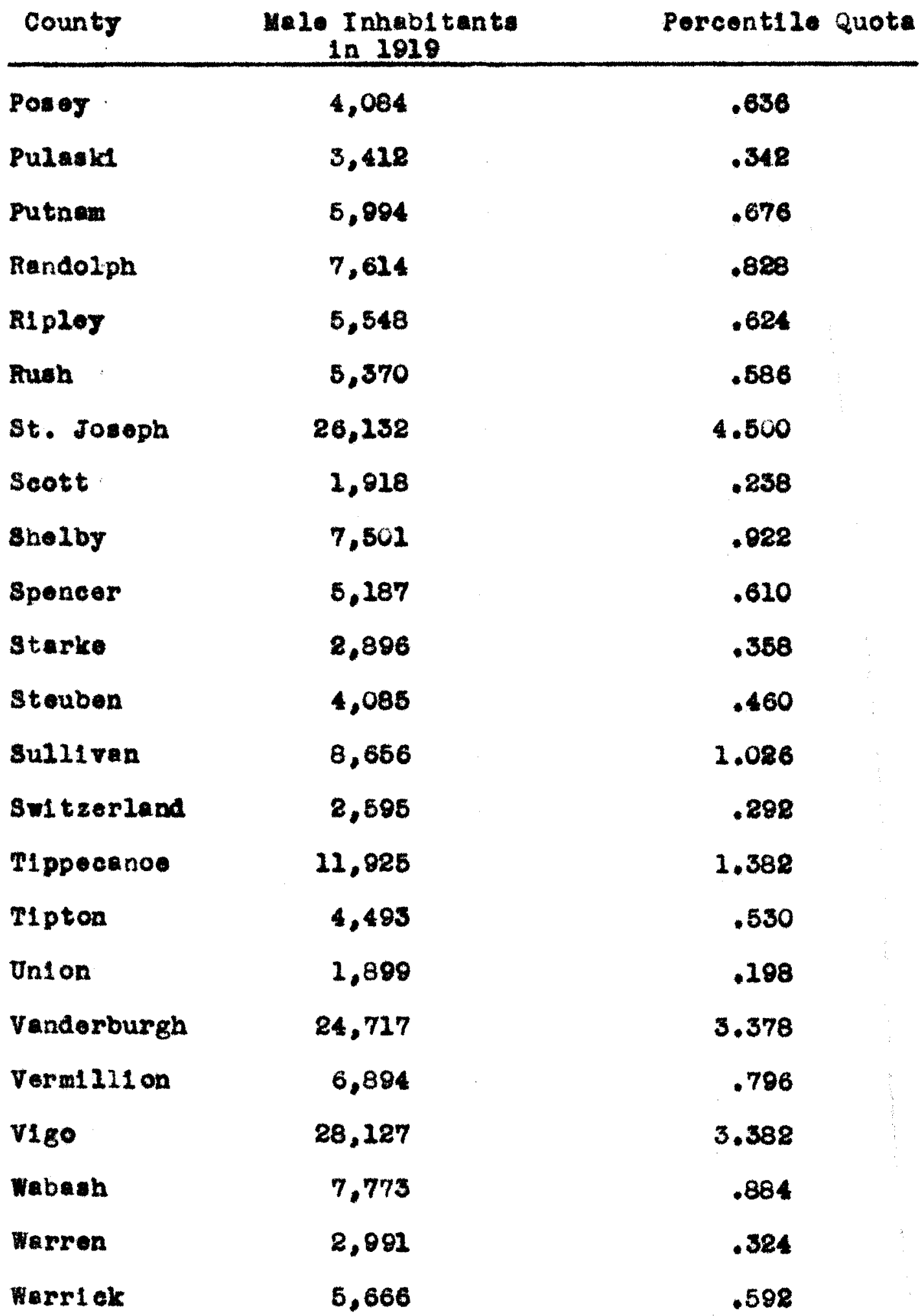


Table 4 oont.

\begin{tabular}{|c|c|c|}
\hline counts & $\begin{array}{l}\text { Walo Inbab1 tentes } \\
\text { In } 1029\end{array}$ & Peroent!2o Quota \\
\hline Washlagton & 4,586 & .470 \\
\hline vagne & 23,834 & 2.734 \\
\hline We110 & 0,003 & .648 \\
\hline whit to & 4,880 & .584 \\
\hline miterey & 4,828 & .500 \\
\hline TOMAL & 800,748 & 100.00 \\
\hline
\end{tabular}


Table 5.

Popular Vote for Preeldent in Indiana in 1936

county

Roosevelt

Democrat

Adama

Allen

Bartbolomew

Banton

Blackford

Boone

Brown

Carrol1

Casa

Clark

Cley

Cilnton

Crewford

Deviose

Den rborn

Docetur

DexaIb

Delamare

Dubol.

Elkhert

Fayotto
5,822

39,151

8,536

3,821

4,217

6.775

1,586

4,676

20,478

10,116

8,235

8,340

2,818

6,848

6,366

6,087

6,870

19,048

6,027

14,473

5,756
Iandon Republioan

$$
3,240
$$

24,766

6,484

2,880

2,845

5,730

1,244

4,426

8,528

5,536

6,335

7,265

8,589

6,458

4,660

4,887

5,848

14,207

3,011

14,896

5,067
Reault

Dewoorat

Democrat

Demoorat

Domoerat

Denoerat

Demooret

Domocrat

Demoorat

Democret

Demoorat

Democrat

Democret

Democrat

Democrat

Democrat

Democrat

Democrat

Democrat

Democrat

Ropublican

Domocrat 
Table 5 cont.

\begin{tabular}{|c|c|c|c|}
\hline County & $\begin{array}{l}\text { Roosevelt } \\
\text { Domocrat }\end{array}$ & $\begin{array}{c}\text { Zandon } \\
\text { Repub11 oen } \\
\end{array}$ & Rosult \\
\hline Ployd & 10,654 & 6,876 & Domocrat \\
\hline Pounteln & 5,771 & 4,663 & Democrat \\
\hline Frank11n & 3,802 & 2,858 & Democrat \\
\hline Fulton & 4,328 & 4,541 & Republloan \\
\hline a1bson & 9,398 & 7,078 & Domocrat \\
\hline Orant & 13,655 & 12,774 & Democrat \\
\hline Oreene & 9,730 & 7,460 & Demoerat \\
\hline Hami Iton & 5,396 & 7,323 & Republ1ean \\
\hline Hancock & 5,862 & 4,274 & Demoorat \\
\hline Earrison & 5,085 & 3,885 & Denocrat \\
\hline Eondrt oke & 5,237 & 5,776 & Republ1can \\
\hline Benry & 10,172 & 8,098 & Demoerat \\
\hline Howard & 12,888 & 9,634 & Democrat \\
\hline Huntington & 8,361 & 7,024 & Domocrat \\
\hline Jackaon & 8,018 & 4,851 & Democrat \\
\hline Jaspor & 3,100 & 3,540 & Republioan \\
\hline Jay & 6,635 & 5,835 & Democrat \\
\hline Jefferson & 4,808 & 5,320 & Republican \\
\hline Jenninge & 3,167 & 3,594 & Republioen \\
\hline Johnuon & 6,934 & 5,315 & Democrat \\
\hline Knox & 13,669 & 8,580 & Domocrat \\
\hline Kosclusko & 6,800 & 8,182 & Republioan \\
\hline
\end{tabular}


Tablo 5 cont.

\begin{tabular}{|c|c|c|c|}
\hline Counts & $\begin{array}{l}\text { Rooserelt } \\
\text { Democret }\end{array}$ & $\begin{array}{c}\text { Landon } \\
\text { Republeen }\end{array}$ & Result \\
\hline Orange & 2,821 & 3,125 & Republioan \\
\hline ake & 68,562 & 33,689 & Domocrat \\
\hline aporte & 15,550 & 12,728 & Demoorat \\
\hline arrenoe & 8,062 & 9,982 & Republican \\
\hline adion & 27.347 & 16,644 & Demoorat \\
\hline arton & 184,061 & 87.798 & Demoorat \\
\hline $\operatorname{arsha} 11$ & 0,651 & 6,118 & Domocrat \\
\hline artin & 2,083 & 2,603 & Democrat \\
\hline I end & 8,173 & 6,747 & Lomoerat \\
\hline onroe & 9.220 & 8,842 & Demoorat \\
\hline ontgomery & 8,053 & 7,360 & Demoernt \\
\hline organ & 5,461 & 5,793 & Republiean \\
\hline owton & 2,430 & 2,937 & Ropublican \\
\hline oblo & 5,880 & 5,760 & Domoerat \\
\hline hio & 1,362 & 1,028 & Demoerat \\
\hline range & 4,549 & 5,106 & Demoorat \\
\hline won & 3,488 & 3,001 & Demoerat \\
\hline arke & 4,811 & 4,686 & Demoorat \\
\hline orry & 4,782 & 3,610 & Demoorat \\
\hline $1 k e$ & 4.952 & 3,886 & Democrat \\
\hline orter & 5,560 & 6.278 & RepubI1ean \\
\hline osey & 5,630 & 3,088 & Democrat \\
\hline
\end{tabular}


Table 5 cont.

\begin{tabular}{|c|c|c|c|}
\hline counts & $\begin{array}{l}\text { Roosevelt } \\
\text { Domoorat }\end{array}$ & $\begin{array}{c}\text { Lendon } \\
\text { Ropublione } \\
\end{array}$ & Result \\
\hline Pulaskl & 3,274 & 2,780 & Donocrat \\
\hline Putnam & 6,177 & 4,961 & Domocrat \\
\hline Randolph & 6,487 & 6,688 & Republioal \\
\hline Ripley & 5,546 & 4,119 & Demoorat \\
\hline Rusb & 5,559 & 5,467 & Demoorat \\
\hline St. Joseph & 43,151 & 85,807 & Demooret \\
\hline$S \cot t$ & 2,696 & 2,054 & Domoorat \\
\hline Shelby & 8,558 & 6,026 & Denocrat \\
\hline Speneer & 4,066 & 4,567 & Democrat \\
\hline Starke & 3,243 & 2,846 & Democrat \\
\hline Sullivan & 10,203 & 4,685 & Democrat \\
\hline switzerland & 2,840 & 2,218 & Democrat \\
\hline Tippecanoe & 12,732 & 13,081 & Ropublioan \\
\hline T1 pton & 4,786 & 3,842 & Democrat \\
\hline Union & 1,668 & 1,630 & Demoerat \\
\hline Vanderburgh & 41,490 & 14.785 & Demoorat \\
\hline Vermililion & 7,188 & 4,320 & Democrat \\
\hline V1go & 33,018 & 17,278 & Democrat \\
\hline Wabaen & 6,800 & 7,223 & Republ1 can \\
\hline Darren & 2,248 & 2,780 & Republioen \\
\hline Warrick & 5,343 & 3,968 & Democrat \\
\hline Wastington & 4.766 & 3,690 & Denocrat \\
\hline
\end{tabular}


3

Table 5 cont.

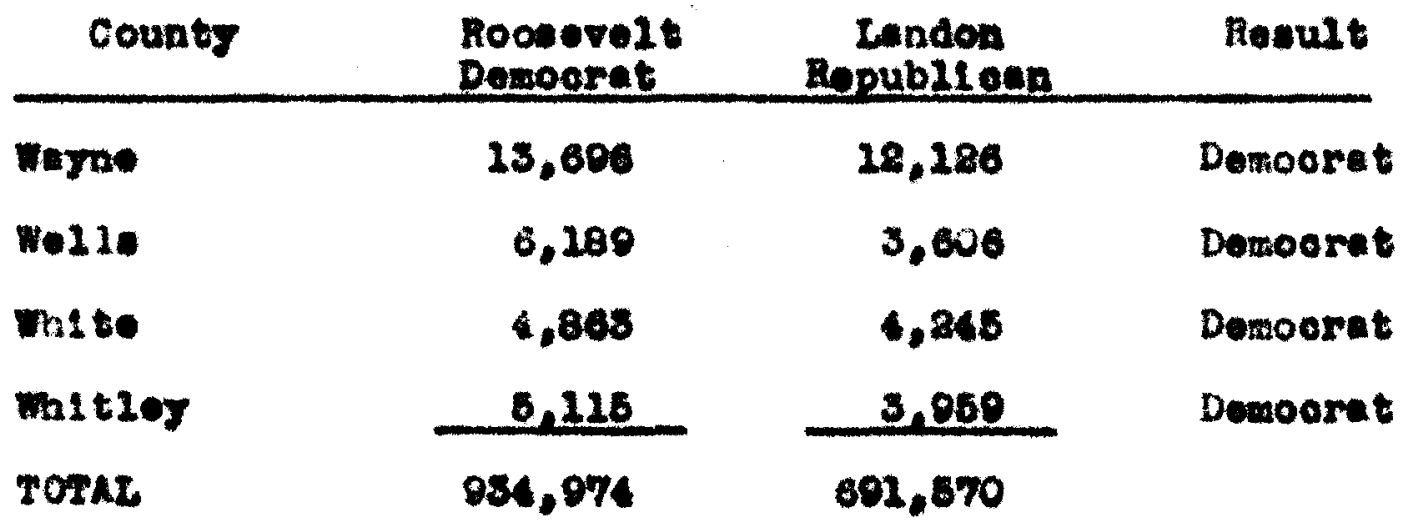


Table 6.

Popular Vote for President in Indian in 1840

\begin{tabular}{|c|c|c|c|}
\hline County & $\begin{array}{l}\text { Roosevelt } \\
\text { Domoerat }\end{array}$ & $\begin{array}{c}\text { wilki } \\
\text { Ropubiloen }\end{array}$ & Result \\
\hline Adams & 4,388 & 5,247 & Republ1 oan \\
\hline Alion & 30.456 & 40,421 & Republ1 can \\
\hline Bartholomew & 8,180 & 7,800 & Domoerat \\
\hline Benton & 2,680 & 3,675 & Republi oan \\
\hline Ble okford & 4,095 & 3,358 & Democrat \\
\hline Boone & 6,152 & 7,060 & Republioan \\
\hline Brown & 2,662 & 1,477 & Democrat \\
\hline Cenroll & 4,213 & 5,012 & Ropublionn \\
\hline Cass & 10,268 & 10,057 & Democrat \\
\hline clark & 9,015 & 6,044 & Domocrat \\
\hline Clay & 7,255 & 7,768 & Republican \\
\hline Clinton & 7.738 & 8,610 & Republican \\
\hline Crewrord & 2,836 & 2,662 & Democrat \\
\hline Daviena & 6,401 & 7,616 & Ropubl:oan \\
\hline Dosrborn & 6,038 & 5,808 & Democrat \\
\hline Decetur & 4,463 & 6,087 & Ropubli oan \\
\hline Dexalb & 5,600 & 7,676 & Republi oan \\
\hline Deleware & 20,836 & 17,616 & Democrat \\
\hline Dubo1s & 5,998 & 4,729 & Democret \\
\hline Blthert & 13,620 & 10,735 & Republican \\
\hline Feyette & 5,448 & 5,567 & Republican \\
\hline
\end{tabular}


reble 6 cont.

\begin{tabular}{|c|c|c|c|}
\hline County & $\begin{array}{l}\text { Hooserolt } \\
\text { Demooret }\end{array}$ & $\begin{array}{l}\text { Wikte } \\
\text { Republioen }\end{array}$ & notuzt \\
\hline Floyd & 10.700 & 8.086 & Demoorat \\
\hline Founteln & 4.783 & 0.772 & Repub210en \\
\hline Pranklin & 3,148 & $4,3.1$ & Repub210an \\
\hline Fuiton & 3,870 & 5.538 & Republl oas \\
\hline 010000 & 8,700 & 8,380 & Demoorat \\
\hline Orant & 13,268 & 26,180 & Ropublioen \\
\hline orsene & 8,718 & 8.072 & Repub2lonn \\
\hline Haw 1 Lton & 4.701 & 0.031 & Republi oan \\
\hline Eencook & 5,427 & 8,208 & Demoeret \\
\hline Garrieon & 4,788 & 4.680 & Dasoeret \\
\hline Bendri oke & 4,888 & 6,782 & Repub2tan \\
\hline Heary & 9,623 & 21,082 & Fepub2l oan \\
\hline Howard & 28,686 & 12,856 & Demoerat \\
\hline funt1 ngton & 7,280 & 9,110 & Repubzi oan \\
\hline Jeskew on & 7.686 & 0,273 & Dewoerts \\
\hline Jesper & 2.781 & 4,468 & Hopub21 oen \\
\hline Jay & 6,684 & 6,478 & Damoorat \\
\hline Jesterson & 4.680 & 0.067 & Republl oan \\
\hline Jenrisnge & 8,089 & $3,0 \mathrm{R1}$ & Repub 11 oun \\
\hline Johneon & 8,288 & 6,481 & Kepublioen \\
\hline Xnox & 18,285 & 11,206 & Demoorat \\
\hline Xosctueko & 5,888 & 0,878 & Republl ean \\
\hline
\end{tabular}


foblo o cont.

\begin{tabular}{|c|c|c|c|}
\hline County & $\begin{array}{l}\text { Roosevelt } \\
\text { Domocret }\end{array}$ & $\begin{array}{c}\text { Wilkie } \\
\text { Republicen }\end{array}$ & Result \\
\hline Laorange & 2.184 & 3,731 & Republioan \\
\hline Lalre & 71,086 & 45,898 & Democrat \\
\hline Leporte & 13,738 & 15,772 & Republican \\
\hline Lavrence & 6,653 & 10,727 & Republi can \\
\hline Medison & 26,112 & 22,398 & Democrat \\
\hline Marion & 181,803 & 124,848 & Republican \\
\hline Mf rahall & 5,868 & 7,718 & Repub11oan \\
\hline Martia & 2,638 & 2,008 & Republican \\
\hline Mlami & 7,258 & 8,217 & Repub110en \\
\hline Monroe & 8,127 & 10.311 & Republican \\
\hline Montgomery & 6,994 & 8,654 & Republ1 oan \\
\hline Morgan & 4.806 & 6,613 & Republ1can \\
\hline Hewton & 2,150 & 3,518 & Republican \\
\hline Hoble & 5,010 & 7,343 & Ropublican \\
\hline Ohio & 1,210 & 1,186 & Demoerat \\
\hline Orange & 4.003 & 5,510 & Republioen \\
\hline Owen & 3,121 & 3,700 & Ropublican \\
\hline Pariko & 4,384 & 5,242 & Republioen \\
\hline Perry & 4,476 & 4.480 & Republican \\
\hline Plke & 4,449 & 4,672 & Republ1oen \\
\hline Porter & 5,780 & 8,270 & Republicon \\
\hline Poseg & 5,028 & 4,514 & Demoorat \\
\hline
\end{tabular}


Table 6 cont.

County
Roosevelt Demooret winde Republican

Pulask1

Putnan

Randolph

Ripley

Fuab

\$t. Joseph

scott

Shelby

Spencer

Starke

Stoubon

Suz21 von

Switzorland

TIppecanoe

Tipton

Un1 on

Vandarburgh

Vermill1 on

vigo

Wabash

Werren

warriok
3,023

6,020

5,787

4,834

4,282

45,620

2,650

0,015

4,180

2,817

2,524

8,687

2,658

12,120

4,173

1,415

38,567

6,174

$29,3 \cup 8$

5,342

1,827

5,019
3,498

5,834

8,033

6,061

36,164

2,280

7,216

5,667

3,473

5,056

6,654

2,285

16,148

4,748

2,009

28,417

5,714

23,177

8,755

2,899

5,456
6,486
Rosult

Republl can

Democrat

Republican

Republican

Republican

Democret

Democrat

Democrat

Ropublican

Republican

Republican

Democrat

Domocrat

Ropublican

Republicen

Ropublioan

Democrat

Democret

Demoerat

Republ1 can

Republican

Republican 
93

Table 6 cont.

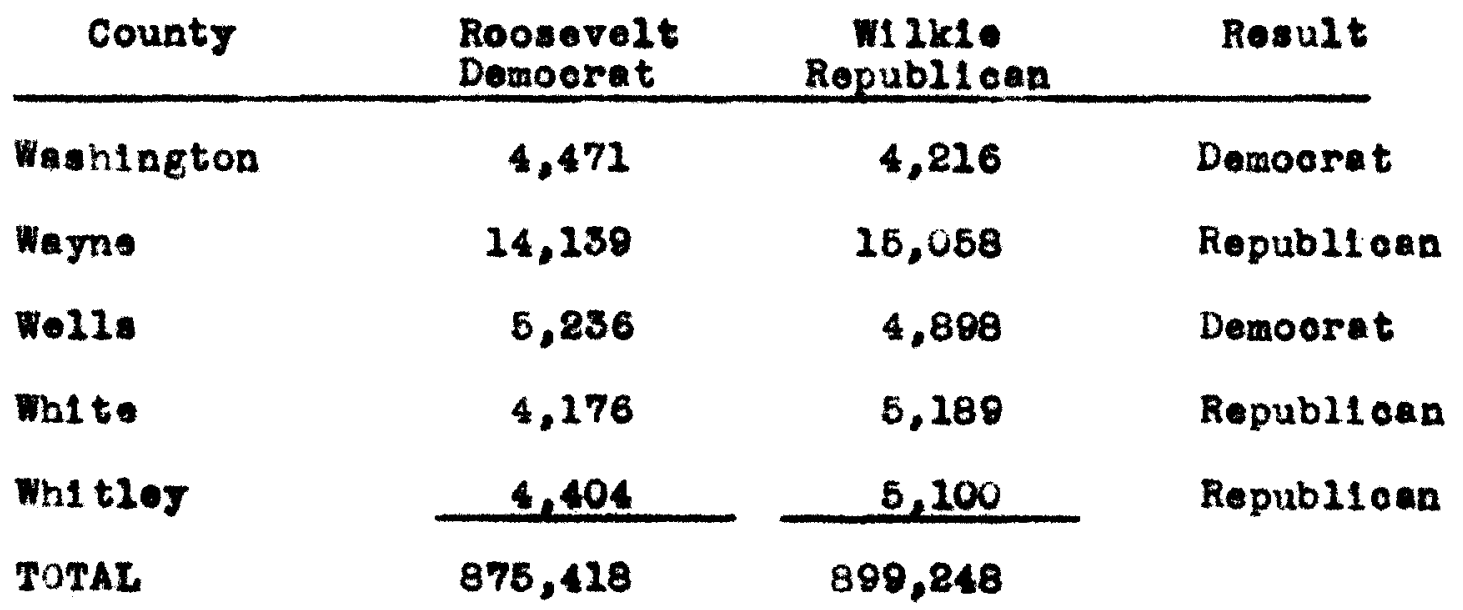


Teble 7.

Change in Populetion between 1920 and 1940

county

1940

1920

Net Change

\section{Adems}

Allen

Bartholomew

Eenton

Elackford

loono

Brown

Carroll

Cass

laxk

clay

dinton

Grawford

Daviess

Deerborn

lecatur

Deralo

Delaware

ubols

ikhart

Feyette

Floyd

Fountain
21,232

154.833

29,266

11,262

$13,75 \mathrm{~B}$

22,016

6,187

14,730

38,393

$31, \cup 2$

25,10

28,300

10,160

$26,1 \cup$

20,623

17,671

24,709

74,825

22,543

72,488

19,385

35,048

$18,3 \cup 8$
20,503

114,303

23,887

12,200

14,084

23,575

7.018

16,315

38,333

29,381

29,447

27.737

11,201

26,50

20.033

17,013

25,600

$56,37 \%$

19,815

56,384

17,142

30,661

18,823
728

40,530

4,379

944

326

1459

832

1,585

bu

1.039

4,280

503

1,041

750

0.580

142

819

18,548

2,028

16,104

2,253

4,387

515 
Table 7 cont.

orunt

1.40

1820

Net Change

\begin{tabular}{|c|c|c|c|}
\hline Frenklin & 14,350 & 24,800 & $4 \cup 8$ \\
\hline Fuzton & 15,541 & 10,470 & 537 \\
\hline albson & 30,602 & $29,2 \cup 1$ & 1,401 \\
\hline Grant & 56.717 & 51,353 & $4,0 \cup 4$ \\
\hline Greene & 31,293 & 36,770 & 5,477 \\
\hline Vem? Iton & 26,585 & 24.222 & 363 \\
\hline incook & 17,248 & 17,210 & 32 \\
\hline Herrison & 17,101 & 10,050 & 1,556 \\
\hline Fondrlcks & 20,252 & 20,291 & 138 \\
\hline nenry & 40.162 & 34,082 & 5,480 \\
\hline Towf rd & 47,834 & 43,965 & 3,869 \\
\hline Untinoton & 29,842 & 31,071 & 1,820 \\
\hline Jackson & 20,010 & 24,228 & 2,382 \\
\hline Jaspor & 14.029 & 13,801 & 868 \\
\hline $\operatorname{sag}$ & 22,487 & 23,320 & 931 \\
\hline vefforson & $1 ., 805$ & $20,7 \cup 8$ & $8 \cup 4$ \\
\hline Jonnlngs & $13, \ldots 1$ & 13,280 & 381 \\
\hline Jonnson & 22,488 & 20,738 & 1,740 \\
\hline Krox & $43,8 \cup 5$ & 40,195 & 2,330 \\
\hline Kogetusko & 26.483 & 27,220 & 2,363 \\
\hline Lasrenge & 14,348 & 14.000 & 330 \\
\hline Lako & 280,283 & 158,057 & 128,326 \\
\hline Laporte & 03,658 & 50,443 & 13,215 \\
\hline Lawrence & 35.554 & 26.228 & 7,328 \\
\hline
\end{tabular}


Table 7 cont.

county

1840

1820

Not Chango

sadison

85,082

08.151

18,941

ver:on

450,000

348,061

108,008

Mers hall

25,950

23.744

2.200

sereln

10,278

11.805

1,587

Wlaml

27,810

28,008

858

Monroe

30,348

24,519

1,028

yontgonery

27.810

28,490

1,223

Forger

19.795

20,010

212

Newt on

10,080

10.244

845

Noble

27.734

22,470

5.264

Thso

3,764

4.024

200

Oranee

27.189

20.974

225

Jwen

12,158

12,700

602

Prke

17,353

18,878

1.528

Porry

$27.76 \mathrm{~s}$

10,082

1.073

zlke

17.025

18.684

1.659

porter

27.967

20,256

7.721

posey

18,164

29,334

170

Pulaek1

12.067

12,385

328

Putnom

20,800

19.880

860

randolph

26,720

20,404

242

TIpley

28,851

10.694

167

Fush

10.915

10.241

220

St. Joaeph

161.067

103,304

58.603 
Teble 7 cont.

county

1940

1920

Not Chonge

\begin{tabular}{|c|c|c|c|}
\hline$s \cot t$ & 8,071 & 7,424 & 647 \\
\hline Shelby & 25,924 & 25,932 & 58 \\
\hline Spencer & 16,209 & 18,400 & 2,191 \\
\hline stsrke & 12,147 & 10,278 & 1,869 \\
\hline Stouben & 13,709 & 13,360 & 349 \\
\hline Sullivan & 26,783 & 31,630 & 4,847 \\
\hline Switzerland & 8,164 & 0,311 & 1,147 \\
\hline TIppecanoe & 51,218 & 42,813 & 8,405 \\
\hline Tipton & 15,100 & 16,152 & 1,046 \\
\hline Union & 0,013 & 0,021 & 8 \\
\hline Venderburgh & 130,700 & 92,293 & 38,416 \\
\hline Vermillion & 21,763 & 27,625 & 5,852 \\
\hline Viso & 99,467 & 100,212 & 745 \\
\hline Wabash & 26,568 & 27,231 & 663 \\
\hline Werren & 9.033 & 9,699 & B68 \\
\hline Warrick & 19,421 & 19.862 & $44 ?$ \\
\hline vasulneton & 17,010 & 13,645 & 365 \\
\hline Wayne & 59,059 & 48,136 & 10,823 \\
\hline We11s & 18,104 & 20,508 & 1,405 \\
\hline Whito & 17,114 & 17,351 & 237 \\
\hline Whitioy & 10,934 & 15,600 & 1,274 \\
\hline Totol & $3,41 c, 152$ & $2,930,390$ & \\
\hline
\end{tabular}


APPEMDIX 5. 


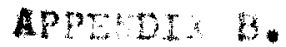

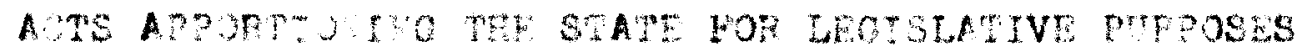 \\ An sot for the Apportionwont of senetors ond Representatives}

wthin this state. Approved Jenuary 2, 1821

ISRTCT

Rox, Devies, Wartin

Sulilvan, Vieo, Croan, Jwen

Jefferson, Jentings

Clark, Flogd

Mashineton

Jackson, Scott, Bartholomew

Orange, Lawronco, Monroo

Marriaon, crawford

Posey, Vanderbureh, loone and Anderson

zownships in Terrick

spencer, Perrg, Dubola, Luce Momahlp in

warriok

clodion, Plke

Wayno. Randolph

Fayotto, Trion

Prankiln

Dearborn

Sw1tzorland, Repley

$$
\text { MEPREN BATIVS }
$$

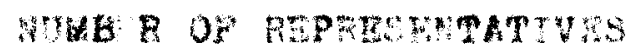

Rnox

Davioe, Mertin

V180

Sulliven

Grean, Owen, Morean

Jerforson

Janntnge

Cierk

loga

Washineton

Jackeon

soot

orange

Lavrence

Korroe

Marmison

rawford

Posey

Gloson

Pike

Vanderburgh, Soone and Anderson

Townghlp in warrlok

\section{WUPEF OF SEALORE}

1

1

1

1

1

1

1

1

1

1

1

1

1

1

1 
Acts of 1821 cont.

98

TOPRESENATVES

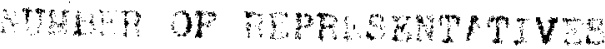

Spencer, Perry, Rubols, Luce fownship in

Fotriok

Fiandolph

viayne

Fayetto

Union

Pranklin

Switzerland

II ploy

Dasrborn

Eartholomew 
An Act for the tpport onment of Sentorg and Fepresentat ves

to tho donors 1 Assombly with tha stote - gproved denury

$15,1820$.

Draters

WHEF OF SWATSE

posey, Venderburgh, harrick

1

epencer, Porry, Crawford.

Ibson, Plke, Dubols

1

nox, Lavles, hartit:

VIro, sullivan, Ley

sonroe, wer, Green

Parko, mutrom, Montgomery, countain,

Vermfilion, and 11 country north of

321 three last mentioned counties to

the ndene boundery

Herrison

srange, Lawronce

waington

clerk, Floyd

Jeckson, 3cott, Bertholomew and coutry

weat of Eartholomew to the line of

wonroe

Jefrerson, Jenninge

swltzerland, Rlpley

Deerborn

Fronkin-

Feyette, union

wayne

Rusb, fienry, Randolph, H2on

Decetur, Sheloy, Johnson, worges

Marl on. Hendricks, Hemilton, edis on, and

all country north of the seld throe last named

countios to the webesh Fiver

BHPRESENTEVTES

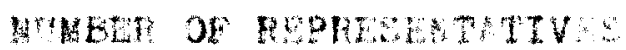

Weyne

Dearborn

Clerk

1

1

1

1

1

Wounington 3

Ferision 3

Frenkin 2

Swltzerland 2

Jefrerson

Orange 2

nnox 2

Fayotto 1

inion 1

Sne to elected alternetely sron Fyotte

and unton Countles, befinntine with Fotto

county

Rush

Decatur 
Act of 1826 cont.

Alploy

THPFEE TATYVES

Jentines

serion

Jackson

seott

Floyd

Crawford

Lawrence

Sonroe

Gibson

posey

Sullivan

vico

Vanderburgh, Warrick

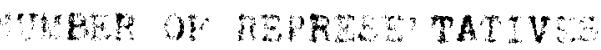

spenoer, Porry

Plike, Dubols

Devies, wertin

oreen, owen

Putnan, clog

perte, Verwiliton

wonteomery, Fountein, and 11 thecountry

north of sald last namod countise and

north of Veratilion to the Indian lounders

Worken, Fendrioks, and all country north

to Viabash River

Sheloy, Johns on

Fendolph, Allon and 11 the country ly!ng

north of kedison and ilton to tho mebesh

Biver not attached to other districts

1

1

1

1

1

1

1

2

1

1

1

1

1

1

1

1

1

1

1

cortholomew and everythin rost to sonroe

County

1

$\frac{1}{2}$

1

2 
An Aot for the Apportionment of Sonators and hepreacetatives

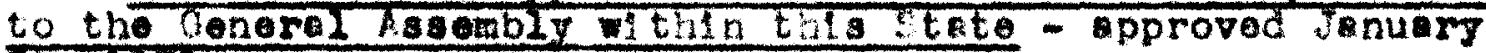
3. IESI

$$
\text { GNATRS }
$$

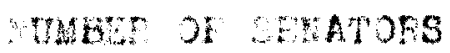

Posey, Vunderburgh, arrek

1

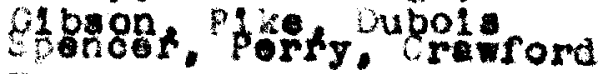

Rnox, Devies, artin

Gerrison

Fieshlngtor:

sonroo, froen, Owen

Vorgan, Fondricka, Eoono

TIppecinoo, Carroil, Ca

sontromery, clinton

Jrenge. Lawrence

Verwlilion, Herran

Rendolph, Felswere, Allan, Elkhart,

St. Joseph

isanry, Mulson, hencock

varton. Memliton and 11 combry north of

1

1

1

1

1

1

iamition to the oreat iflemi Foarvation

Fountain

Johnson, lartholom

Jonnlnes, Jackson, Scott

Clark, Fiord

jerferson

Swltzerland, Ripley

Sholby, Decets:

Doerborn

Frankl1n

Eayotite, Uni on

ineyna

Haln

Putnom

Sul11van, V160, trey

Parke

1

1

1

1

\section{REPHESGMATIVS}

พxy

Deerborn

Wabluston

oranfo

Lawrenoe

Teiforion

Push

terrison

Putnem

Founta:n

Tippecanoe

1
1
1
1
1
1
1
1
1
1
1
1
1
1
1
1

FrenkLin

Payette

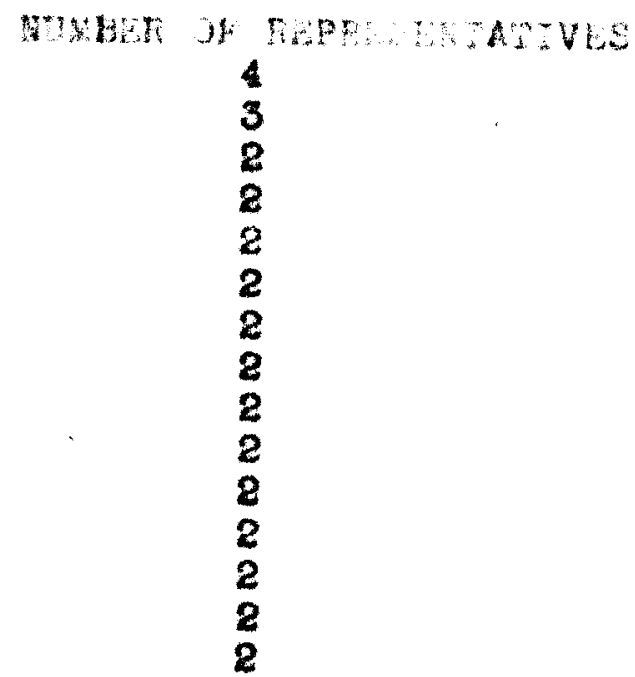

Union

Clerk 
Acts of 1031 cont.

PEP AOATHE

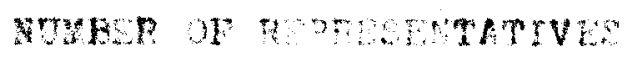

Posey

31 bson

1

crawrord

1

Creone

1

owen

1

onros

sul11ven

Werren

sultzerland

1

\% 1 ploy

Jernings

1

veott

Floyd

cley

Joknson

rorgen

lendrl cks

sholby

Decetur

tenry

yerion

Fandolph

Bartholomew

VIro

Jackson

Vandorburgh, werrlok

Porry, spercer

P1ke, Dubol.

Rnox.

Devioa, Martin

One to be elected alternately beglnning

wt th rax

Honteorery, clinton

Carro11, Cass

llamilton, boone, and 12 country iorth of

oreat Ment reservetion

Hedison, Uneock

A18n, Elkhart, St. Joseph

Vermi21 on

Perke

Tne alternately from two precodine

countles beglnning uth Vormllilor

Dolawaro and $n 11$ territory attached

clark, floyd

Ona elected alternately from two procedinf

counties beginning wth Floyo 
An lot for the fport on ent of Senstors and Represantetives

to the Coners 1 Asembly ithln this state - opproved isnuary 13,1836 .

thet for the purpose of olect lne Sanctors to the conerel Assombly of this state for onsulng five years the tate shall be and is divided into the folloving diatricts, on of wh dh 13 entitied one Senator.

inox, Davies, wart!n

Lawrence

creen, Owen

V1po, sul118an, Clay

Putnam

Parke

Hountain

Vormilition, warren, and all south of

jeapor 11 ne betwoen Townahtp 24-25 1

Tippecanoe

olinton, corroll

tont ronery

Serrion

Perry, Crawiord, spencer

Ferrick, Vanderbureh, Posey

Glogon, Pike, Dubols

oranga

Yonroe

tiondrloks

Shelby

tartion

Mnacock, had son

hiamliton, Boone

Cesa, Haml, Fulton

Allon, Molls, Adems

Wabab. Joy, hatington, crant

Nikhert, Locrange, stouben, Doknlo, Noblo 1

Dolaware, Randolon

ienry

Fayotte, Union

st. Joseph, Warsill, Kosclusko, tarke

Laporte, Porter, Newtor, White, Pulakk, and

-11 of Jesper North of line botween Townsis ps

$24-25$

Fuah

Frankiln

Doer orn

Dedetur

Switzorland 
Not of 1836 cont.

Hipley

1

Bartholomew, Jennlage

Clerk

loyd

Jorterson

Jeokeon, Scott

hasulneton

Wagne Gorovided if Jasper becomes organt aed

seld territory shell be attechod to county of Jesper.)

1

1

2

1

1

2

8

MOUER OF REPRESENTATIVES

Denrborn, Nayne

Rush

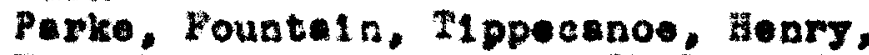

4 from ach county 3

Fayette, Unton, Mari on, Bheiby, Lerrtson, Lawresoe, Prenklin, Joffereon, washlngton, Clerk, Vermililon, Bertholome:

Irom each county

of line of clay.

of Iine 84-86, clinton, Carroll, konroo.

Johns on, vorgen, izenari oke, Mancook,

Kadison, Hemilton, boone, Al2en, Elishart, Delavere,

Rendolph, 3t. Joseph, Laporto, Jecatur, kipley.

twitzerland, Orange, Poney, Vanderburkh.

warriok, alboon, Cass, Hoyd, Jeokeon, Eoott,

Jonninga

In 1036 Knox, Devies, Hertin, locted

In 1857 Rnox olected

Devios, Martia elected

In 1838 Xnox, Devles, Kart in elected

In 1838 gnox lected

Darles, Yart in elected

In 1840 Knox, Devles, Mertin

Sulliven, V1go locted

in 1840 bhen Vlgo elected

sull1 van

Putnem, thontgomery

additional alternately with putnaw.

In 2836 crawforö, Perry, Spenoer

Plke and Dubale

In 1937 Perry, Spencer, Plke,

bubola and Cremford

In 2830 Perry, Spencer, Cromford

Plke and Dubots

In 1830 Porry, Epencer

P1ke, Dubols, Crawford

In 1840 Crawford, Porry, Spencer

Plike and Dubol:

guntlagton, Wolla, Joy, Adem

Orant, Webesh

Legrange, Stouben, Doka10, Moblo

I from onoh county

1 oeob

2 and

Gouch

2 each

2 and

1 jolntiy

1 bech

2 esch unt1 1040

3 and

1

2 oech ond 1

1 eech

1 jolntiy

1 eech

I jointiy

1 onoh

1 jolntis

1 Jointiy

1 eoch

1 onoh

1 jolntiy

1 jolntiy

1 jolntiy

I jolntiy 
Let of 1650 oont.

Neraha11, Kotelueko, Sterke

Porter, sewton

White, Jeeper, ruleakl

Hem1, fult on

Jerfervon, (in $1836,1837,1849$ )

teahingzon (in 1838)

1 Jolntiy

1 jolntiy

1 Jointiy

1 Jolntiy

1 adaltional

1 adel tonel

1 daltional 
An Act for the Apport lonment of Senetors ond Represont 107

to the oonerel Assemblr utibla thla Stete - opproved January 20. 1841.

SSNAFORS

Putnam

Montgomery

Parizo

Anox

Lawrence

Vermil 211 on

clinton, Carroll

Vigo, ciey, Suliliven

Earrion

Orenpe, Crewrord

Devi es, Martin

konroe, Erown

Perry, Sponser, Werrick

Owen, oreen

Vanderburph, Posey

olbson. Plke; Dubola

Fiendrioka,

She 1 by

turt on

Madison, Hanoock

Enat1 ton, hoone

Henry

Fayette, Unt on

Prank11

Doarsorn

Ripley

Sitzeriend

Jennluge and Bartholonew

Jiark

Floja

Jertereon

Juoks on, Boott

Fabington

vountain

TI ppecenoe

Orant, Deleware

Johne on

Morcen

Doostur

Ruab

Cese, MLami, Wobeah

St. Joneph, Warshell, Fulton

Elkhart, Eosolukko, hit ty

Luorenge, Stouben, Noble, DoKelo

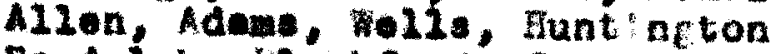

Rundolph, dickfore, Jay

InPorte, Lake, Porter

varron, White; Pulaekt, Jaeper, Lenton, starkel

Wayae
NUTHEF OF SENATORS

$1^{1}$

1

1

1

1

2

1

1

1

1

2

1

1

1

1

1

1

1

1

1

1

1

1

1

1

1

1

1

1

2

1

1

1

1

1

1

1

2

2

2

1

1 
108

not of 2842 nont.

Parke, Fuah, Vteo, Clark, Garrton,

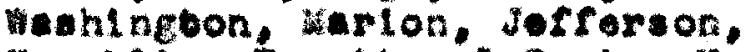

Frenicila. Fayette. Laporte. Menry 8 eech

weyro, Deemoorn

3 each

Orange, sholyg, Warrick, Venderbureh,

Knox, sul21ven, Ola, Varmi111 on, Ferren, 01

Clinton, Cerroll, Worent, Johneon, Jenninge.

Mogd, Soott, Jaokwon, stitzarlend, Ripley.

Deoatur, Cass, Elikhert, st. Joseph, H11en.

"zenarloke, Deimware, Grent, Poses; q1baon.

Spencer, Perry, Rendolph, unton, Crene.

owen, Pike, Dubote, Crawrord

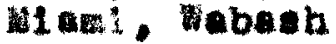

Funtlington, Blackrora, Wel1.

milt loy, Koselusko

Marahe11, Fulton, Starke

White, Pulaekl, Jesper, Eenton

Noble. Lacrenge

Steuben, Deteib

Aanes, Jay

ionter. Lee

Hontgomery end Pulnon

pountaln begining wont gomery

I1 ppeoenos

Fountein bed 1 extre in 2048 and 1846

Tippecanoe bed 1 extra in 1843 and 1844

wami 1 ton and toone

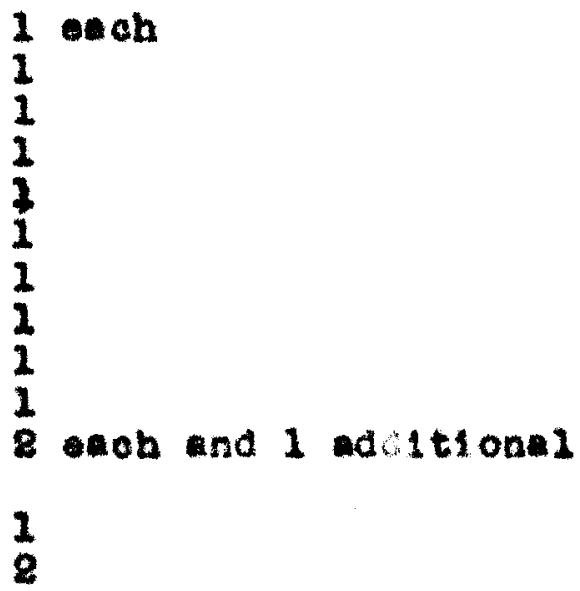

atternetlag beglanto with Hantiton

tounty.

Union bad $i$ extra 1 a 1841 and 1805

Rendolph had 1 extme in 1645

Fush bed 1 extre in 1842

Jerferson had 1 extre in 1842, 1843, 1844, 1845

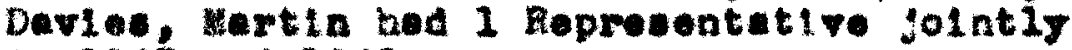

In 1043 and 2646

Devies, wartin bad 1 fepresentative eech

1841. 1042, and 1044

tertholomew, Lawrence

tonroe, Erown

Lewrenoe, Loaroe, Srown

beglaning it th Laweroe.

Ladion, Gencook

alcomately beglaning w1 th lancock.

1 each and 1 additional

$v 1$ to had 1 additioni in $1648,1643,1844$.

sul21van, had 1 daltionel in 1841 and 1845.

1 each

1 jointiy

1 atcrostely

1 each and 1 edit 1 tonm 1 


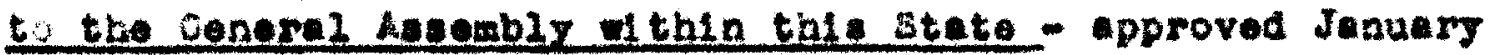

16.1846.

SEATORE

DITEER OF senATORS

Stauben, Dekalo, Noblo

Ekhert, Luars ne०

Rosoluoko, bitiog. Muntington

Mllon, Woils, hdara

2

Jay, Eleokford, Rendolph.

kegroe

Menry

Delawne, arant

Nebarh, Manl

Richardvizlo cas: Pulesint

Pulton, Varabali, Stark, St. Josoph

Laporte, Porter, Lake i

Feyette, Jnion 1

pronkiln

Dearborn

Ripley 1

Muah

Deostur

Madison, Eancook

T1ption, Boone, Sinm1 2 ton 2

carroli, Clinton 1

rlppeoanoe 1

Pountaln

Hontgowery

Parke, Vermil110n 1

Putoan 1

liendriok ok

Mertion 1

Shelby 1

Jobna on 1

tergan 1

CIFy, VIgo, Bullivan 1

Oven, Greene 1

Bertbolonew, Jenninga 1

wonroe, Exown 1

Oblo, swtterlend 1

Jetrerson 1

olerk

Jeckson, seott 1

Lewrence

Washington

Darrison

Ployd

Orange, crewtord i

Xnox

Dev1 oe, Martin

Plke, Glbson, Dubols

Poesy, Vandersurgh is

Varrick, Spencer, Perry 2

warron, White, Benton, Jasper 1 
Act of 2846 eont.

HEPRESETATTVES

SULEST OF REPRESETTATVES

W yne

In 1940, 1847, 1840 had isepresentetives

Tlpoecenoe

In 1847 and 1849 hed 3 representetives

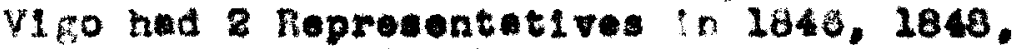

1849 nd had 3 leprosentetivas in 1847 and 1860

perke, Putnaw, Sonteomery, Rush, Posey,

Frankitn. Janry, Wastington, Clark.

Sulliven hod 2 hepresentetive in 1647 and

1050end hed 2 Reprosentatives in 3946 ,

$1840,1849$.

Kosolusko, st. Joueph, Werron, Orent,

Delaware, tadson, Vorallil or, Hendrioks,

Hancock, Unlon, Deortur, Johneon, Scott,

Loyd, Lavrenoe, Knox, Dubals, Pike, 01beon,

Vanderburgh, werrlok, Spencer, Parry.

arrison hed

Cess and "Il oharavi210

hed 2 Representatives in 1046.

Pountain

Clinton, Sipton

2 Representatives in 1840 and 1860

Laporte,

Allon

2 Sopresentativen in 1847

tikhart

E Reprosentutives in 18.43 nd 1840

Lacrange, Nobl

carroll

In 1846 end 1850

Randolph

Mart on

2 Fepreabntetives in 1847 end 1849

3 Representetives in $1040,1846,1880$

Burtholonew

2 pepresentative: in $1848,1640,1850$

Jeffereon

3 Representetives in 184 , 1849

Aand Iton

coone

C Hepreantetiveo in 1840,104

2 Hepresentetives in 2847,1850

shelby

Fajotto

2 Hopreaentetives in 1847 and 2850

Dearborn

8 keproantetives in 2848

Monroe and Brown bad 1 each in 1846, 1840 , 1050. Fed I Fepresentetive Jolntiz in 1647, 1249.

Devtes, Hertin hed 1 each in 1847, nd 1849.

Gind 1 folntly in 1846, 1840, 1860.

oranged crawford hod teqeh fn 1847, 1040, 1860.
3

2

2 onch
1 exch

1 eech but

1

1 and had

2

1 and had

1 und had

1 and 1 each

1

1 and

2 snd hed

1 and hed

2 ond had

1 and had

1 and had

1

1 and hed

2 and had 
Act of 1846 cont.

REPRESENTATIVES

Ohlo, Swltzorland had 2 jointly in 1847

and 1849. Fad 1 in 1846, 184e, 1850.

Stouben and Doxalb

Shitiey and Huntington

Wo21s and Adems

Mem1 and wabesh hod 1 each in 1846, 1948 , 1850 and had 1 jolntly in 1847 and 1849 .

Marshall, Fulton, sterk, jolntiy oloot 1

Representative.

Porter and Lake

Pulaskl, Jeaper, Whlto, benton

Jey, Blackford

1 jolntiy

1 jointiy

1 jointiy 
An Act for the Apportionment of Senators and Fepresentatives to the Generel Assembly within thls State - spproved February, 13,1851 .

SHARORS NUMEER OF SENAPOES

Etouben, DeKalb

slikhert, Lagrange

roble, Koseluako, whitley

Huntington, welle

Al2en, Adams

Randolph, Jay

Delaware, Bleckford, arant

Hani, Minbara

Casa, Pulask1, Howard

St. Joueph, Fult on, Marahal1, Stark

Laporte, Lake, Portor

Warren, Benton, Jasper, White

Carroli, Clinton

Hamliton, Tipton, Eoone

Tlppecanoe

Founta in

Parke, Vemil11 on

Vigo, Sullivan, Clay

Putnam

Mont gonery

Hendriok

Horgan

Narion

Hadison, Hencock

Orange, Cravford

Martin, Knox, Davi

Merrioon

Ploya

Warrick, Speneer, Perry

Posey. Vanderburgh

P1ke, Mlbaon, Dubola

Ienry

Weyne

Union, Payette

Rush

Pranki1n

Shelby

Johns on

Owen, Greene

Nonroe, Erown

bartholowew, Jenninge

Decatur

Dearborn

ILIOY

Switzeriand, onto

Jefrereon

Jeckson, soott

Clark

Washington 
Lawrence

Knox to be attached to Devies and

Martin, Huntington and Wiella to elect In 1851 .

PEPRESENPATIVES

WMBER OF REPFESENATIVES

\section{Wayne}

Marion, Frank11n, Dearborn,

Sullivan, end Jefferson

Woble, Whitloy, Wabas, Grant, Want,

Kosclusko, LaGrange, st. Joseph, Fulton,

Casa, Laporte, Porter, Lake, Carroll.

Warren, Olinton, Union, Fayetto, Eancock,

Parke. Fountain, Vermililon, Owen, Morgan,

Johnson, Sholby, Deotur, Ripley, Jonnings.

Bartholome, Monroe, Brown, Groene, Knox,

Davies, Martin, Gibson, Fike, Duboí,

Lawrence, Jackson, Scott, lierrison,

Was ington, Orange, Cranford, Perry,

Speneer, Merriok, Vanderburgh, slihert,

Gendrloke, Allen, Adams, Jey, Blackford,

Delamare, Randolph, Renry, Cíark, Floya.

Hont gomery. Banilton

$160 \mathrm{ch}$

Swltzerland and onio

2
2
1
1
1
1
1

Stouben and DeKalb

Huntinfton and We11s

Marsholl and Starke

掣it te and Eenton

Pulaski and Jaspor

Howard and pipton

2

Yadson, boone, Posey, Clay had 2 Representatives in 1351 and 1854. Otherwise they had 1 Representetive.

Rush, Putnem. TIppecenoe had 1 Representative in 1851 and 1854. Othemise they had 2 Ropreasent $t$ ives.

VIgo had 2 Ropresentatives in 1851 and 1854. Otherwise had 3. Weahington hed 1 additional in 1854

Ford had 1 aditionel Representative in 1852 and 1853. Clark bed 1 additional Fepresentative in 1851 and 1853. Montgonery had 2 daltional Representative in 1851,4853 , and 1855. Henry had 1 additional Representative in 1852 and 1854 . 
An ct for the Apport ionmert of genetors and $Q P=$

resentet vea to the ceneral as moly withir this totoe

for next 4 years. foproved ixeh $8,185 \%$

Thet for the purpose of elochlog sentors to the

Goneral hasombly of seld state, the scme sholl be, and

is horeby alvided into fifty districts to wit.

\section{SDOPF}

Posey, Vanderbureh

Werrlck, sponcer, serry

crewrord, Jrene

lioyd

Veshington, Harrison 1

clerk, seott 1

Jefferson

Dhlo, Swltrerlond I

los wixe, Dubols 1

Enox, lavtos 1

Hertin, Lawrence

Nonroo, brown

Gron, Owen 1

V180, sulliven

clat, Putnes

Perke, Vermilion 1

Johnsor, Morgen

Jenning, Jeckaon

intiolomew 1

iliploy 2

Docatur 1

Dearborn 1

Frenk1in in is

Feyette, inton

Pusin

Wayno 1

Ienry 1

Shelby, Cnoock 1

sedison, orent

Mer!on 1

Hendrloks, boone 1

vont pome ry 1

fountein

Tlppeceros 1

worren, centon, whlte 1

clintor, Carroli

as: Howerd, viask: 1

iam1iton, Tipton 1

Randolph 1

veleware, blackford 1

Adoms, Lel1s, Jay 1

whitley, Munt: neton I 
Act of 1957 cont.

Bxatons

wom

A110n

kaben, Kusclusko

Sob1e, Jeks 1b, Stauber.

Lacrance, Lithert

Ct. Josep. Wersholl

Le eorte, istork

Lake, Porter, is per

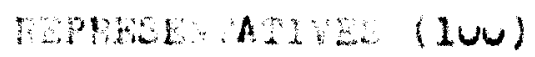

Posey

Venderburah

Fosez. Vanderburih (jolnt2y)

werrlok

spencer

Porry

Grewrord

srenga

Floyd

herris on

wasblupton

far ison and hasulnton (joltity)

cork

scott

jefferson

On:o and Switzerlana

abson

Plke

subola

innox

Luvies

liant $1 \mathrm{n}$

Lavrence

ronroe

Erown

"utnem

parke

Vermi111 $n$

Jom 3 on

worgan

Jonson end toren (Jolntiy)

Jenrines

Jacksor

bart holomew

Ipley

Decetur

verborn

Frankl1n

rayetto, Urion

mash

vieyne

Ionry

she lby

llancock

Sholby and Hancock (Jolntiy)

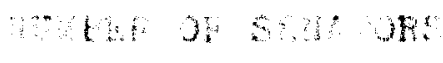

1

1

1

1

1

1

1

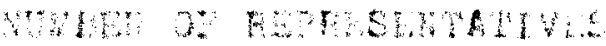

1

1

1

1

1

1

1

1

1

2

1

1

1

1

2

1

1

1

1

1

1

1

1

1

1

2

1

1

1

1

1

1

1

1

1

1

2

1

1

1

3

1

1

$\frac{1}{1}$ 
Act of 1857 cont.

THESERTIVES

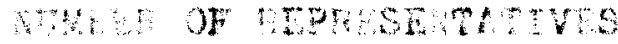

4sact 30 n

terton

tonars oks

soone

Hendrlcka nd toone (jolntiy)

vont romery

Founte in

Ippocanoe

timrron

得 eraha 11, starke

Leforte

Lake

forter

benton, whl te

cinton

Carroll

Cas

Jospor, rulaskt

Uanlitor, ipton

Grant

Mowerd

Fandolph

Delawero

Adems

We11s, thackford

Jay

wibl toy, huntinfton

1

:

Hilton

Alien

Wabsen

isosclusko

habash and Kosclusko (folntly)

lioble

Dekalb

stouben

Lacrenge

Likhert

LeCrenge ond ikhert (Jolntly)

st. Joseph

1

1

I

1

1

1

1

1

1

1

1

1

1

1

1

1

1

1 
An Act for the pport onmest of enators end popresentetivea

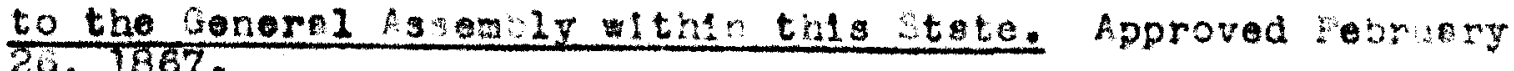
20.1867.

soction 7 . That the conergl Aso mig sholl const st of

fify Sentors and one hundred Fepresentatives.

SEMAPUS

Posey and albson

Vandorbureth

Farrek, Spencer

Knox, Levios

Plke, bubols, irtin

ory, crawford, orange

Lawrence, unonroe

trown, Jackso:

Was lneton, wrison

loyd, lark

scott, Jonntage

Jefrerson

Swizorland, iplay

010 , Deer orn

Frankiln

Feyetto, Unt on

Rush, Eocatur

Shelby, Eertholomew

Johnson, Worpen

creene, Jwa

-10y, Sullivan

Vigo

Butnam, Fondrloks

Parko, Vormi111 on

tont eomery

Founte1n. Warron

TIppoonoo

clinton, Boone

iterion

lencock, zenry

Wagne

Fandolph-

Colaware, Hed:son

ilamilon, ripton

hovend, Carroll

Coss, Fulton

Pulaskl, white, tenton, Jasper, woton

Lake, Porter

Laporte, ts tarke

st. Jooeph, 被sheil

sixhert

koscluako, hitiey

vabesh, rami

arent, in kford, Jap

Huritigton, Wolls

Alion

P110n, Adams

lioble, Lacrenge

Kalb, stouben

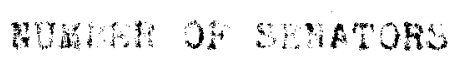

1

1

1

1

1

1

1

1

1

1

1

1

1

1

1

1

1

1

1

1

1

1

1

1

1

1

1

1

2

1

1

1

1

1

1

1

1

1

1

1

1

1

1

1 
ict of 1607 cont.

Fopresentatives

Hamber of tepresentet ves

Posey

Vanderburgh

verrok

Olbson

slike

inox

Davies

Hartin, Jubola

Spencer

Perry

cravford

orengo

Wabinfton

Narrian

kloyd

clark

Jerforion

lerk, Scott, Jerferaon

Jefrereon, Riplay

sultzorland, onlo

Donarborn

filpley

Frankiln

Tush

Decotur

Fuah, Docatur

Jonndings

Bertholomow

Eartholonew, whelby

Brown, Jakson

Monroe

Lawronce

Orone

Sull1ven

$01 \% \mathrm{y}$

Vico

Owen

Putn m

Rendrloks

rutnem and itendricks

isorgen

Johnson

worgan, Johrson

Marton

hinoock

thelby

Menry

sagette, unt on

1

2

1

1

1

1

1

1

1

1

1

1

1

1

1

1

1

1

1

1

1

1

1

1

1

1

1

1

1

1

1

1

1

2

1

1

1

findolph

velevare

Ienry and hadion

Vindition 


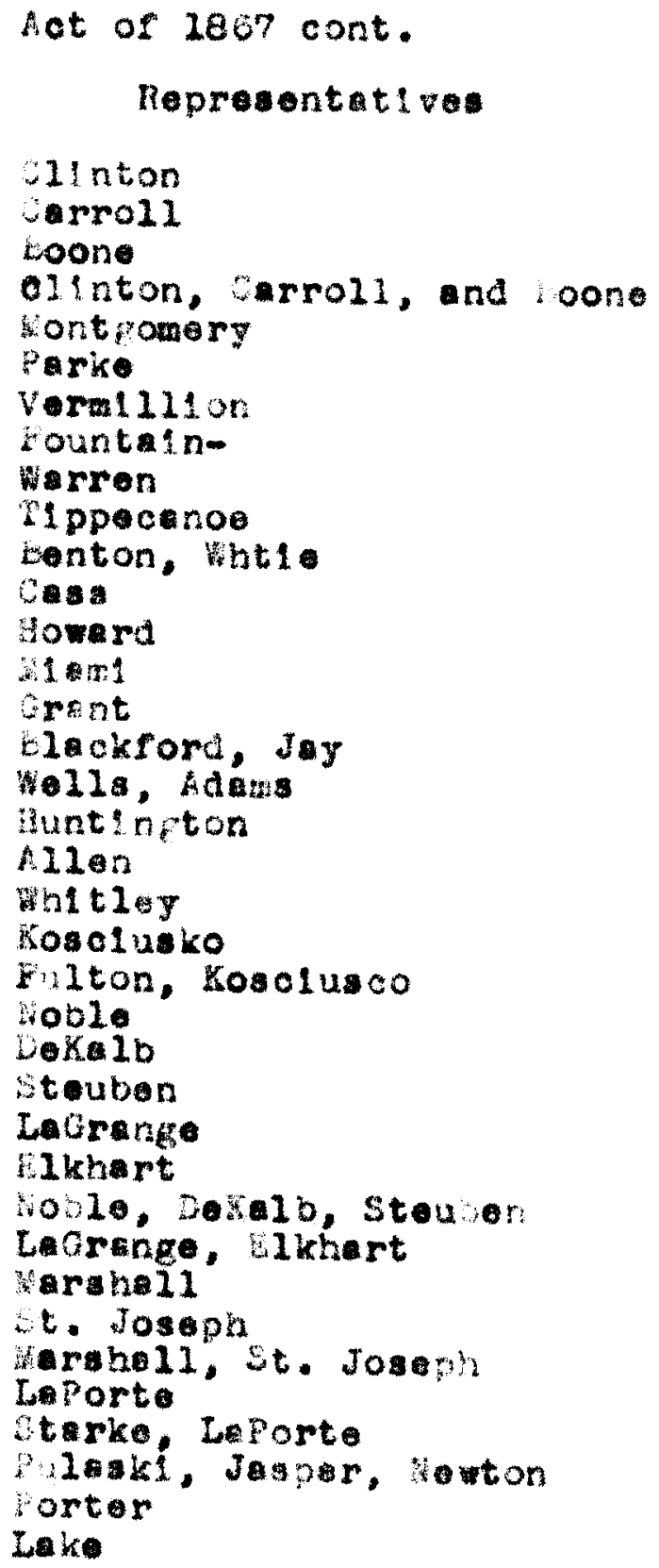


An Act to fix the number of senators and fopresentatives to the Conerel Assembly within the state ond declaring an emerency, tecame law by lapse of time Lecomber 27, 1872.

Posey, Gibs on

Vanderb reh

Warrick, P̈lke

$\frac{1}{1}$

Spencer, perry

Sullivan, Inox

Davies, Groene

intin, Orence, Dubols

Crawford, llarrison

Floyd, lark

Washineton, Jackson

Lawrence, Monroo

Erown, Eartholomew

Scott, Jennings, Decetur

Jefferson

Switzerland, Ohto, and Ripley

Decotur, Rush

$\forall 1 \leqslant 0$

Owen, lay

Shelby, Johrs on

Putnam, fiendrlcks

Perke, Vermililon

Eountaln, Warren

Tlppecanoo

Lenton, Nowton, Jasper and wht te

Laporte

St. Joseph, Stark

Nershell, Fulton, Pulaskl

rosclusko, whitioy

Elkhert

froble, Lagrange

Steuben, DeKaIb

Allen

Allon, Adems, Wells

Huntineton, Wabesh

Gront, blackford, Jay

Hiaml, Howard

Cass, Carroll

aemilton, T1p on

boore, Cilinton

Madis $n$, Dolawero

Randolph

Viagne

Henry, Lencock

Fayete, unton, frush

Wer on

Dearborn, Frenklin

Hont comery

Lake, Porter \\ NUWEER OF SWATORS}

1

1

1

1

1

1

1

1 
let of 1972 cont.

Posey

ibson

Vanderbureh

torrlck

pke

wernor

?orry

suldiven

तno.

Dev:ea

Groeno

hartin. jubola

rowrord, urange

Uerrison

Mord

clork

nasington

Jeckson

Lewrence

Honroe

Erown, bertholomen

Jenntugs

St. Joseph

rosclueko, iulton

Fulson, Pulakki, Starke

koaclusko

initioy

Vikhert

roblo

LaGrange

steuno

Defalo

filien

idems, fie11s

hunt infton, wobash

Grint

wam!

howero

Casa

C.1.011

Howliton

lievilton, Tipton

scott, Jenntngs

Jefferson

II pley, Decetur, and hust

is $1010 \mathrm{y}$

swtzerlsnd, ohlc

secatur

Tush

VIgo

oven

clay

vorgan

1

$\frac{1}{2}$

1

1

1

1

1

1

1

$\frac{1}{2}$

1

1

$\frac{1}{2}$

2

2

1

2

1

1

$\frac{1}{3}$

1

1

2

Johnson 
Act of 1872 cont.

DEPRESENTATTVS

WUABEF OF FEPRESENTATIVES

Jokna on

Putnam, Hendricks

Parko

Vermillion

Parke, ontromery

Varren

Fountain

Iippocanoe

1

Benton, Newton

Jesper, Whit te

Porter

lilami

tuntington

clinton

Hontomery

Eoone

Hadis on

Dolawaro

Delaware, Jay

Randolph

Wayno

Henry

Hancock

Henry, Madison

Fayette, Un:on

verion

Shelby

sher on, sheloy

Dearborn

Franklin

Noble, Elkhart

Marshall

Ylami, Howard

Lake

Laporte

Eowerd

Wabash 
An Act to fla the number of semors and Representatives to the Ceneral Assombly of Indlana and to epportion the seme. Approved tirch $8,1879$.

SENATORS

NUEEP OF SWATOKS

Posey, Glbor

Venderbureh

Werrick, Plke

Spencer, Pery

Crawford, Harrison, and orango

Lubols, Hertin, and Lawrence

Clark, scott

Jefferson

Decatur, shelby

Floyd, Weshington

Franklin, Riploy

Dearborn, Onto, and Switzerland

Jeckson, Jennings

Erown, Wonroe, and Bartholomew

Creene, Davios

Knox, Sulliven

Vigo

Clay, Owen

Parke, Vermi111on

Weyne

Randolph, Dolawero

Henry, Nelaware, and Randolph

crant, Wadison

boone, CI1nton

wont omery

fountein, Werren

Tippecenoe

Lenton, Newton, Jasper

Lake, Porter

Laporte

st. Joseph, Starke

lerahe11, Fulton

Cass

Losclusko, Wabash

Eilkhart

LaGrenge, Noble

Stoubon, DeKaIb

Allen

Allon, Whitloy

Huntineton, Nol13

Adams, Jay, and Elackford

carroil, White, and Pulask1

Merion

Werton, Hencock, and shelby

liendricks, Rutnam

Horgen, Johns on

TIpton, Ham1iton

Rush, Eayette, inion

1

1

$\frac{1}{3}$

1

1

$\frac{1}{1}$

1

1

Howard, H1 $1 \mathrm{mi}$ 
Aet of $18^{\circ \%} \mathrm{~g}$ cont.

TEPRE LUATT KS

NOE OF FPPTEE TATTES

Posey

Gibson

vanderburgh

1

Warrick

Elke, Dubols

Sponcer

Perry

Crawford, orange

carrison

washington

Dubots, tartin

Clark

Clark, 3cott, and rloyd

Flord

Jefferson

iploy

switzerland and Ohlo

iertion

Jemilton

it ndricks

itorgen

Johrison

Lheloy

iancock

Lertholomew

tradison

Ked1son, Hancock, and henry

Werlon, Shelby, and bartholomew

1

2

1

1

1

1

1

1

1

1

1

1

1

1

1

5

1

1

1

1

1

Lecatur

Rush

leyette, Un:on

lienry

Lelaware

Crsit.

Dearborn

ronklin

Jackson

Jennings

Soneos, Brown

Lawrence

Davies

Greene

cinton

xnox

Sullivan

Fnox, Sulliven, and Greeno

Viro

clay

Parko

Vermilion

Wayne

Fandolph

Franklin, Dearborn, and Ripley

1

2

1

1

1

1

1

1

1

1

I

1

1 
Act of 1879 cont.

REPRESENTATIVES

NUMLEF OF HEPR ESAMLATVES

Kosclusko

Warran, Eenton

hotele

t11en

teuben

wel1s, Elackford

Aders, Jay

Llkart, Noble, and LeKalb

1

1

3

Kosclusko, liabash

coward

II $1 \mathrm{ml}$

coone

clay, Putnam, and hendricks

1

lontromery

Putnan

bourtein

benton, inite

ip ocenoe

tewton, Jasper

Owen

Lake

Porter

Laporte

St. Joseph, Starke

1

1

1

1

1

1

1

1

1

1

1

1

2

1

1

st. Joseph

uarsha 11

Casa

Wikhart

LeGrenge

Doralb

Whit ley

iunt ingt on

Joy, Adams, Hells

arpoll

ispton 
An Act to fix the number of Senetors and Representatives to the General Assombly of indian to apportion the ssme amone. the several countios of the state and to repeal all laws in conflict therewth. Approved Merch 0, 1885.

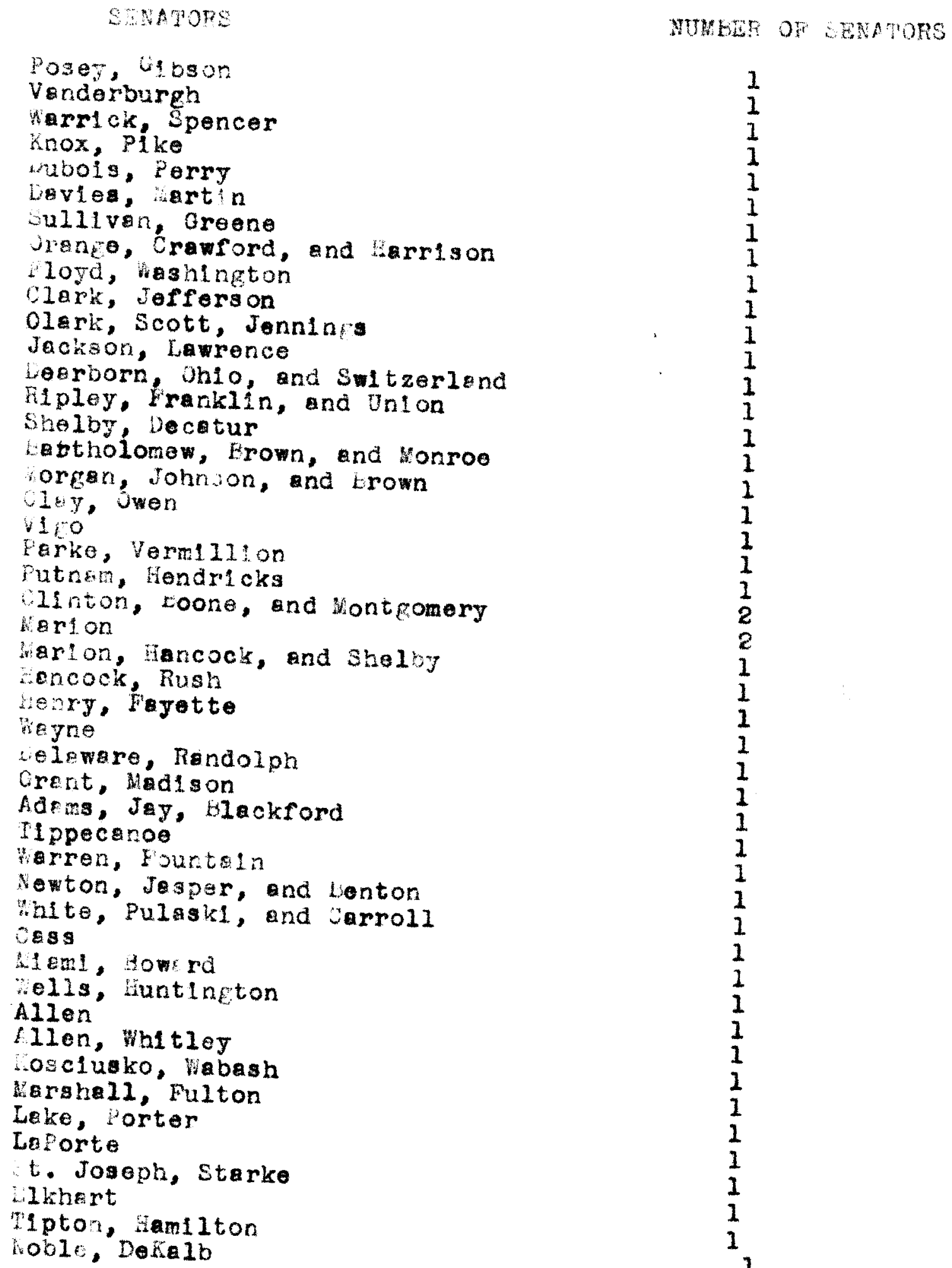


Act of 1898 cont.

R PFESETATIVES

NUEE OF FPRESR A TVES

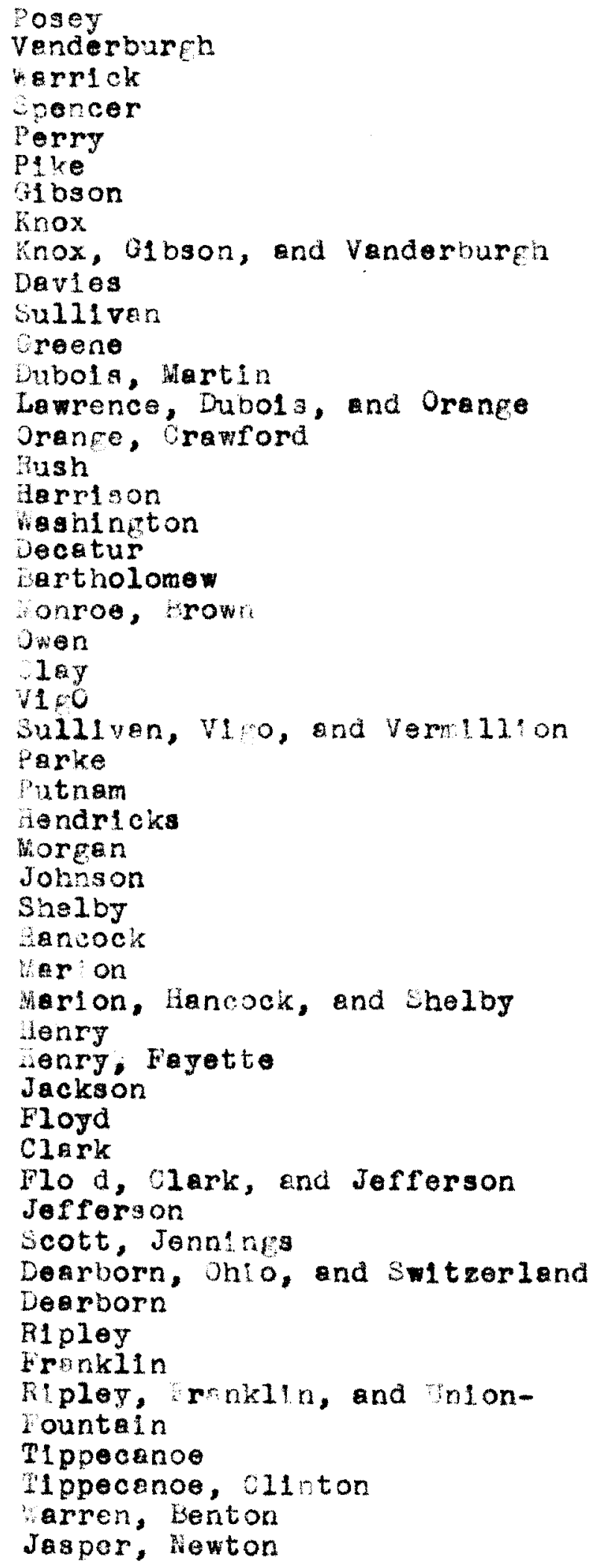


Act of 1085 cont.

RHARSTHIATTVS

Yhite, pulaskl

Carroll

Cass

itami

Casa, hiemi

Wabash

Hantingtion

iols

tryne

fandolph

Delsware

Adems, Jay

Adrms; Jey, and lackford

Grent

adison

enilton

ipton

owerd

coone

clinton

hont fomery

rontromery, Putnam, and loy

A110in

Allen, Huntington

Whitieg

Fulton

Le ke

Porter

Juporte

Leporte, Sterke, end Puleskl

arshali

St. Joseph

lkhart

tosclusko-

nots

LeKa1b

ikhart, Kosclusko, Noble, Dekalb

Lacrane

stouben

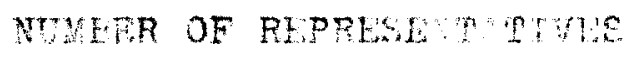

1

1

1

1

1

1.

1

1

2

1

1

1

1

1

1

1

1

1

1

1

$\frac{1}{2}$

1

1

1

1

1

1

1

2

1

1

1

1

1 
An Act to $f$ ix the nuber of senators and Representstives to tho coneral Assembly witin this state. Fassed notwithstanding the Governor's veto herch $5,1891$.

SEMATOKS

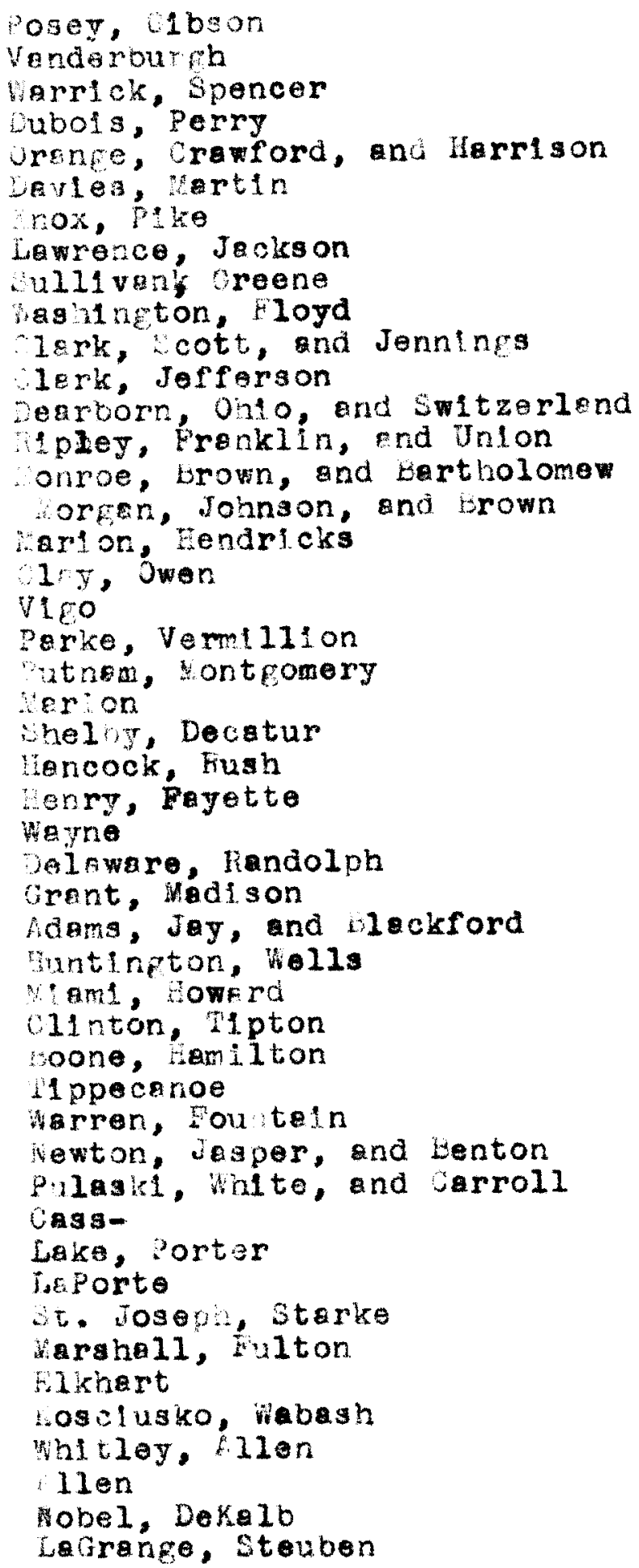

NWBER OF SWATORS

$$
\begin{aligned}
& 1 \\
& 1 \\
& 1 \\
& 1 \\
& 1 \\
& 1 \\
& 1 \\
& 1 \\
& 1 \\
& 1 \\
& 1 \\
& 1 \\
& 1 \\
& 1 \\
& 1 \\
& 1 \\
& 1 \\
& 1 \\
& 1 \\
& 1 \\
& 1 \\
& 3 \\
& 1 \\
& 1 \\
& 1 \\
& 1 \\
& 1 \\
& 1 \\
& 1 \\
& 1 \\
& 1 \\
& 1 \\
& 1 \\
& 1 \\
& 1 \\
& 1 \\
& 1 \\
& 1 \\
& 1 \\
& 1 \\
& 1 \\
& 1 \\
& 1 \\
& 1 \\
& 1 \\
& 1 \\
& 1 \\
& 1
\end{aligned}
$$


Act of 1891 cont.

REP'DSEYTATYTS

NTMBER OF TFERESENATIVES

Venderbureh, libson, and knox

Posey

Gibson

Vander arih

is arrick

Spencer

Porry

Krox

Pike

Oreene

Davies

Lubols, hartin

Lawrence, Orenge, and Lubols

arrison

loyd

Floyd, Harrison, and crawford

Wos 1 neton

Jacks on

lark

Clark, soott, nd Jennings

Jefferson

Aipley

Dearborn

Cesrborn, Ohion and Switzerland

rlpley, Franklin, and Jnion

Irenkiln

Decatur

Bertholomew

Lonroe, brown

Johnson

worean

iven

utnem

Lendrlcks

Sullivan

ley

$\forall 1,0$

Perke

Sullivan, igo, and Vermillion

Hontzomery

Fountein

Wontgomery, Putnem, and clay

Narion

Marion, Shelby

Kedison

Inancock

Shelby

Fush

tenry

wano, Feyette

mayno

Kendolph 
Act of $19 \mathrm{I}$ cont.

$$
\text { KEOSESTATHVE }
$$

Delawere

Hemilton

toone

ilator

Iiption

clinton, lptor, and acis on Lowara

lippocanoo

Lenton, Merren

Leke

gorter

ewton, Jaspor

ulaski, white

carroll

ass

Fulton

coso, M1 Bmi

स $18 \mathrm{mi}$

abas b

vuntington

Tis

Crent:

Adems, Jay

Adams, Jay, blackford

flien

indtaly

Leralo

noble.

Steuber

Lacrang

Ikhort

Ikhart, Kosclusko

Karshal

st. Joseph

Leporte

Leporte, Strice

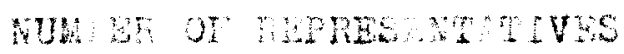

1

1

1

1

1

1

1

2

1

1

1

1

1

1

1

1

1

1

1

1

1

1

3

1

1

1

1

1

1

1

1

2

1 
An Act to $f x$ the number of senators end hepresentstives to the Conerel Assembly whin this State. Approved Gares 4 , 1.53.

$$
\text { STN MORS }
$$

Poser, Gloson

Tonderburgh

arrick, Spencer

Dubols, Perry

Urenee, Crawford, and ararizon

cevios, artin

rnox, pise

Lewrence, jeckson

sullivan, Greone

coshifeton, Floy

lerk, cott, and Jennines

lark, Jefferson

Derborn, onlo, and switzerland

ipley, Irenklir, end unlon

sorroe, Erown, end Bertholomew

torfer, Johns on

Hertor, Hendricks

lay, uwen

ilso

Parke, Vermilis on

utnem, wont corery

erion

helby, Decetur

Aarcock, Fusi

Aenry, Fayetto

neyne

Lelewere, frndolph

erent, Nediaon

tems, Jay, tackford

iuntingtor, olls

Haml, Lowerd

ilnton, Tipton

Loone, lemilton

Tippecanoe

liar on, Fountain

lewton, Jesper, end Lenton

rulaskl, White, and Carroll

cess

Lake, Porter

Laporte

ct. Joseph

varshall, Multon

Likhst

Kosciusko, habash

mhtley, fiome

Allor:

Allen, lekalb

Lacrange, Stauben
NUWBER OF SFYAORS

\author{
1
}

1

1

1

1

1

1

1

$\frac{1}{1}$ 
not of 1893 cont.

$$
\text { PUP ESHATIVS }
$$

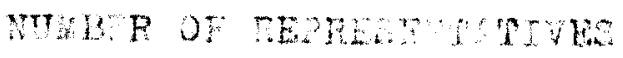

Venderburnh, lbsun, Knox

rosey

Alowor.

Vanderbureh

Gareich

sencer

ierry

inox

is 30

traenc

tavLos

waol 3 , hartin, Orange, and Lawrence arrian

loyd

rawrord, Harrison, and Floyd

asingeton

Jackson

clark

soott, clark, and Jennings

Jofferson

lifpley

Dearborn

Seerborn, onto, and switzerlend

Ipley, Frentilin, and Union

Franizin

Decotur.

Eartholomow

wonroe, trom

Sohnson

orent

Jwer

Putnom

condrioks

willven

Leborte, sterixo

or nt

Iny

Vi:0

Parke

Sullivark Viso, and Vermillion

nontromery

fountain

sontemery, utnam, and ciey

tarion

yr on, sheloy

kad sor

Aencocis

sheloy

sush

Nanry

ineyre, fayot to

rayno

1

1

1

1

1

1

1

1

1

2

1

1

1

1

1

1

1

1

1

1

$\frac{1}{1}$

1

1

1

$I$

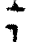

1

1

I

$\frac{1}{1}$

1

1

$\frac{1}{1}$

1

1

6

1

1

1

1

1

1

1 
fet of 1993 cont.

RUPRESEP TIVES

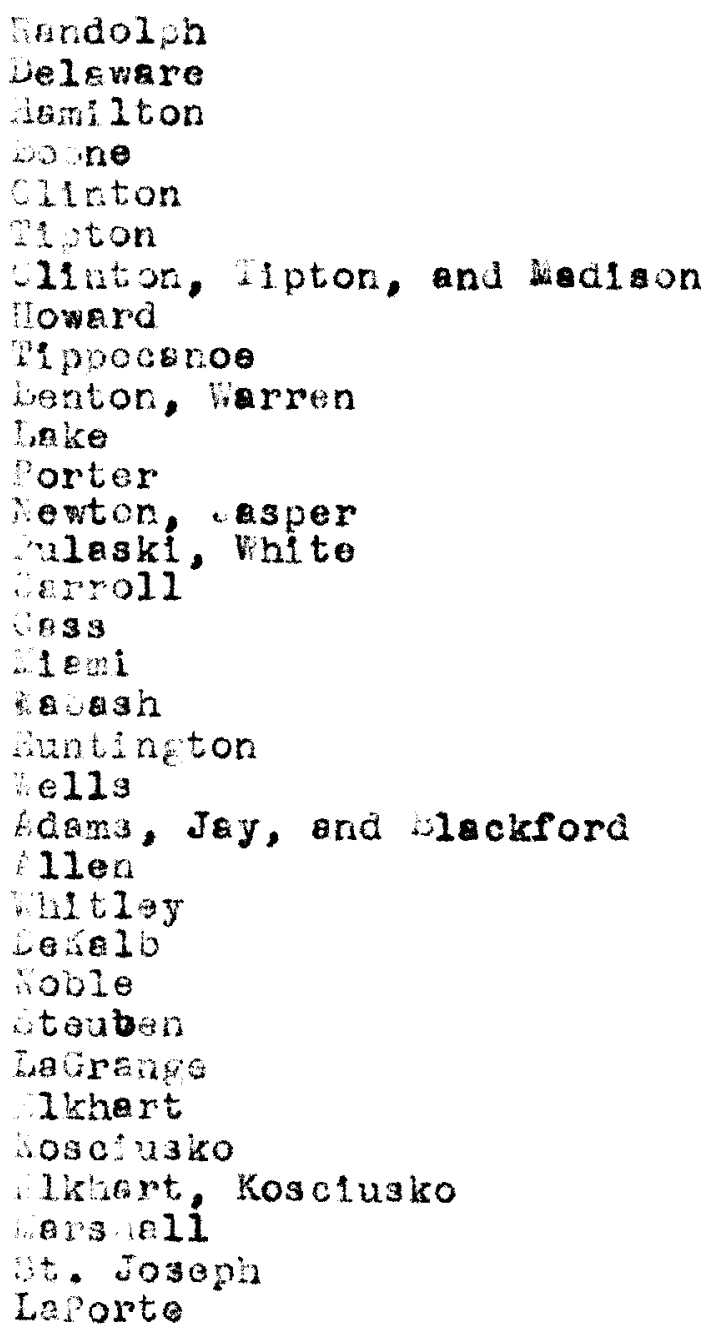

WULW OF FUPRESENAT VIS

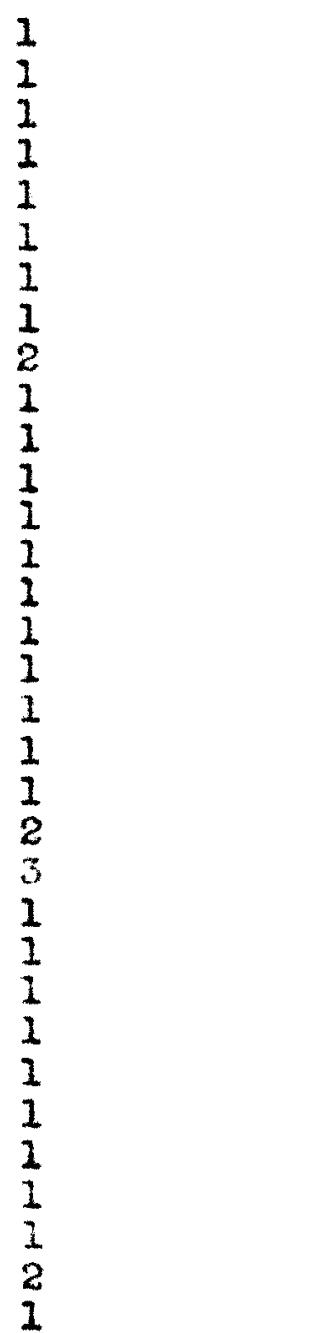


An Act to repeal an Act entitled (An fet to $f^{\prime} \mathrm{x}$ the number of enc ors end Representatives to the Coneral Assenbly of the state of Inden and to sport on the same emong the several countios of the state and to repeel all lavs inconflict therewlth. Passed over the Tovernor's vato harch $5,1895$.

in Act to fix the number of Senetors end Fepresentetives to the cieneral Assembly of this state. Passod over tho overnor's veto Herch $5,1895$.

SEATOES

Poser, closon

vorderburgh

arrick, pencer

Whe, knox

Lubois, Crewford, and Forry

Cavies, lartin, and Orarige

Verrison, Flogd

clerk, wesingen

sott, Jerrines, and Lecatur

Desporn, ont ond switzerland

1piog, Jefferson

Frentín, Pajette, and unton

Fush, Sheloy

Jolnaon, Norgan

tertbolomew, Jeckson

trow, konre, and Lawrence

creere, bulliven

cloy, Uwen

VI

Vermillion, lount"in, and farren

Tertion

tancock, lienry

พreyne

Fanuolph, Lelawere, and Hadison

Simliton, Ripton

Ippentono tone, and Montgomery

ienton, Newton, Jasper, wh1 te

Loward, Carroli

ass, Pulask:

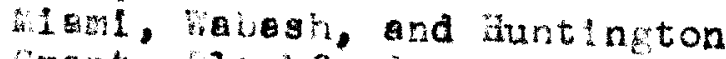

crant, lackrór

Jay, $A d$ rs

Silen

lilen, elis

Dersele, stouben

Leornicio, roble

MUEERS OF SWROTE

1

1

1

1

1

1

1

1

1

1

1

1

1

1

1

1

1 
Act of 1855 sont.

SENADOS

Loactusito, at tley

Sikhert

st. Joseph

2.rsino 11, inl on

Leporta, etarke

Leke, rtes

orise, ptusin

erton, hendroks

HERLEVATIVES

Soser

ibson

Venderburgh

warick

sponcer

Hrox

: $k$, vandorourgh, and Gibson

Davies

habols, Krox, end Lavies

Fervy, Crewford, and Orane

isoritson

Floya

clark

oninton, iloya

jefigren

witzerland, lark, and Jefferson

Jenniners, Scott

Jeckson:

Rislov, ondo

Hearboen, rrankin

Lecating

inctholomen

roun, Johnson, and Jorgen

Lonroe, Lawrerce, and Hartin

creeno

SuIIIvan

bley

Gisy, owen

iutnam

$v_{1}, 0$

Veo, Vermi11:or

Parke

Dencirioks

inar on

whelby, warton

Hen $x y$

Hencock, Henry

Fush

Fayotte, Union

Wevne

Fond $1 p$ i

Dele ware

teckford, Lelaware, end Kandolph Jey

fidison
NUEER OH SWDAOM.

1

$i$

1

1

i

1.

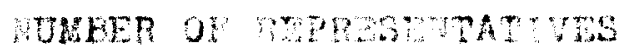

1

$\frac{1}{2}$

1

$\frac{1}{3}$

I

I

1

2

1

1

1

1

1

1

1

1

1

1

2

2

1

1

1

1

2

1

1

I

6

1

1

1

1

1

2

1

1

1 
Aot of 1995 cont.

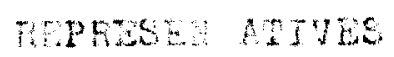

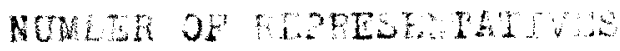

in at

Cowera

iredist, Crent, end Howard

irmiton

lewiton, ipton

$12 \tan$

Loore

bont omery

1.nton, koone, and tont ponery

iountain

Lppeosroe

Erren, Eerton

vouton, Jaspor

ulasks, white

Carroll

Cres:

ismi.

Abesh

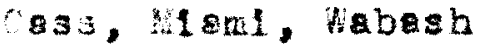

motinetor

cuntingtor, nint $10 y$

Sel1s

Adaris

A11en

Letialo

theubon, Doralo

. 0010

coble, Lotrenge

Skhart

Losciusko

trgas 11

$\therefore t$.joseph

Hont conory

1

1

1

1

1

1

1

Leporte

worte, Sterke

\section{Leke}


An tot to fix the nurber of senators ond liopresentetives to the Coneral Asambly within this tate. Approved lebruary $25,1097$.

$$
\sin \cos
$$

NUMER Or S nTore

roser, sibon

Fnde bureb

terderburgh, ferrick, and Plke

epencer, perry, and crawford

livbola, Devies

arrion, $10 \% \mathrm{~d}$

asulinton, Jacks on

lerk, cott, Jennina

Sefriogn, Ipley, and Switzerland

renkl , unlo, and Deerborr

sartiolomew, Decetur

resno, hor roo, trown

setin, urenge, Lawronce

rimox, sulliven

1,0

1,0, Frke, Vernillion

$10 y$, owea

watan, for beomery

sandroks, coone

$x+3 \pi$

aron, woran

Tohnson, Skelby

cedson

edjson, Fush, and liancock

lerry, foyette, Union

ane

Peloloh, Iay

Cowere

amilton, ipton

rent

Grant, *ells, and blackrord

Al1en

Aller, hatis

untington, whitley

wabash, Hiton

Hom: owara

Iinton, Cerroll

ippecanoe

Tountan, , warren, and benton

howton, Jasuery end uhite

rass, Pulasks

Leve, Porter

Leporte, Starke

t. Joseph

Nelsholl, Kosclusko

Uirhart

Iocrange, noblo

Steubar, Kalb

1

1

1

1

1

1

1

1

1

1

1

1

1

1

1

1

3

1

1

1

1

1

1

1

1

1

1

1

1

1

1

1

1

1 
Act of 1 egr cont.

\section{REPREETI:TYS}

iosey

Jandorburgi

losor, Rrox, and Vanderurgh anglok

tponcer

Gery, Crawford

arison

Hord

tor

Ioy, lark, and washinfton

cott, Jenrings

serferson

bio, seltzalend

fer roor

I. ploy

Jeckson

Lowretice

artin, orange

inools, Dike

sules

Ullivar

creene

otroe, Lrown

Lertholomew

ocatin $r$

rentiti, Un: on

vabl

we 1 by

vohnion

oren

$10 \%$

1ey, owen

1100

To, Vemiliton

enco

otnsm

ondricks

varion

arion, Hancock

Banry

tayo

aryno, iayet to

randolish

Jey

Randslph, Jay, lackford

belawaro

mad1son

lentiton

bone

nont onery

fodison, Hen11ton, foore, isontgomery

Lourtain

T1ppecanoe

11 ppecenoe, Harrer

dinton

cilnton, lipton

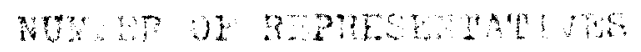

1

2

1

1

1

1

1

1

1

1

1

1

1

1

1

1

1

1

1

$\frac{1}{1}$

2

1

1

1

$\frac{1}{1}$

1

1

2

2

1

1

1

1

1

1

1

1 
Act of 1897 eont.

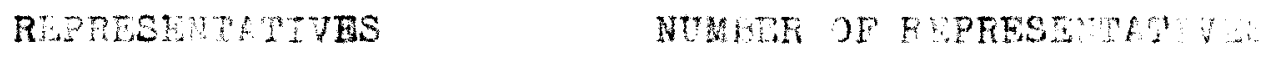

arroll

atat

Woard, Grnt, hismi, wabash, iuntinfton

ielis

liams

Alen

Cosclusko

ros isko, whtloy

Coss

us?, Fulton

bits, ins

senton, lowton

¿\&ke

Jasper, Lake

orter

salorte

Letorta, torko

arsoli

t. Jogoph

inhert

obla

alelb

wereng, teuben 
Sn tet to fic the nuaver of senotors arc reprosentatives

co the oneral Asembly within this stete. Approved

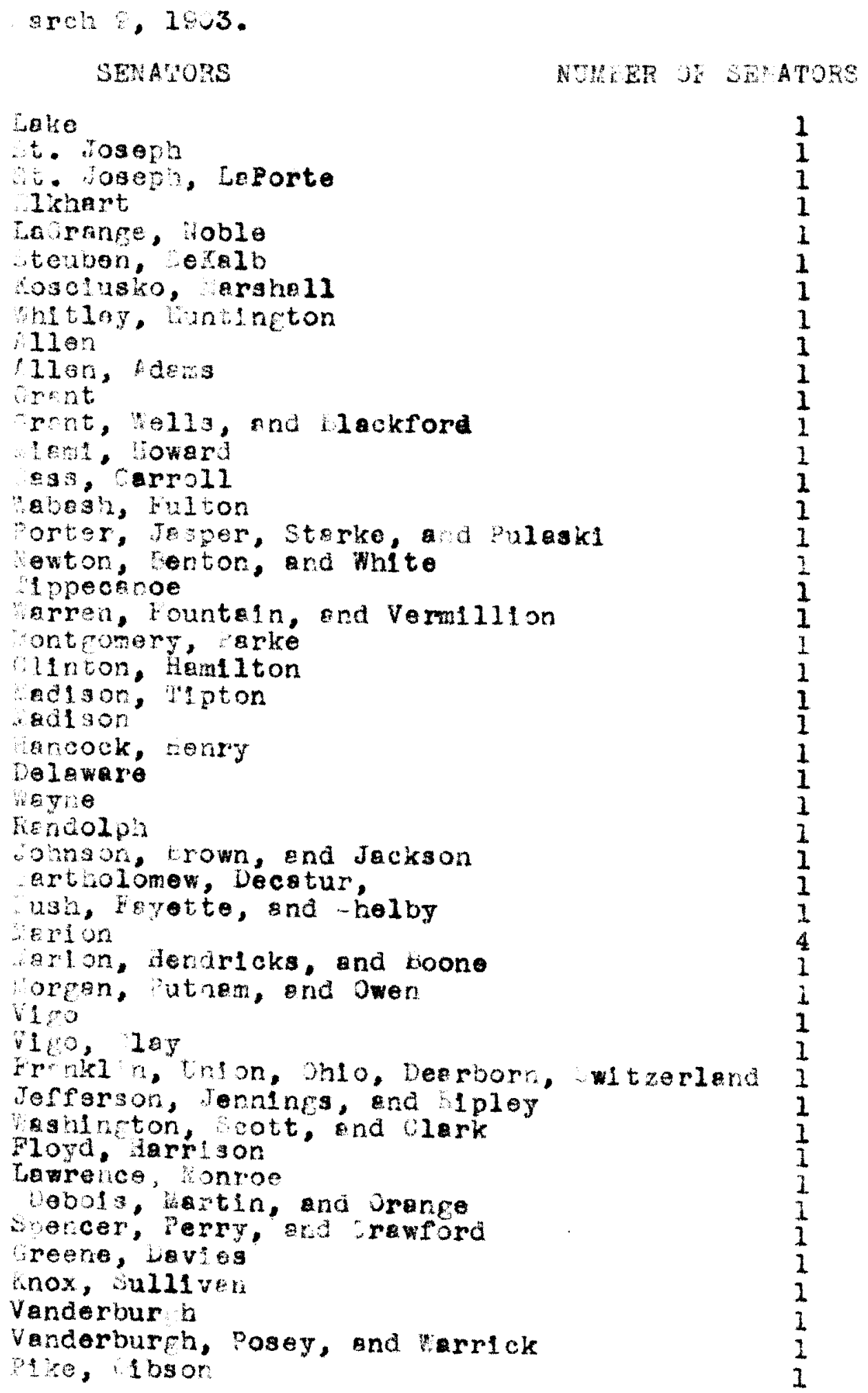




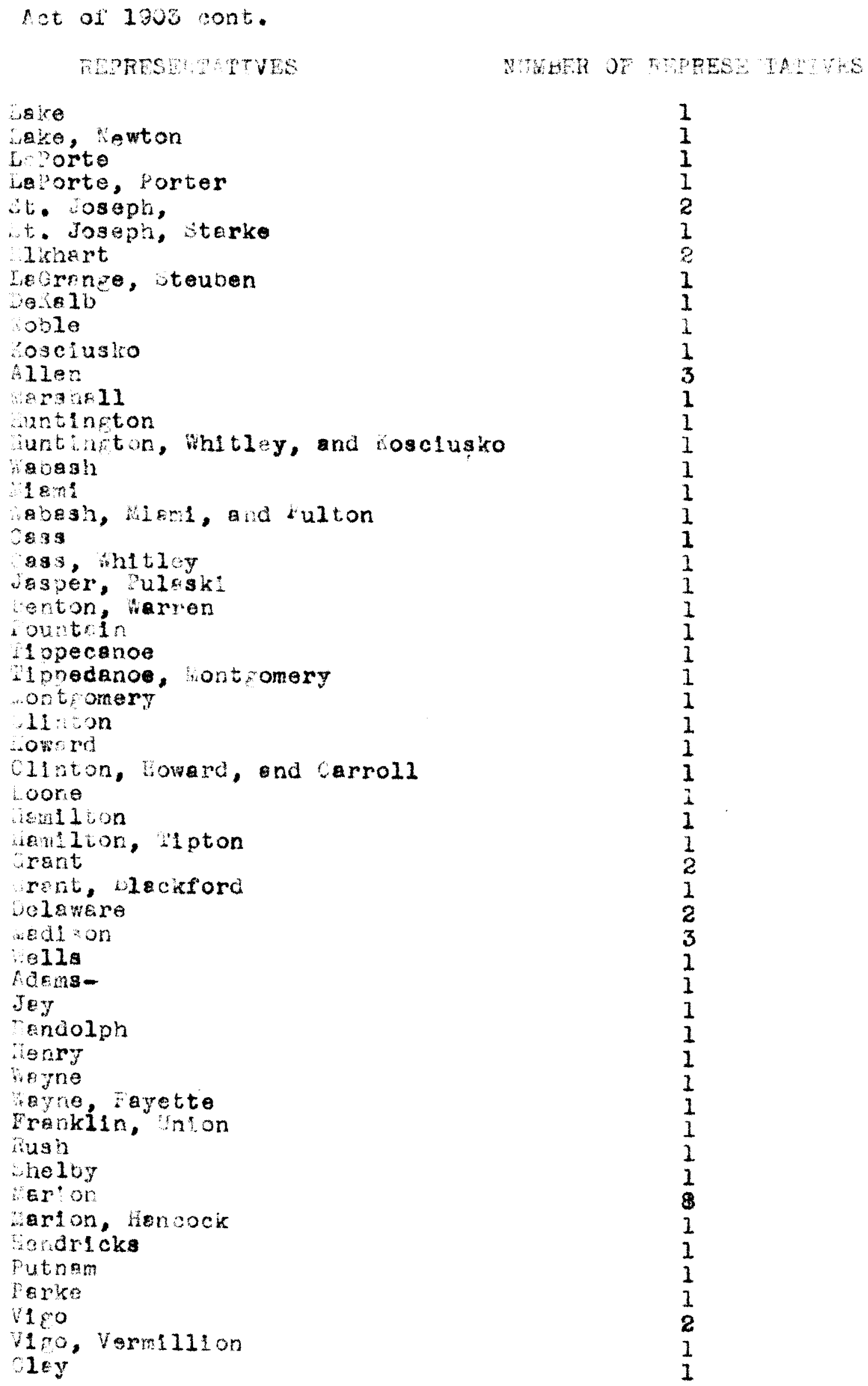




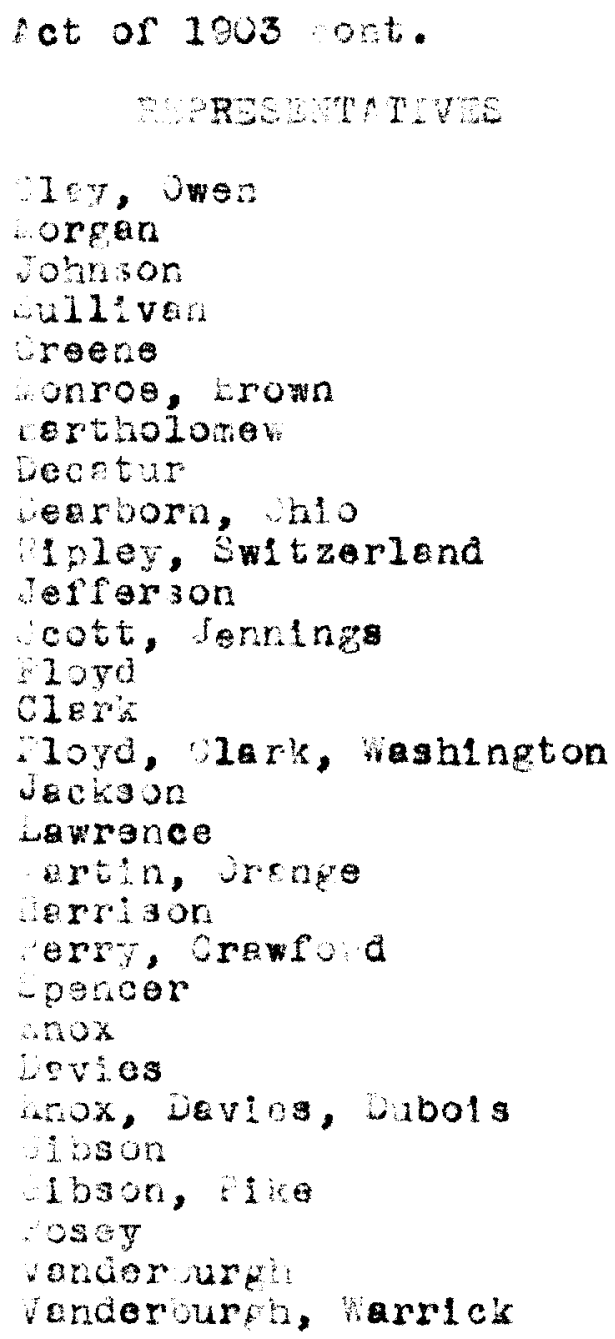


An fot to $f i x$ the mumber of senators and hepresentatives to the leneral Assenbly win this stato. Lpproved rrob 2, 1205 .

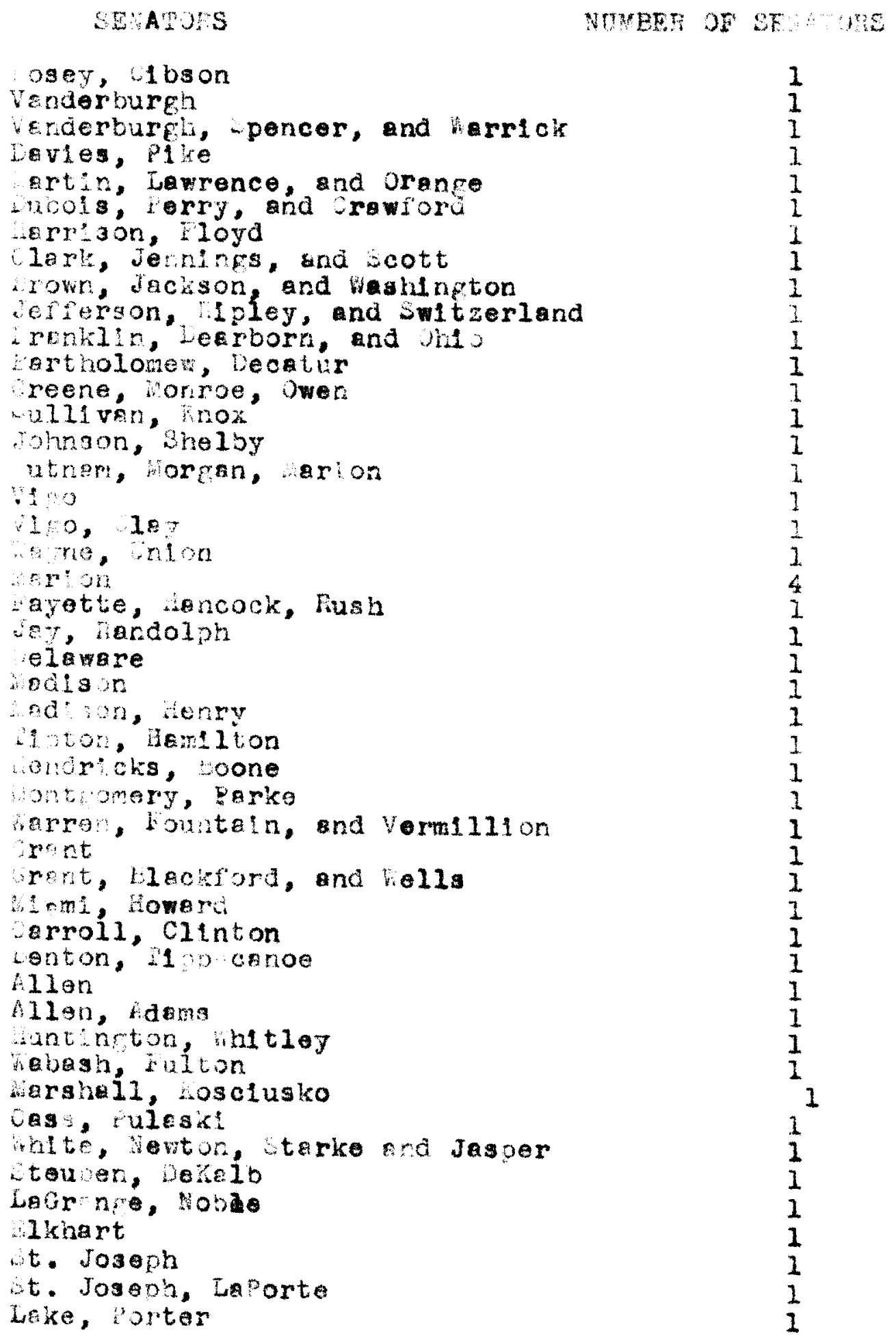


Act of 1805 cont.

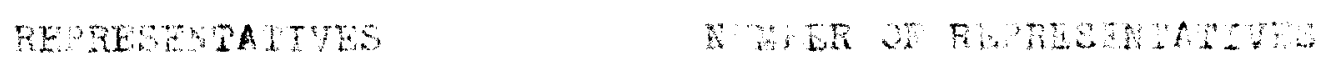

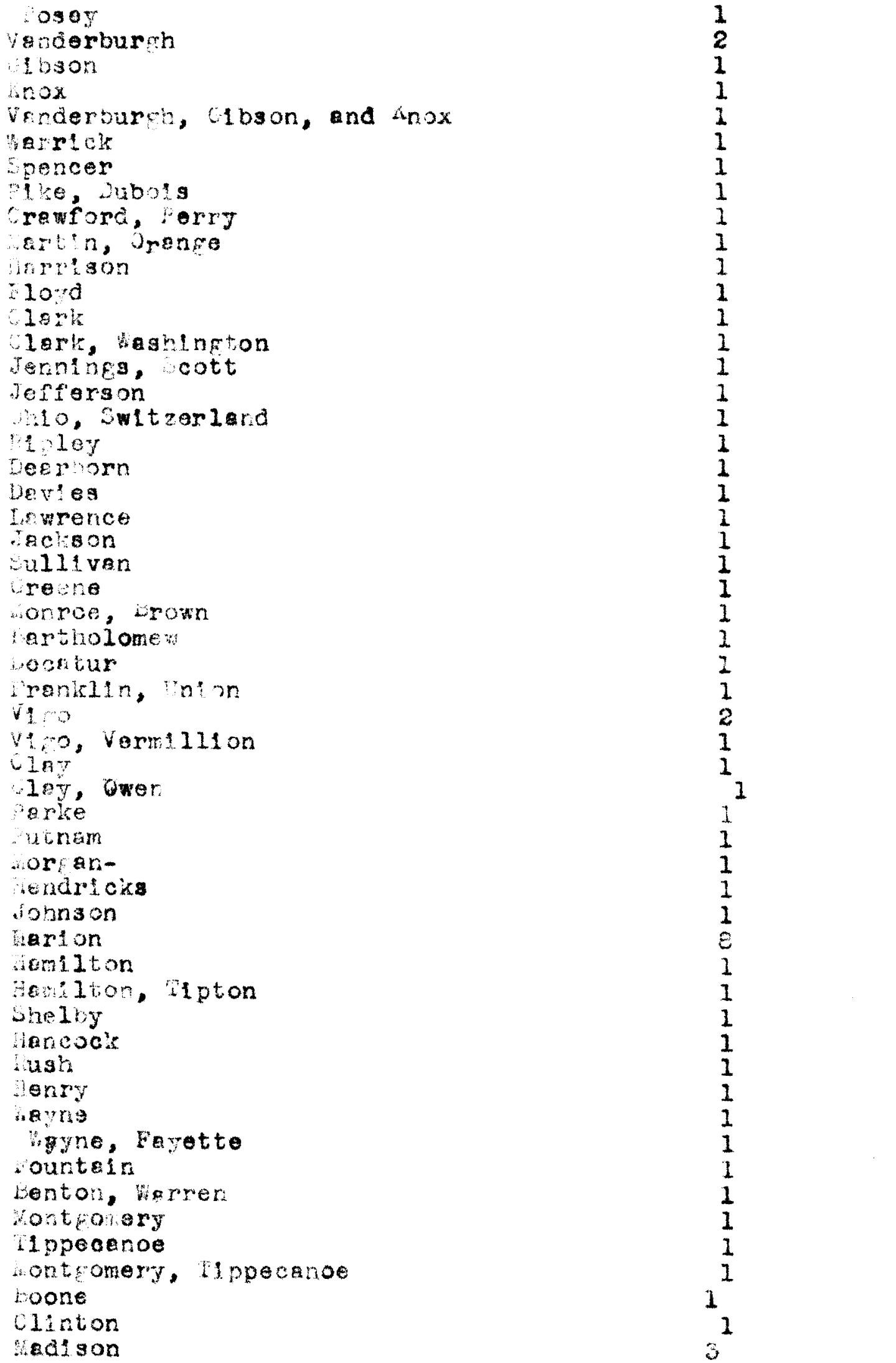




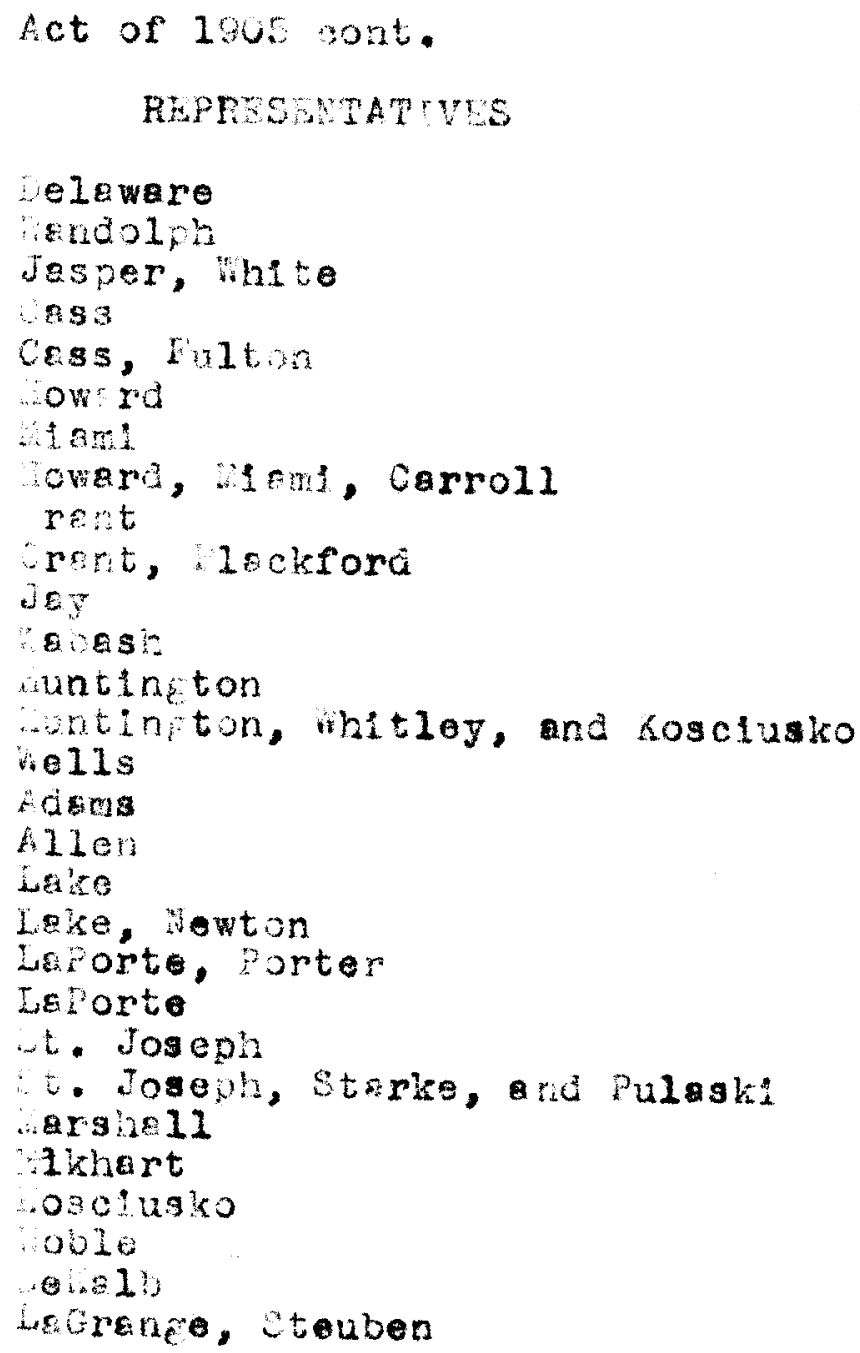

2

1

1

1

1

1

1

1.

2

1

1

1

1

1

1

1

3

1

1

1

2

1

3

2

$\frac{1}{1}$

1 


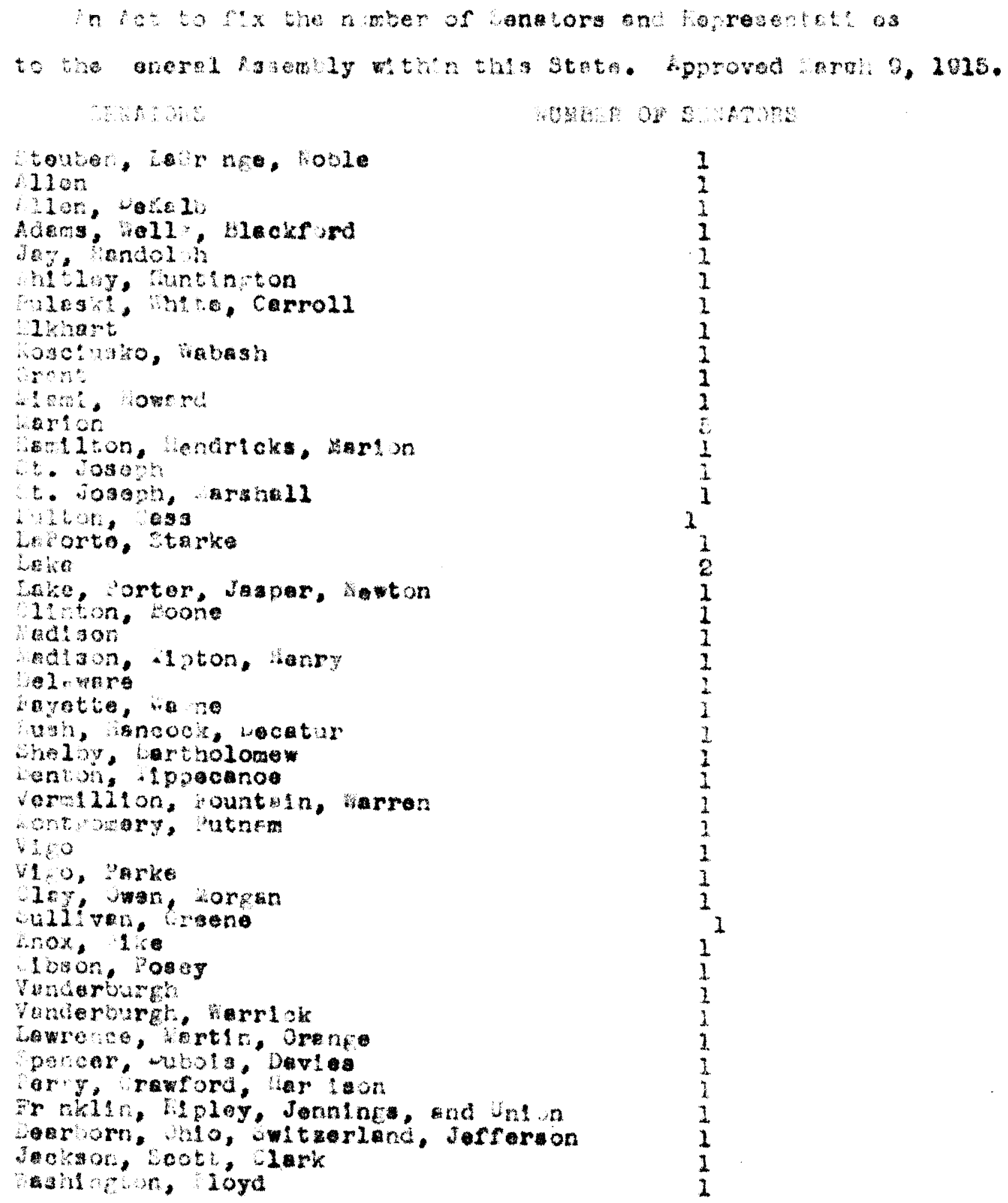


Act or 1915 cont.

FESTELITATHES

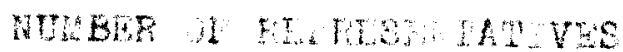

Tisson

osey

varderburmb

Enderburih, Harrick

ervo, spencor

$\operatorname{crox}$

Saox, plike

Gilliver

ireene

revies, wrtin

ionpos, wrown

upols, vrenge

Lawrence

Esinton, Crawford

loya, ariaon

$10 y d$

In?

weokon

cott, Jefferson

dentholomey

ectur, Jenains

blez, wotzerlenc

verrore, oklo

erion

encock

Ireklin, reyetto

30134

16nery

T.t.

ano

otre, Talo:

Johnson

1. $y$

V1, 0

Nontomery

porgáa

terdricks

Vermilion

Delaware

Rendolph

JeY

A dams

Nells, blackford

1

Ippecanoo

poone

winton

Jentition

sedison

Ipton, Madison

novere

t110n

Hler, hetoy

Wo: 10

Jolkalb 
hot of 1 is cont.

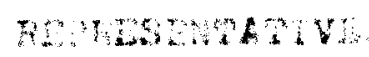

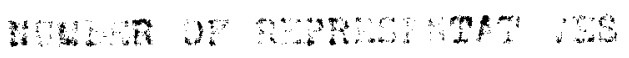

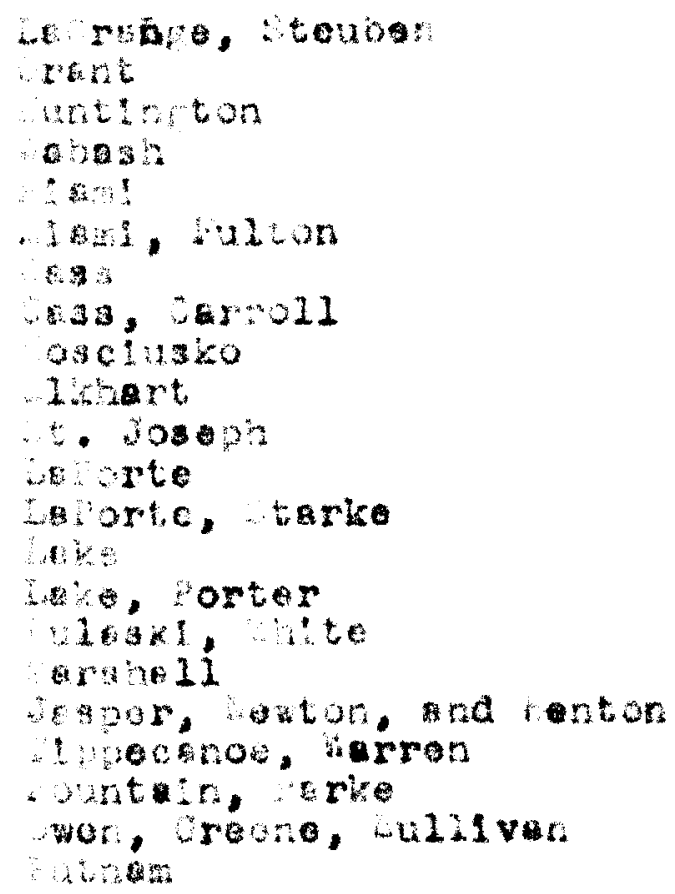


$r$ lit to flix the number of cenetors and hepresentatlves

to the ceneral issambly within this State. Approved ereh 5, 1921.

$$
\text { SAMAOFS NWHER OF SWATORS }
$$

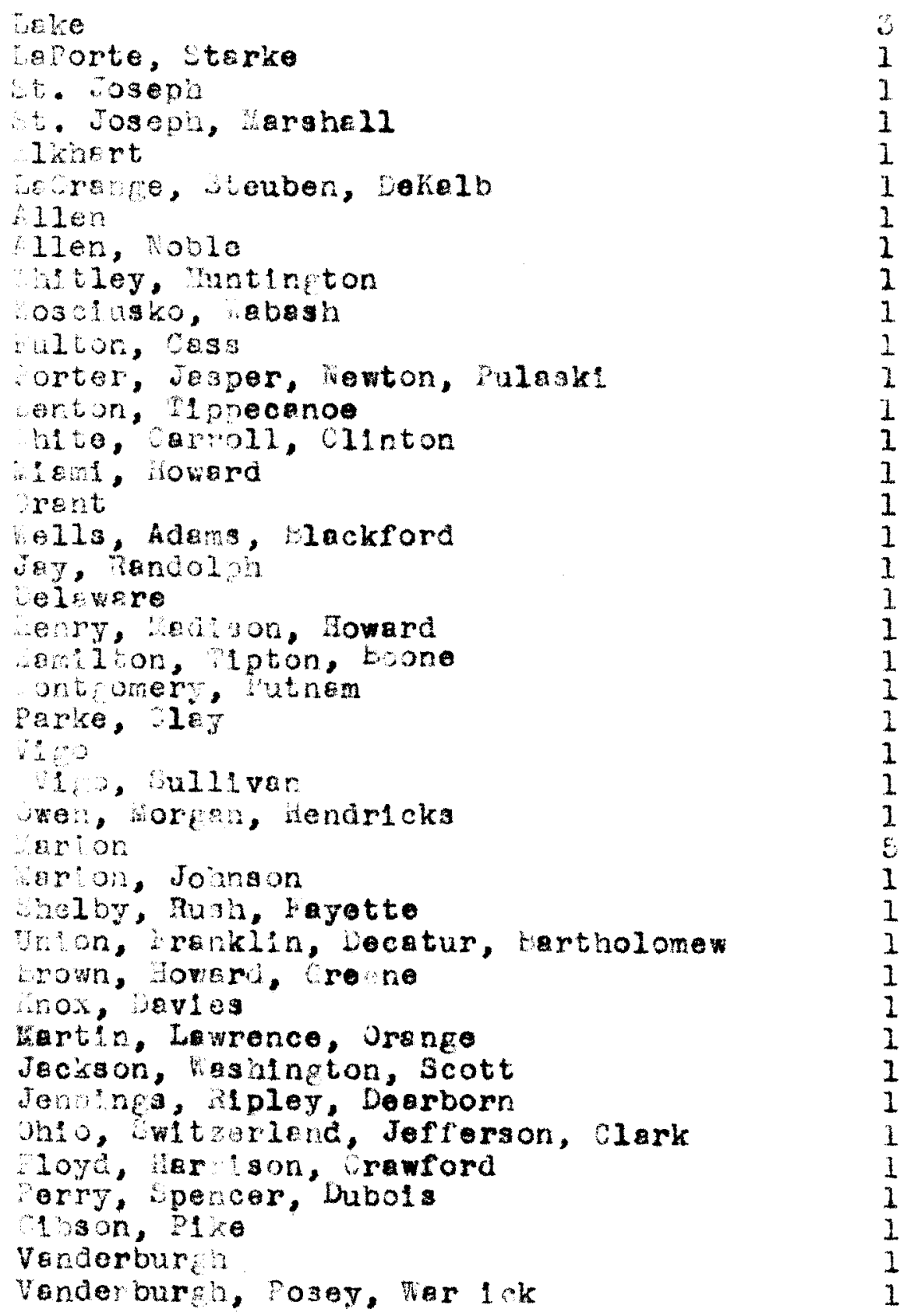


let of 1921 eoat.

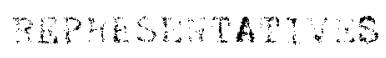

$$
\text { 3...... }
$$

and

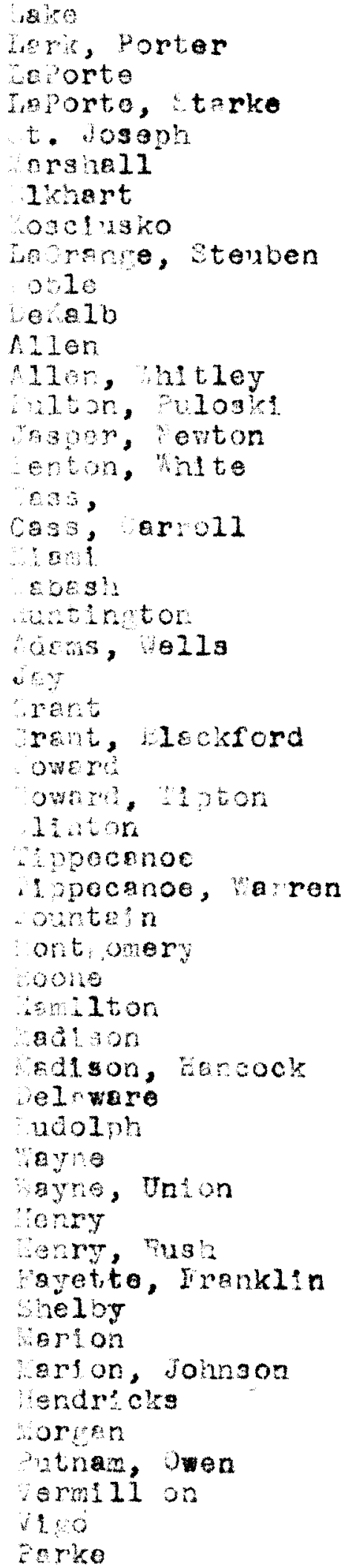


let of 1921 cont.

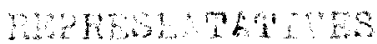

NTHABA OP REPRES?

104

1

w11tven

1

re ne

. or ros

tertiolones

secetur, werntas

Rosrborn, Onio

Ipley, witzoriand

tofferaon, :cott

lents

1070

werrerico

freason, Exowh

reslarteon, Jenge

reviond, arison

Ext, Lubols,

corre, choncer

avies

mox

mox, like

2030 n

indorburin, josey, warlek 
Er BTT OORAPEX 


\section{BI BLTOQRAPEY}

Boolan

Gbandzer, Jilian AlTin Oarroll, Roprecentation in Virinse. Beltimores the John koptin Trose.

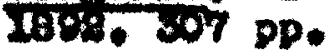

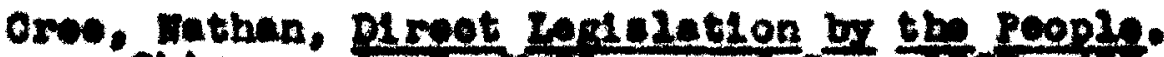

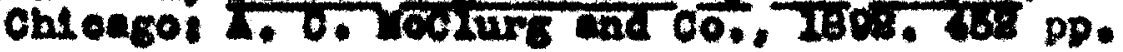

Bearoy, Logan, A Histor of Indieng-Vol. I. Dayton,

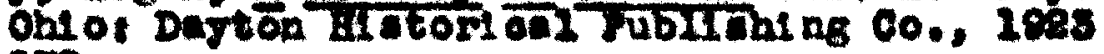
$872 \mathrm{pp}$.

Ford, Bonry Jonos, Representati re covernent. Wo

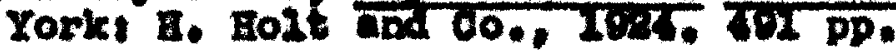

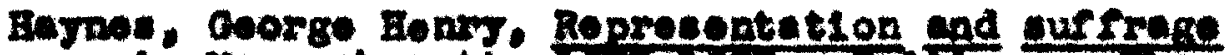

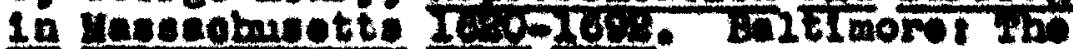

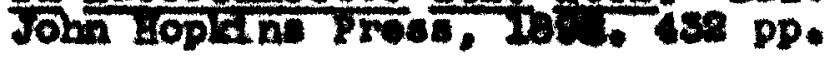

Robertson, J. X.. Eleotores justiea, a arwor of

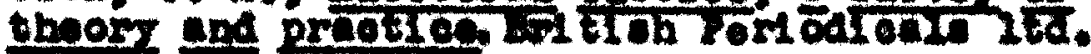
I0sI.

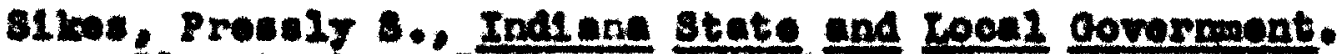
Blocul agton, Indiana Frinot pha Frose. Ino. IFo.

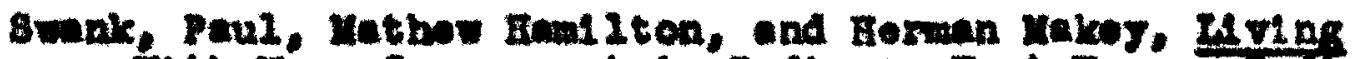
Ith Your Govertment in Indere, Fort Enyo. Indtanat

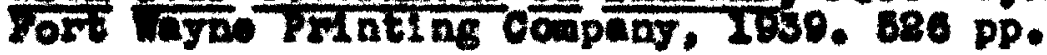

\section{Coneral}

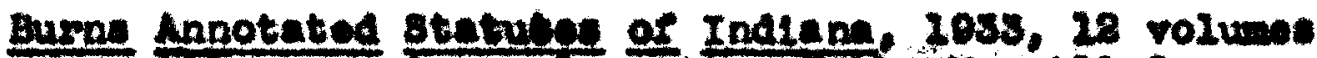

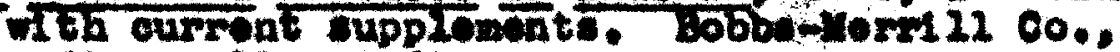
Indianapolis. Inds and.

Conatitution of Indiane and of tbe Unitod states.

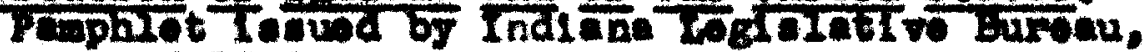
Rovised 1058.

Lote of the cenerel Aecobly, seorotury of state. 
Rogular state Publioati on

Indiana Historloal pulletin (monthly) Historleal Bürocu.

Reports of Appeliate Court, secretary or state

Roporte of supreme Court, Sooretary of state

Roster of state and 20001 orficers (Anmualig) Di vial on of Tocounting and Stetistion.

Statiotioal Roport (Annually) Dirision of Accountiag and stetiatior.

Yoar Book (Annuelly) Divial on of Accounting and Statiation. 